NBER WORKING PAPER SERIES

\title{
IS IT WHO YOU ARE OR WHERE YOU LIVE? RESIDENTIAL SEGREGATION AND RACIAL GAPS IN CHILDHOOD ASTHMA
}

\author{
Diane Alexander \\ Janet Currie \\ Working Paper 23622 \\ http://www.nber.org/papers/w23622 \\ NATIONAL BUREAU OF ECONOMIC RESEARCH \\ 1050 Massachusetts Avenue \\ Cambridge, MA 02138 \\ July 2017
}

We thank the staff at the New Jersey Department of Health and Senior Services for their assistance in accessing the data used in this paper, and the Center for Health and Wellbeing for financial support. We are grateful to Sharada Dharmasankar, who provided excellent research assistance. All views expressed are those of the authors and cannot be attributed to the Federal Reserve Bank of Chicago, the Federal Reserve System, the New Jersey Dept. of Health and Senior Services, any of its employees, or the National Bureau of Economic Research.

NBER working papers are circulated for discussion and comment purposes. They have not been peer-reviewed or been subject to the review by the NBER Board of Directors that accompanies official NBER publications.

(C) 2017 by Diane Alexander and Janet Currie. All rights reserved. Short sections of text, not to exceed two paragraphs, may be quoted without explicit permission provided that full credit, including (๑) notice, is given to the source. 
Is It Who You Are or Where You Live? Residential Segregation and Racial Gaps in Childhood Asthma

Diane Alexander and Janet Currie

NBER Working Paper No. 23622

July 2017

JEL No. I14,R23

\begin{abstract}
Higher asthma rates are one of the more obvious ways that health inequalities between African American and other children are manifested beginning in early childhood. In 2010, black asthma rates were double non-black rates. Some but not all of this difference can be explained by factors such as a higher incidence of low birth weight (LBW) among blacks; however, even conditional on LBW, blacks have a higher incidence of asthma than others. Using a unique data set based on the health records of all children born in New Jersey between 2006 and 2010, we show that when we split the data by whether or not children live in a "black" zip code, this racial difference in the incidence of asthma among LBW children entirely disappears. All LBW children in these zip codes, regardless of race, have a higher incidence of asthma. Our results point to the importance of residential segregation and neighborhoods in explaining persistent racial health disparities.
\end{abstract}

Diane Alexander

Federal Reserve Bank of Chicago

11 th floor

230 S. LaSalle St.

Chicago, IL 60604

dalexander@ frbchi.org

Janet Currie

Department of Economics

Center for Health and Wellbeing

185A Julis Romo Rabinowitz Building

Princeton University

Princeton, NJ 08544

and NBER

jcurrie@ princeton.edu 


\section{Introduction}

Higher asthma rates are one of the more obvious ways that health inequalities between African American and other children are manifested beginning in early childhood. Asthma is one of the most common childhood chronic conditions, accounting for approximately 774,000 visits to the emergency room in 2009 (Newacheck and Halfon, 2000; American Lung Association, 2012) and affecting approximately one in every 11 children (Akinbami et al, 2009). Data from the National Health Interview Survey suggest that rates are much higher among African-Americans: in 2010, black asthma rates were double non-black rates (Akinbami et al, 2014). Some observers even describe "being black" as a risk factor for asthma (WebMD, 2016; Mayo Clinic, 2016).

Although many factors including income, birth weight, preventive care, and urban residence have been shown to be related to asthma prevalence, it has proven difficult to fully account for the gap between African-American and other children. For example, McDaniel, Paxson and Waldfogel (2006) find that they are unable to explain the racial disparity with the detailed child and family characteristics available in the National Health Interview Survey. They comment that "Many studies have documented the racial gap in asthma prevalence, but few have explained it."

This paper asks whether what is manifested as a racial difference in asthma prevalence is actually an effect of neighborhoods rather than an effect of race per se. This distinction is important because unlike race, it is possible to change neighborhoods either by finding and remediating the hazards that are causing higher asthma prevalence or by helping vulnerable children to move. Moreover, if the underlying factor is actually residential location rather than race, then it will affect all children in a neighborhood regardless of race, meaning that an exclusive focus on race as a risk factor may cause some affected children to be overlooked.

Using a unique data set based on the health records of all children born in New Jersey between 2006 and 2010, we explore the roles of race, birth weight, and residential location in explaining the incidence of emergency room visits for asthma in early childhood. In addition 
to the large scale of our data set, we are able to compare siblings born to the same mother in order to rule out other unobserved characteristics of mothers as potential confounders, and to examine a large sample of non-black children who live in the same neighborhoods where most African-Americans in our sample reside.

Consistent with previous research, we find that low birth weight (LBW) children are more likely to have emergency visits for asthma, and that this result holds within families when comparing siblings. Black children are more likely to be LBW, but have significantly more visits for asthma than other children of the same birth weights at all weights, though the gap is more pronounced at lower weights.

Our most surprising result is that the racial difference in asthma prevalence among low birth weight children disappears when we look within the neighborhoods where most AfricanAmerican children live. That is, when we condition on whether a mother lives in a black zip code (defined so that half the children in the sample living in so-called black zip codes were African-American), there is no longer any racial difference in asthma prevalence conditional on birth weight. Put another way, all LBW children---including non-black children---are at much higher risk of asthma if they happen to live one of the New Jersey neighborhoods where the majority of African-American residents live. This result clearly points to the importance of neighborhoods as a key determinant of asthma prevalence in vulnerable LBW children, and suggests that understanding the characteristics of neighborhoods that contribute to asthma prevalence is necessary for addressing racial gaps in children's health status, and for protecting the health of vulnerable LBW children more generally.

The rest of this paper is laid out as follows: In section 2, we discuss the background for our study. Section 3 lays out the data, and section 4 discusses methods. Results appear in section 5, and a discussion and conclusions appear in sections 6 and 7 . 


\section{Background}

African-Americans tend to be in worse health than whites at all ages (Boustan and Margo, 2014), a fact that is reflected both in higher rates of low birth weight and prematurity, and in higher death rates (Currie and Schwandt, 2016). Research over the past ten years has also shown that poor health in childhood is associated with poorer health and other outcomes in adulthood (see Almond, Currie and Duque (2017) for a recent review). For example, Isen, Rossin-Slater and Walker (2017) show that children born in counties that cleaned up their air following passage of the Clean Air Acts of 1970 were more likely to work, had higher education, and had higher earnings as young adults. Thus, it is probable that some of the continuing health disparity between African-Americans and others over the life course has its origins in negative health shocks to early life health, some of which, like pollution exposure in utero and in early childhood, are due to their residential location.

One possible contributor to the racial differential in health is low birth weight (LBW), defined as birth weight less than 2500 grams. African-Americans are twice as likely as others to be LBW and LBW has been shown to have negative effects on a broad range of outcomes. For example, Oreopolous et al. (2008) use a large sample of twins and show that within twin pairs, LBW is associated with higher mortality up to age 17, as well as with lower schooling attainment, and a higher probability of being on welfare. LBW is also associated with a higher incidence of asthma: Research using a large sample of Swedish twins (Ortqvist et al, 2009; Villamor, Iliadou, and Cnattingius, 2009) shows that even within twin pairs, LBW is increases the incidence of asthma. However, as discussed above, within birth weight categories, blacks are more likely to have asthma than others, so LBW by itself cannot be a complete explanation for the racial disparity in asthma; rather, LBW should perhaps be

viewed as a factor that primes children to have asthma in certain circumstances. In this paper, we examine residential location as one such circumstance.

Social scientists have long been interested in the ways that neighborhoods affect people's health. Pickett and Pearl (2001) and Kawachi and Berkman (2003) provide excellent 
reviews of this literature; most studies show evidence of an association between neighborhood characteristics and health outcomes even after controlling for a range of measurable individual and family characteristics. Curtis, Dooley, and Phipps (2004) look specifically at children and show that neighborhood characteristics predict several measures of child well-being conditional on family characteristics. Merkin et al. (2009) argue that the stress associated with living in disadvantaged neighborhoods increases "allostatic load," which in turn leads to a wide range of poorer health outcomes, and find particularly large effects among African-Americans.

Since observational studies are limited in the extent to which they can distinguish between neighborhood effects and the effects of family characteristics common to people living in disadvantaged neighborhoods, data from the Moving to Opportunities (MTO) experiment are of particular interest. The MTO randomly assigned families to a treatment regime that required them to move to lower poverty neighborhoods in order to obtain housing benefits. Surprisingly, research based on the MTO data by Fortson and Sanbonmatsu (2010) and Katz, Kling, and Liebman (2007) concluded that neighborhood characteristics had little effect on children's physical health outcomes, including asthma. ${ }^{1}$

However, the MTO health measures are parent or self-reported which may introduce considerable measurement error relative to the administrative data we use here. Such error would be a particular concern if changing neighborhoods caused people to think about or report their health differently. It is also important to note that while all of the "treated" children in MTO moved to lower poverty neighborhoods, the new neighborhoods were not much less segregated than the old ones. For instance, Katz, Kling, and Liebman (2007) report that the average share minority in the treated group was $82 \%$ after moving. Thus, the MTO experiment leaves open the question of whether children's health can be improved

\footnotetext{
${ }^{1}$ More recently Chetty et al. (2016b) use data from the Moving to Opportunities experiment to show that children who were randomly assigned to a program that led them to live in lower poverty neighborhoods as young children experienced lasting improvements in adult outcomes including education and income. However, the only health outcome available in the tax data they use is disability status, and they do not examine that.
} 
by moving away from heavily segregated neighborhoods.

Jacob, Ludwig and Miller (2013) exploit a "natural experiment" created by the Chicago public housing authority. In 1997, the city opened its housing-voucher wait list for the first time in over ten years. As a result, the authority randomly chose families from a wait list to receive Section 8 housing vouchers; these families were enabled to leave large public housing projects and move anywhere that would accept their vouchers. The authors find suggestive evidence of positive effects of mortality among boys and large negative effects of mortality among girls. However, the standard errors are large which reflects the fact that mortality is a rare outcome; for example among "treated" girls, there was only one death. Thus, this study highlights the potential gains to understanding the health effects of neighborhoods from examining a relatively common health problem like asthma rather than a (thankfully) rare one like mortality. Moreover, like the MTO, the "treated" population in the Jacob, Ludwig and Miller (2013) study generally stayed within segregated neighborhoods.

Research has consistently shown that the U.S. continues to be highly racially segregated, with African-American neighborhoods (on average) suffering higher poverty, lower average educational attainments, higher unemployment, higher exposure to pollution, and other ills (Boustan, 2011). ${ }^{2}$ Thus, black mothers may de facto have less choice about where they live compared to other observationally similar women. It is this continuing residential segregation combined with the unexplained health differential between black and non-black children that makes the concept of a "black" zip code salient for our research.

The preceding discussion makes clear that while there is substantial overlap between poor neighborhoods and black neighborhoods, they are not the same thing. People can move to less poor neighborhoods but remain highly racially segregated, while many non African-Americans reside in poor neighborhoods. Nevertheless, given the overlap between poor and black neighborhoods, the literature on socioeconomic determinants of health is certainly relevant. This is a vast literature but perhaps the key reference with respect to

\footnotetext{
${ }^{2}$ Negative peer effects may also contribute to poor outcomes. See Case and Katz (1991).
} 
child health is Case, Lubotsky, and Paxson (2002) who show that while poor children start life in poorer health than richer ones (by almost any measure), the gap continues to grow as children age. Currie and Stabile (2003) demonstrate that this widening gap occurs because of a higher arrival rate of negative health shocks (such as developing asthma). Condliffe and Link (2008) show further that in the U.S. poor children also recover from each health shock more slowly than rich children.

Chetty et al. (2016a) is one of the few studies to bring together the literature on socioeconomic status and health and the literature on the effects of place on health. Using rich U.S. tax data, they explore the interaction between low household income and residential location in the production of life expectancy. They show that life expectancy for low income individuals varies greatly across commuting zones in the United States. Low income individuals had significantly shorter life expectancy in several cities in the industrial Midwest such as Gary, Detroit, and Cincinnati, and significantly longer life expectancy in New York City, Miami, and Los Angeles. Unfortunately, given that the tax data do not record the race of filers, they are unable to extend their analysis to examine racial differences in health.

Our work contributes to this literature on the health effects of place. We ask whether what is often viewed as a racial difference in asthma prevalence is actually a neighborhood difference in asthma prevalence. This is an important question because unlike race, we can change people's neighborhoods either by identifying the problem and remediating it or by enabling people to move to safer areas. By focusing on a common illness rather than on death, we can conduct our analysis at the zip code level, which is a much finer level of aggregation (and a closer approximation to a neighborhood) than the commuting zone (there are 741 commuting zones in the U.S. compared to roughly 40,000 zip codes). ${ }^{3}$ Moreover, by comparing children born at different birth weights to the same mother, we can isolate the effects of place per se, rather than measuring the effects of place bundled with the

\footnotetext{
${ }^{3}$ Previous work by Nepomnyaschy and Reichman (2006) shows that at the level of the Census tract, the fraction of housing that is renter-occupied and vacancies are predictors of childhood asthma. Unfortunately, we do not have sufficient observations within Census tract to conduct our analysis, so we use the zip code.
} 
characteristics of mothers that cause them to locate in a particular place.

\section{Data}

Our sample is the cohort of all children born to mothers residing in New Jersey between 2006 and 2010. ${ }^{4}$ The sample is constructed by merging information from electronic birth records filed with the state government to hospital records covering every visit to a hospital emergency room (ER) from 2006 to 2012. These data are then collapsed, so that every child is represented by one observation. The information on the birth certificate is used to link siblings via identifying information about their mothers. This matching process was conducted in Trenton at the Department of Health and Senior Services, and these data were then de-identified on site. Below, we discussion data construction in further detail.

New Jersey electronic birth records include detailed information about infants and mothers. For the mother, we have her name, as well as information about her race, age, education, marital status, date of birth, residence at the time of the child's birth, and whether she smoked during the pregnancy. For the children, we know birth weight, gender, and birth order (including whether it was a multiple birth).

We combine the birth records with information about ER visits from New Jersey Uniform Billing Records from 2006-2012. These data are compiled by the state from information that all general medical and surgical hospitals are required to submit about every individual encounter with a patient. These records have the hospital, the child's diagnosis, and the type of insurance coverage. ${ }^{5}$ We include all records where there is an emergency room

\footnotetext{
${ }^{4}$ We deleted a small number of children who died before their first birthday. Most of these children died within the first month of life and so would not have been "eligible" to be diagnosed with asthma. We also deleted a small number of children with birth weights less than 518 grams (the .25 th percentile of the sample distribution) or above 4820 grams (the 99.75 th percentile) as these have a high probability of being data entry errors.

${ }^{5}$ The Uniform Billing data includes up to three detailed payer code variables for each visit (primary, secondary, and tertiary), which reflect the specific type of insurance used. Each payer code is classified into seven payer types: Medicare, Medicaid, Commercial, Blue Cross, HMO, Self-Pay, and Other. We recategorize this information into two groups based on the primary payer: The first category, "public", consists of Medicaid (Medicaid and Medicaid HMOs), NJ FamilyCare (New Jersey's Children's Health Insurance
} 
revenue code on the billing record; some of these visits would have resulted in admission to the hospital but in most cases the patient is seen in the ER and returns home. Note that whether or not the visit resulted in admission, it appears in our data.

We matched birth records and ER visits by sex of child, date of birth, and first and last name of the child. ${ }^{6}$ This process created a unique patient identifier, so that we can follow each child over time and across hospitals in the Uniform Billing Records. Similarly, we matched siblings in the birth records using characteristics of the mother including her first and last name, birth date, and social security number. The matching algorithm does a good job catching slight misspellings without lumping together names that look different in a manual inspection of these data. More details on the matching process and the quality of the algorithm can be found in the Data Appendix.

Along with the sibling match, the ability to observe all visits to all hospitals is a particular strength of these data. It is possible to measure the total number of emergency room visits even if the child was treated at multiple hospitals. We use this aspect of these data to keep track of the total number of times a child was treated in the emergency room for asthma.

A key contribution of our paper is to examine non-African-American children living in black zip codes, and to compare their outcomes to African-American children also living in black zip codes. We define black zip codes so that half of the children living in black zip codes are African-American (pooled across all black zip codes). That is, black zip codes are defined as those with the highest fraction of black children in the sample. This definition yields a sample in which the non-black zip codes have at least $73 \%$ non-black children.

By this metric, 94 out of 676 zip codes are classified as black zip codes. The rationale

Program (CHIP)), and the indigent. (Indigent children make up just $0.5 \%$ of the public insurance category. We include them in the public category because their expenses are likely to eventually be paid by public insurance even if they are not publicly insured at the time of admission.) The "private" category consists of Blue Cross, non Medicaid/NJ FamilyCare HMOs, and other commercial insurers. Those with military insurance (CHAMPUS) are classified as "private" since their coverage is similar to that of the privately insured. One strength of the data is that we can identify both Medicaid fee for service and Medicaid HMO patients as publicly insured patients. Further details about the coding are in the Data Appendix.

${ }^{6}$ The Levenshtein edit distance is used to match names, because of problems with typographical errors and misspellings (stata command strgroup -- http://fmwww.bc.edu/repec/bocode/s/strgroup.html). 
behind this choice is to have the same power to estimate birth weight-asthma profiles for African-American and for other children in black zip codes. The zip codes we define as "black" are also those in which the majority of black children live: $63.4 \%$ of black children in our sample live in one of these zip codes, compared to only $15.9 \%$ of other children.

The cutoff percent black that achieves a split such that half of the children living in black zip codes are African-American is $27 \%$ black. Our results are not sensitive to using alternative cutoffs to define the black zip codes; Appendix Tables A1 through A4 show that our results are robust to using cut offs $5 \%$ higher or lower than our preferred specification. Using a cut off requiring at least $22 \%$ of children in a zip code to be black, 109 zip codes are designated as black zip codes; using a cut off requiring least $32 \%$ of children in a zip code to be black yields 75 black zip codes. An alternative and reasonable categorization would be to define the cutoff such that half of the black children in our sample are in black zip codes, and half of the black children are in other zip codes. In practice, this results in a fairly similar threshold, and would mean setting the cutoff at essentially the same level as in Tables A.3 and A.4. On the other hand, defining black zip codes as those with at least 50 percent black seems just as arbitrary as our preferred specification, and would result in a very small sample of non-black children residing in black zip codes. ${ }^{7}$

Figure 1 shows that most black zip codes follow a diagonal line from the Northeast to the Southwest of the state, along the path of the New Jersey Turnpike, while a few others are located along the Garden State Parkway. They are also clustered around older, poorer cities, such as Camden, Trenton, and Newark.

Table 1 provides an overview of child and mother characteristics from the birth certificate data, broken out by race and whether the child's mother lived in a black zip code or not at the time of the birth. The first two rows indicate that there is a large gap in asthma rates by race, but that there is also a large gap by type of zip code. African-American children

\footnotetext{
${ }^{7}$ Defining black zip codes as those with at least 50 percent black would result in 55 black zip codes, with 28,258 black children and 10,601 non-black children. The sample size of non-black children in this specification is just 20 percent of that in our preferred specification.
} 
in black zip codes are 4.38 percentage points more likely to have been ever diagnosed with asthma than African-American children in other zip codes. Among non-black children, this gap is almost the same at 4.83 percentage points. One can see that the same patterns emerge for birth weight, with African-American children being more likely to be low birth weight, but also large gaps in birth weight across types of zip codes within racial groups.

However, one can also see from Table 2 that within race groups the children in black zip codes are negatively selected. Their mothers are more likely to have smoked during pregnancy, are more likely to be high school dropouts, are less likely to be married, more likely to have public rather than private insurance, and are more likely to be having a higher order birth. The patterns of selection are somewhat different across racial groups. For example, non-black mothers in black zip codes are more likely to be high school drop outs than any other group, whereas African-American mothers in black zip codes are the least likely to be married and the most likely to be less than 20 years old. These patterns make it unclear whether we should attribute high asthma rates among children in black zip codes to residence in the zip code or to the characteristics of people who happen to live in those zip codes. The models discussed below will attempt to untangle these relationships.

Because we focus on differences in asthma by residential location, we also collect information about zip codes from the 2010 Census including: total population in 2010, population per square mile (population density), median age, average household size, the percentage of people age 25 and older with less than a high school degree and with a bachelor's degree, the percentage of people aged sixteen and over in the labor force, the percentage of households with an income less than $\$ 20,000$ per year, the percentage of households with incomes greater than $\$ 200,000$ per year, the percentage of households below the poverty line, the median age of the structures, the percent of housing that is owner occupied, the percentage of housing that is vacant, the median value of owner occupied housing, and the average commute. Together these variables capture many aspects of socioeconomic status and disadvantage that are often associated with black neighborhoods. 
In addition to neighborhood characteristics from the Census, we have created additional measures that attempt to measure pollution exposure. For outdoor air pollution, these measures are the average distance from zip code centroids to the 25 largest point source emitters of PM 2.5 in New Jersey (as defined by the EPA, from 2011); and the fraction of the population of a zip code living in census blocks with centroids within $800 \mathrm{~m}$ or $400 \mathrm{~m}$ of a limited access highway (to capture pollution from vehicle emissions). For indoor air pollution, we look at the fraction of mothers in a zip code who reported smoking during pregnancy, as well as two measures proxying for the quality of the housing stock: the percent of housing left vacant, and the percent built before 1960 .

Table 2 shows the population weighted means of these variables for all zip codes, black zip codes, and other zip codes. Overall, 94 zip codes are classified as black, while 582 zip codes are not. Table 2 indicates that black zip codes tend to be more densely populated and to have more young children. Consistent with Table 1, residents of black zip codes tend to be less educated, and are more than twice as likely to be in poverty. Houses are an average of seven years older in black zip codes, and people are much more likely to be renters. Those in black zip codes are also exposed to more pollution, both indoor and outdoor, as measured by our proxies. Black zip codes are on average half the distance to top polluting facilities compared to other zip codes, and a larger fraction of the population of black zip codes live close to limited access highways. In addition, a slightly higher fraction of mothers in black zip codes report smoking during pregnancy, and the housing stock in these areas is both older and more likely to be vacant---both of with are associated with indoor air pollution from mold and rodent and insect infestations. Once again, this table suggests that residents of black zips suffer multiple disadvantages, which could well be reflected in lower birth weights and a higher propensity to have asthma among their children. 


\section{Methods}

We explore the relationship between asthma, race, birth weight, and location, using Ordinary Least Squares (OLS) models. We first estimate models of the form:

$$
\text { Asthma }_{i z}=a_{0}+a_{1} \text { BirthWeight }_{i}+a_{2} \text { Black }_{i}+a_{3} \text { BirthWeight }_{i} * \text { Black }_{i}+q_{i}+e_{i z},
$$

where $A_{\text {sthma }}$ is either a zero-one indicator equal to one if child $i$ in zipcode $z$ was ever diagnosed with asthma in the course of a hospital visit, or a count of the number of times the child was diagnosed with asthma during a hospital visit; BirthWeight ${ }_{i}$ is a vector of indicators for birth weight categories including 500 to 999 grams, 1000 to 1499 grams ... 4500 to 4999 grams (the reference category is normal birth weight of 3000 to 3499 grams); Black $_{i}$ indicates that the child's mother is African-American; and BirthWeight $t_{i}$ Black $_{i}$ is the intersection of the two. We also include $q_{i}$ : fixed effects for each child's age in quarters as of the end of our sample (this is equivalent to including a separate control for each year and quarter of birth combination in the data). Controlling for age allows for the fact that older children have a longer window in which they could have been diagnosed with asthma. This regression describes the asthma-birth weight profile, and how it differs by race.

We next add controls for child, mother, and location specific characteristics as well as fixed effects for each hospital (since asthma in young children can be difficult to diagnose and might be reported differently at different hospitals):

$$
\begin{aligned}
\text { Asthma }_{i z}= & a_{0}+a_{1} \text { BirthWeight }_{i}+a_{2} \text { Black }_{i}+a_{3} \text { BirthWeight }_{i} * \text { Black }_{i} \\
& +a_{4} \text { Xind }_{i}+a_{5} \text { Xzip }_{z}+a_{6} \text { Hospital }_{i}+e_{i z}
\end{aligned}
$$

where the vector $X_{i n d}$ captures individual mother and child characteristics including all 
of the explanatory variables listed in Table 1, as well as each child's age in quarters as of the end of our sample. The vector $X z i p_{z}$ captures the zip code level characteristics listed in Table 2, and Hospital $_{i}$ is a vector of hospital fixed effects. ${ }^{8}$

Next we modify (2) by adding mother fixed effects, denoted $a_{m}$. This specification controls for all fixed characteristics of the mother including race, and asks whether within families, lower birth weight children are more likely to have asthma:

$$
\begin{aligned}
\text { Asthma }_{i z}= & a_{m}+a_{1} \text { BirthWeight }_{i}+a_{2} \text { BirthWeight }_{i} * \text { Black }_{i}+a_{4} \text { Xind }_{i}^{\prime} \\
& +a_{5} \text { Xzip } \text { Bi }_{z}^{\prime}+a_{6} \text { Hospital }_{i}+e_{i z}
\end{aligned}
$$

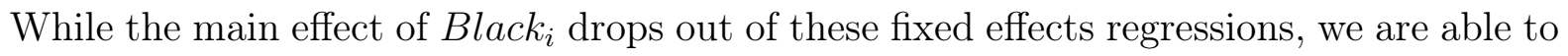
include interactions of BirthWeight ${ }_{i} * B$ Back $_{i}$, and the estimated coefficients are indicative of the extent to which low birth weight has a larger effect on African-American than on other children. The vectors $X i n d_{i}^{\prime}+X z i p_{z}^{\prime}$ now include only time varying characteristics of mothers, and zip codes.

We expect that our measure of whether a child ever had asthma should be fairly clean: most children with asthma will have ended up with at least one trip to the ER, since having a child who can't breathe is a medical emergency that is terrifying to parents. The number of trips to the hospital for asthma, however, is related both to the severity of the child's asthma, but also other factors such as the availability of outpatient care for the child and how faithful the family is about medication adherence. These are factors that may be partially controlled by including mother-specific fixed effects.

Finally, in order to explore the effect of location, we estimate models (2) and (3) separately for black and other zip codes. These regressions address whether different propensities to have asthma conditional on birth weight are found across areas, and whether there are racial

\footnotetext{
${ }^{8}$ If a child is seen at more than one hospital, we use the hospital the child visited the most frequently in Hospital . $_{\text {. }}$
} 
differences in birth-weight specific asthma rates within areas. When we estimate maternal fixed effects models separately by type of zip code, the identifying variation comes from mothers who have more than one child with different birthweights (we count women as living in a black zip code if we ever observe them giving birth in a black zip code). ${ }^{9}$ While mother fixed effects models are not a panacea, we include them for comparison with models that control for a rich set of observable controls, and for comparison with previous work using siblings. We show below that the estimated relationships between race, asthma, and birth weight are quite similar with and without maternal fixed effects, but differ across types of zip codes, lending further support to the conclusion that characteristics of the zip code itself are important rather than characteristics of the people who happen to live in them being determinative. ${ }^{10}$

\section{Results}

Table 3 shows estimates of the effects of race and birth weight on the probability of ever having been diagnosed with asthma during a hospital visit in columns 1 to 3 . Estimates of the number of times the child has been diagnosed with asthma during a hospital visit appear in columns 4 to $6 .^{11}$ The first column does not include any additional controls beyond birth weight and length of time a child spent in the sample, so it provides a simple description of the relationship between asthma prevalence and birth weight. Column 1 shows that relative to

\footnotetext{
${ }^{9}$ An alternative strategy would be to use mothers who move between different zip code types. However, in practice very few mothers move between Black and other zip codes between children (just 3,683 mothers have a child in both zip code types). Appendix Table A.11 restricts the sample to those that do move between zip code types and tries to estimate the effect of black zip codes via movers. Unfortunately there are very few remaining observations, and very few of the coefficients are statistically significant.

${ }^{10}$ An alternative specification would involve examining models with a complete set of interactions between an indicator for black race, LBW, and living in a black zip code. Such a specification is shown in Appendix Table A.10. In these models, the indicator for $\mathrm{LBW}^{*}$ black zip is statistically significant, but the triple difference indicator LBW*black zip*black is not. This finding is consistent with the results discussed below as it suggests that it is living in a black zip code rather than being black that is associated with higher asthma rates among LBW children.

${ }^{11}$ While our main specification uses OLS for both of our outcomes---whether a child has ever been diagnosed with asthma and the number of times a child has been diagnosed with asthma at an ER---Table A.5 shows that our results are robust to using zero-inflated negative binomial models when looking at the number of visits. This technique is designed to deal with count data with many zeroes.
} 
normal birth weight babies (3000 to 3499 grams) the lightest non African-American infants are 15.4 percentage points more likely to be subsequently diagnosed with asthma. This increased probability of asthma falls monotonically with birth weight and becomes negligible around the cutoff for low birth weight (2500 grams). The indicator for Black shows that African-American babies of all birth weights are more likely to be diagnosed with asthma than other children.

However, the interactions between the birth weight categories and whether the baby is African-American show that while there is a higher probability of asthma among black infants, the racial gap in asthma prevalence is much greater for the lightest infants. An African-American baby of 500 to 999 grams is 33.1 percentage points more likely to ever be diagnosed with asthma than a non African-American baby with a birth weight of 3000 to 3499 grams. This gap falls to 9.1 percentage points for African-American babies 3000 to 3499 grams and to 5.6 percentage points for the heaviest African-American babies. The F-test shown at the bottom of the table is from a test of the hypothesis that the interactions of the four lowest birth weight categories with the indicator for black race are jointly significantly different than zero, and confirms that black LBW babies are more likely to suffer from asthma than white babies with LBW $(\mathrm{F}=13.95)$.

Comparing columns (1) and (2) of Table 3 suggests that adding a rich set of individual and area level controls, as well as hospital fixed effects, has little impact on the estimated asthma-birth weight profiles. ${ }^{12}$ It does however, reduce the "main effect" of black by about $50 \%$, showing that much of the level effect attributed to race can in fact be explained by other observable characteristics of families and neighborhoods (though of course $50 \%$ remains unexplained in this specification).

We thought it important a priori to include hospital fixed effects, as African-American children may systematically use hospitals with different practices or protocols related to reporting or diagnosing asthma. Moreover, since people tend to use the nearest hospital in an

\footnotetext{
${ }^{12}$ Table A.8 reports the coefficients on the included zip code level controls, which are suppressed in Table 3 .
} 
emergency, adding hospital fixed effects is similar to adding fixed effects for the geographical catchment area of each hospital. In practice, however, adding both hospital fixed effects and zip code level characteristics from the census have little to no impact on the magnitude or precision of the coefficients (see Tables A.6 and A.7). ${ }^{13}$

Column (3) of Table 3 shows that adding a fixed effect for each mother leaves the estimated asthma-birthweight profile largely intact. Hence, even comparing siblings born to the same mother, lower birth weight is strongly associated with a higher probability of asthma, and this effect is significantly larger for black mothers.

Columns (4) through (6) of Table 3 show similar qualitative patterns for the number of times a child is diagnosed with asthma during a hospital visit. Once again, the main effect of $B l a c k_{i}$ is halved when observable controls are added to the model, and the elevated effect of low birth weight among African-Americans persists even when controls for mother fixed effects are added to the model. ${ }^{14}$

In Table 4, we pursue the analysis of the effects of neighborhoods by dividing the sample into Black zips and other zip codes. Note that children are assigned to zip codes on the basis of their location at the time of the birth. One advantage of this procedure is that the location is chosen before information about the child's health is revealed. Thus, these estimates should not suffer from endogeneity associated with family's moving because of a child's respiratory problems.

A comparison of columns (1) and (2) and of columns (3) and (4) in Table 4 shows that in Black zip codes the effects of low birth weight are much larger, about twice as large, as in other zip codes for both African-Americans and others. In Black zip codes, even non African-American babies of 500 to 999 grams are 22.6 percentage points more likely to ever end up at the hospital ER with asthma than non African-American babies of normal birth weight (3000 to 3499 grams). An African-American baby of 500 to 999 grams would be 26.4

\footnotetext{
${ }^{13}$ Table A.7 shows that some racial gap in the the birth weight-asthma profile remains when zip code fixed effects are included, but this result is not inconsistent with the main results because there is a racial gap in the group of "other zip codes."

${ }^{14}$ Table A.9 shows that none of the results are sensitive to removing "other race" and Hispanic mothers.
} 
percentage points more likely to be diagnosed with asthma than white babies of normal birth weight but, as discussed further below, the two estimates are not statistically significantly different from each other for low birth weight babies.

Remarkably, in Black zip codes the profile of asthma and low birth weight is the same for all low birth weight children in these zip codes. In contrast, in other zip codes, AfricanAmerican children of low birth weight still face additional increases in the probability of having asthma beyond the level effect of Black ${ }_{i}$. In other zip codes, an African-American baby of 500 to 999 grams would be 26.4 percentage points more likely to ever have asthma than a non African-American baby of 3000 to 3499 grams, while for a non African American baby of 500 to 999 grams the equivalent figure would be 13.1 percentage points. One reason a difference might persist between black and non-black children in these other zip codes is that the average black child in this group is less comparable to the average non-black child. We address this issue in Table 5, which controls for time-invariant characteristics of the mother.

Table 5 shows estimates for black zip codes and other zip codes from models including mother fixed effects. In these models, the relationship between low birth weight and asthma is readily apparent, but remarkably, once we separate black zip codes and other zip codes, that relationship is exactly the same for white and black children in both types of zip codes. That is, unlike the mother fixed effects models shown in Table 3, when we stratify by black vs. non-black zip codes there is no statistically significant interaction between the birth weight categories and the indicator Black . The overall relationship between low birth weight and asthma is much the same as in Table 4, with the effects of low birth weight being twice as large for all children in black zip codes compared to other zip codes. These results strongly suggest that there are characteristics of black zip codes that contribute to higher asthma rates among all children living in those zip codes. ${ }^{15}$ Moreover, controlling for residential location in addition to the detailed controls and mother fixed effects completely explains the racial difference in asthma rates conditional on low birth weight.

\footnotetext{
${ }^{15} 83,187$ mothers only have children in black zip codes, 282,927 mothers only have children in other zip codes, and a small minority, 3,683 mothers, have at least one child in both black and other zip codes.
} 
These results are the most novel and striking of this paper. As discussed above, it has been quite difficult to explain the racial gap in asthma rates. Our results suggest that while some of the gap may be associated with characteristics of families, once we account for where people live, the gap among LBW children entirely disappears. This finding is important because it suggests that if we could identify the relevant characteristics of neighborhoods, it might be possible to address them, and that addressing these characteristics would benefit all children living in these neighborhoods.

The estimates presented in Tables 3, 4, and 5 and their confidence intervals are graphed as Figures 2, 3, and 4. These figures make it easier to see the overall effect of being AfricanAmerican at each birth weight (which includes the main effect Black the birth weight category, and the interaction between the two) and to compare it to the effect of low birth weight for other children. The standard error bands show visually where the estimates are significantly different and where their confidence bands overlap.

The left most panels of Figure 2 show estimates corresponding to columns (1) and (4) of Table 3. They show that the incidence of asthma, and the number of visits for asthma are always higher for African-American children, though the risks converge as birth weight rises. Moreover, among children who are not African-American, the risk of asthma for those at the high end of the LBW/low end of the normal birth weight range is not much higher than for normal birth weight children (the reference category is non-African-American children with a birth weight of 3000-3499 grams).

The middle panel of Figure 2 shows that the gap between African-Americans and others is considerably narrowed by the inclusion of basic controls for individual children and their mothers, neighborhoods, and hospitals. Remarkably, there is almost no change in the relationship between asthma risk and low birth weight among the non-African-American children. Hence, the narrower gap is entirely explained by the reduction in the extent to which asthma risk is attributed to race once controls are included in the models. In other words, much of the higher asthma risk among African-Americans can be explained by ob- 
servable characteristics of families, neighborhoods, and hospitals, though there is still a large unexplained residual gap at low birth weights.

The right hand panels of Figure 2 indicate that once all of the unobserved fixed characteristics of mothers are controlled for (which includes race), the profile of asthma risk and birth weight again narrows. However, the point estimates for African-Americans of low birth weight remain somewhat higher than those for other children, and these differences are statistically significant (see Table 3, columns 3 and 6).

Figure 3 shows estimates comparable to those in the middle panels of Figure 2 except that the sample is divided into black zip codes and other zip codes. Remarkably, as the left hand panels show, within black zip codes there is no statistically significant difference between African-American and other children in terms of the relationship between low birth weight and asthma risk. The convergence in rates within black zip codes comes about because while all children have higher asthma rates in black zip codes, non-African-American children have much higher asthma rates in black zip codes than in other zip codes. That is, black zip codes appear to be bad for all children (in terms of higher asthma rates), whereas in other zip codes there is still a gap between African-American and other children of low birth weight.

Any remaining differences between African-American and other children are eliminated in Figure 4, which shows estimates comparable to Figure 3, but with mother fixed effects. This Figure suggests that within the same families, low birth weight is only associated with higher asthma rates in black zip codes.

\section{Discussion}

Our study supports the growing consensus about the importance of place in the evolution of disadvantage as children grow. Our estimates suggest that black zip codes are less healthy places for all children, and that much of the gap in asthma rates between African-American and other children in New Jersey is attributable to their place of residence. Moreover, we 
have shown that all low birth weight children, regardless of race, are at higher risk of asthma if they live in these neighborhoods. This finding of course begs the question of what it is about these neighborhoods that contributes so strongly to triggering asthma in vulnerable low birth weight children?

Table 6 reports correlations between a wide range of zip code level characteristics: general neighborhood characteristics, adult respiratory disease burden, and indoor and outdoor air pollution proxies. As can be seen in Table 6, besides living in areas with higher outdoor air pollution (measured by distances to top emitting facilities and limited access highways), children in black zip codes also live in places where indoor air pollution is likely to be a serious issue. Especially if children in the worst neighborhoods spend a lot of time indoors, mold, dust, smoke, and fecal matter from insect and rodent infestations may play an outsized role in triggering asthma. Unfortunately there is very little systematic measurement of indoor air pollution levels in the US, and the best we can do is proxy for indoor air pollution with measures of the age and upkeep of the housing stock, and smoking rates.

Table 6 also shows that adults living in black zip codes have a high respiratory disease burden. Acute respiratory disease and allergic rhinitis (hay fever) are both known asthma triggers, and have been shown to be independently associated with indoor and outdoor air pollution. Adult COPD prevalence is both a measure of how much of a population smokes--itself an important type of indoor air pollution---and is another disease which is exacerbated by air pollution.

Finally, Table 6 shows that all our proxies for environmental asthma triggers are highly correlated with general neighborhood characteristics, such as the fraction of the population living below the poverty line, and the fraction of single mothers. Given the extensive literature on residential segregation, these strong correlations are not surprising.

Appendix Table A.12 shows that dividing our sample by poor vs. non-poor zip codes produces similar results to splitting by black vs. non-black zip codes. In Appendix Table A.12 high poverty zip codes are defined analogously to black zip codes, such that there 
are approximately the same number of black and non-black children in poor zip codes (the poverty rate that accomplishes this division is 16 percent). Nevertheless, splitting the sample by fraction black does a slightly better job of eliminating the racial differences in the birth weight-asthma gradient than splitting the sample by poverty rates.

Despite the fact that areas where black children tend to live are clearly poorer neighborhoods, asthma needs a physical trigger; poverty per se does not cause asthma. We think that higher levels of pollution in black zip codes could be an important trigger, but given the available data it is difficult to investigate this hypothesis. As discussed earlier, black zip codes tend to line up along the main highways in New Jersey, and Figure 5 shows that many of the top emitters of PM 2.5 are also located in or close to black zip codes. Figures A1 and A2 show that if we divide air monitoring stations into those that are within two miles of a black zip code and those that are more than two miles from a black zip code, monitoring stations located closer to black zip codes have higher air pollution levels. ${ }^{16}$ Unfortunately, there are far fewer monitors than zip codes, and thus we do not have good coverage of air pollution measures across the state (see Figures A3 and A4 for maps of monitor locations). Figure A5 shows major highways in New Jersey. The concentration of these highways in black zip codes is evident, but since we do not have consistent traffic count data, the best measure we can construct of exposure to pollution from traffic is distance from one of these roadways. When added to our main regression specifications, though, the resulting noisy measures explain little of the variation in asthma rates. ${ }^{17}$ However, we suspect that this result reflects the imperfections in the available measures. Finally, we suspect that indoor air pollution is an important asthma trigger, but we were not able to find any direct and geographically comprehensive measures of these sources.

While we focus on explaining the racial gap in asthma rates conditional on low birth

\footnotetext{
${ }^{16}$ Currie (2011) and Currie et al. (2016) suggest that living within a mile of plants emitting hazardous chemicals has detectable effects on infant health. Currie and Walker (2011) show that living within $2 \mathrm{~km}$ of a highway toll plaza also has negative effects on infant health.

${ }^{17}$ Including these noisy pollution measures has no effect on the magnitude or precision of reported coefficients. Results available upon request.
} 
weight, there is a growing literature pointing to pollution as one of the explanations for higher rates of low birth weight among African-American children (Currie, 2011; Aizer and Currie, 2015). African-American mothers are more likely to be exposed to many forms of pollution during pregnancy compared to other mothers, including pollution from traffic, emissions from manufacturing and power plants, and Superfund hazardous waste sites; they are also more likely to be exposed to hazardous water pollutants (Currie et al., 2013). Thus, pollution may explain both higher rates of low birth weight, and a higher propensity to develop asthma conditional on birth weight among African-Americans.

\section{Conclusions}

In this paper, we have focused on the racial gap in asthma rates, conditional on birth weight, and shown that the gap can be largely explained by observable characteristics of households plus their residential locations. Our results suggest that the racial gap in asthma rates arises for three reasons: Because African-American children are more likely to be low birth weight, because they are more likely to come from families with other characteristics that are associated with poorer health (such as maternal smoking and poverty), and because of where they live. It is striking that within black zip codes, all children have much higher asthma rates than in other zip codes, and that within these zip codes there is no statistically significant difference in asthma rates between the races conditional on low birth weight. Clearly, understanding what aspects of neighborhoods contribute most to these disparities is key to reducing the racial gap in asthma, and potentially in other health conditions.

\section{References}

Aizer, Anna and Janet Currie. "The Intergenerational Transmission of Inequality: Maternal Disadvantage and Health at Birth," Science, v344, May 23, 2014, p. 856.

Almond, Douglas, Janet Currie, and Valentina Duque. "Childhood Circumstances and Adult 
Outcomes: Act II," NBER Working Paper, \#XXXX, Nov. 2016.

Akinbami, Lara, Jeanne Moorman, Paul Garbe, Edward Sondik. "Status of Childhood Asthma in the United States, 1980-2007." Pediatrics, 129; S131, 2009.

Akinbami, Lara, Jeanne Moorman, Alan Simon, Kenneth Schoendorf. "Trends in Racial Disparities for Asthma Outcomes Among Children 0-17 Years, 2001-2010," Journal of Allergy and Clinical Immunology, v. 134 \#3, 547-533, Sept,2014.

American Lung Association, American Lung Association, Asthma and Children Fact Sheet, October 2012. http://www.lung.org/lung-disease/asthma/resources/facts-and-figures/asthmachildren-fact-sheet.html, accessed May 23, 2014.

Boustan, Leah. "Racial Residential Segregation in American Cities," Oxford Handbook of Economics and Planning, Nancy Brooks, Kieran Danaghy, Gerrit-Jan Knaap (eds.) (Oxford: Oxford University Press), 2011, 318-339.

Boustan, Leah and Robert Margo. "Racial Difference in Health in Long-Run Perspective: A Brief Introduction," NBER Working paper \#20765, Dec. 2014.

Case, Anne, Darren Lubotsky, and Christina Paxson. "Economic Status and Health in Childhood: The Origins of the Gradient," American Economic Review, v. 92 \#5, 2002: 1308-1334.

Chetty, Raj, Michael Stepner, Sarah Abraham, Shelby Lin, Benjamin Scuderi, Nicholas Turner, Augustin Bergeron, David Cutler. "The Association Between Income and Life Expectancy in the United States, 2001-2014," JAMA, 315 \#16, 2016a, 1750-1766.

Chetty, Raj, Nathaniel Hendren, and Lawrence F. Katz. "The Effects of Exposure to Better Neighborhoods on Children: New Evidence from the Moving to Opportunity Experiment," American Economic Review, 106(4), April 2016b, 855-902.

Condliffe, Simon and Charles R. Link. 2008. "The Relationship between Economic Status and Child Health: Evidence from the United States," American Economic Review, v. 98 \#4, Sept. 2008: 1605-1618.

Currie, Janet, Joshua Graff-Zivin, Katherine Meckel, Matthew Neidell, and Wolfram Schlenker. "Something in the Water: Contaminated Drinking Water and Infant Health," Canadian Journal of Economics, V46 \#3, August, 2013, 791-810.

Currie, Janet. "Inequality at Birth: Some Causes and Consequences," American Economic Review, May 2011, 101 \#3, 1-22.

Currie, Janet, Lucas Davis, Michael Greenstone, and Reed Walker. "Environmental Health Risks and Housing Values: Evidence from 1,600 Toxic Plant Openings and Closings." American Economic Review, 2015, 105(2): 678-709. 
Currie, Janet and Hannes Schwandt. "Mortality Inequality: The Good News from a CountyLevel Approach," Journal of Economic Perspectives, Spring 2016.

Currie, Janet and Mark Stabile. "Socioeconomic Status and Child Health: Why is the Relationship Stronger for Older Children?" American Economic Review, v 93 \#5, 2003: 1813-1823.

Currie, Janet and Reed Walker. "Traffic Congestion and Infant Health: Evidence from E-ZPass," American Economic Journal: Applied Economics, American Economic Association, vol. 3(1), Jan. 2011: pages 65-90.

Curtis, Lori, MartinDooley and Shelley Phipps. "Child Well-Being and Neighbourhood Quality: Evidence from the Candian National Longitudinal Survey of Children and Youth," Social Science and Medicine, v 58 \#10: 1917-1927.

Fortson, Jane and Lisa Sanbonmatsu. "Child Health and Neighborhood Conditions: Results from a Randomized Housing Voucher Experiment, " Journal of Human Resources, v 45 \#4, Fall 2010: 840-864.

Isen, Adam, Maya Rossin-Slater, W. Reed Walker. "Every Breath You Take Every Dollar You'll Make," Journal of Political Economy, v. 125 \#3, 2017: 848-901.

Jacob, Brian, Jens Ludwig, and Douglas Miller. "The Effects of Housing and Neighborhood Conditions on Child Mortality," Journal of Health Economics, 32, 2013: 195-206.

Kawachi, I and Lisa Berkman. "Neighbourhoods and Health" (Oxford University Press Inc: New York), 2003.

Kling, Jeffrey, Jeffrey Liebman and Lawrence Katz. "Experimental Analysis of Neighborhood Effects," Econometrica v 75 \#1, 2007: 83-119.

Mayo Clinic. "Childhood Asthma", March 2016. Accessed July 18, 2017. http://www.mayoclinic.org/diseas conditions/childhood-asthma/symptoms-causes/dxc-20193101?p=1

McDaniel, Marcia, Christina Paxson, and Jane Waldfogel. "Racial Disparities in Childhood Asthma in the United States: Evidence from the National Health Interview Survey, 1997 to 2003," Pediatrics, 2006.

Merkin, Sharon Stein, Ricardo Basurto-Davila, Arun Karlamangla, Chloe Bird, Nicole Lurie, Jose Escarce, and Teresa Seeman. "Neighborhoods and Cumulative Biological Risk Profiles by Race/Ethnicity in a National Sample of U.S. Adults: NHANES III," Annals of Epidemiology, v19 \#3, 2009: 194-201.

Nepomnyaschy, Lena and Nancy Reichman. "Low Birthweight and Asthma Among Young 
Urban Children," American Journal of Public Health, 2006.

Newacheck, Paul and Neil Halfon. "Prevalence, Impact, and Trends in Childhood Disability Due to Asthma," Archives of Pediatric and Adolescent Medicine, 154 \#3, 2000, 287-293.

Oreopoulos, Philip, Mark Stabile, Randy Walld, and Leslie L. Roos. 2008."Short-,Medium, and Long-Term Consequences of Poor Infant Health: An AnalysisUsing Siblings and Twins."J. Human Resources 43 (1): 88-138.

Ortqvist, Anne K., Cecilia Lundholm, Eva Carlstrom, Paul Lichtenstein, Sven Cnattingius, and Catarina Almqvist. "Familial Factors do Not Confound the Association Between Birth Weight and Childhood Asthma," Pediatrics, v. 124 \#4: e737-43, Oct., 2009.

Pickett, Kate and Michelle Pearl. "Multilevel Analyses of Neighbourhood Socioeconomic Context and Health Outcomes: A Critical Review," Journal of Epidemiology and Community Health, v 55 \#2, 2001: 111-122.

Villamor, Eduardo, Iliadou, Anastasia, and Cnattingius, Sven. "Is the Association Between Low Birth Weight and Asthma Independent of Genetic and Shared Environmental Factors?" American Journal of Epidemiology, v 169 \#11, 1337-1343, 2009.

WebMD. "Asthma in Children: Symptoms and Risk Factors", June 2016. Accessed July 18, 2017. http://www.webmd.com/asthma/children\#1 


\section{$9 \quad$ Figures}

\section{Figure 1: Map of Black Zip Codes}

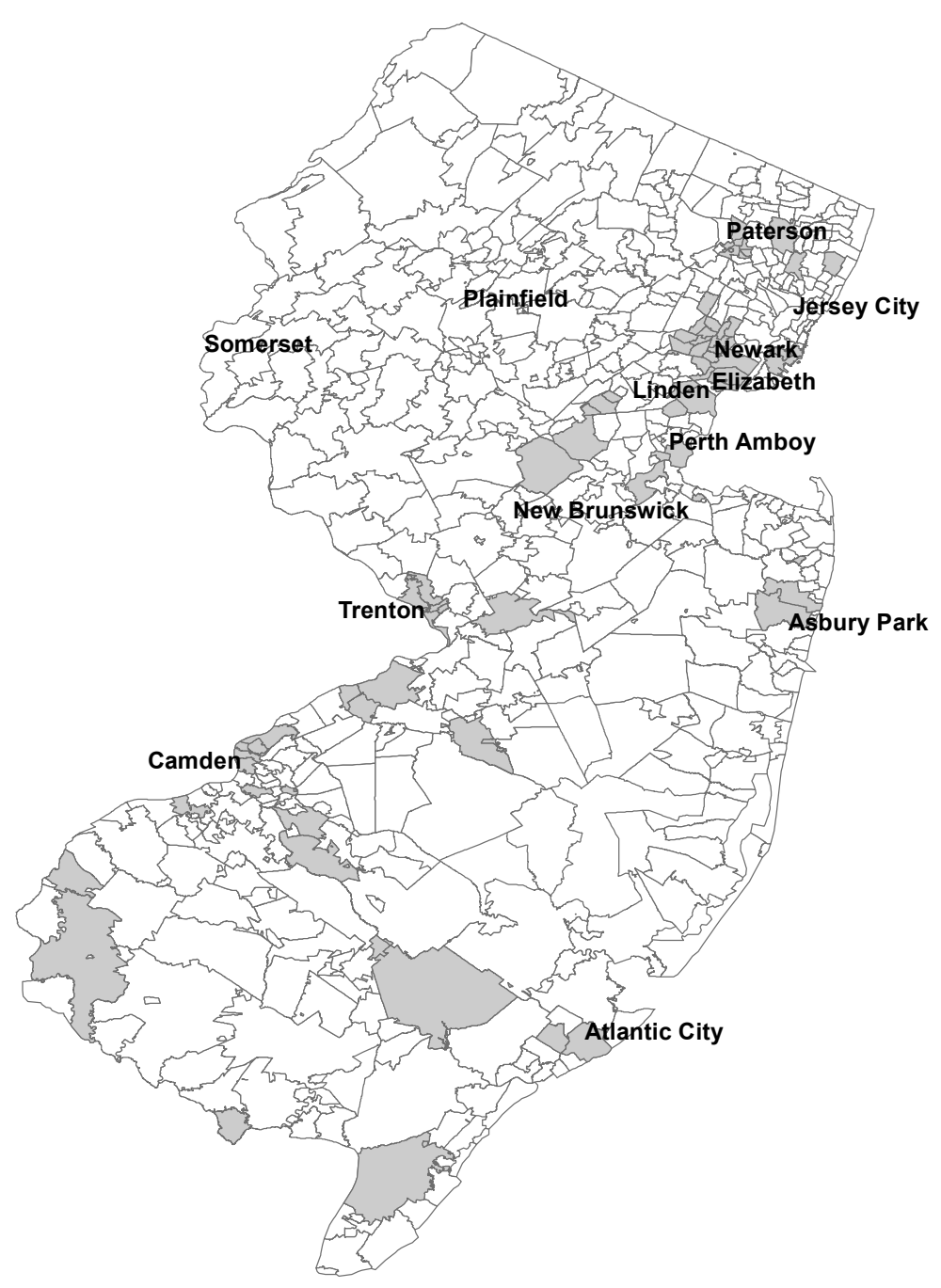

Notes: Grey denotes black zip codes, white denotes other zip codes. Black zip codes are zip codes with the highest fraction of black children, up until the point where there are approximately the same number of black children and non-black children in the black zip codes. The resulting threshold is that a zip code is defined as a Black zip code if the share of black children is at least 27 percent. The remaining zip codes are defined as other zip codes. As US Postal Service zip codes do not represent contiguous geographic boundaries, we map zip codes to census zip code tabulation areas for the purpose of this figure. 

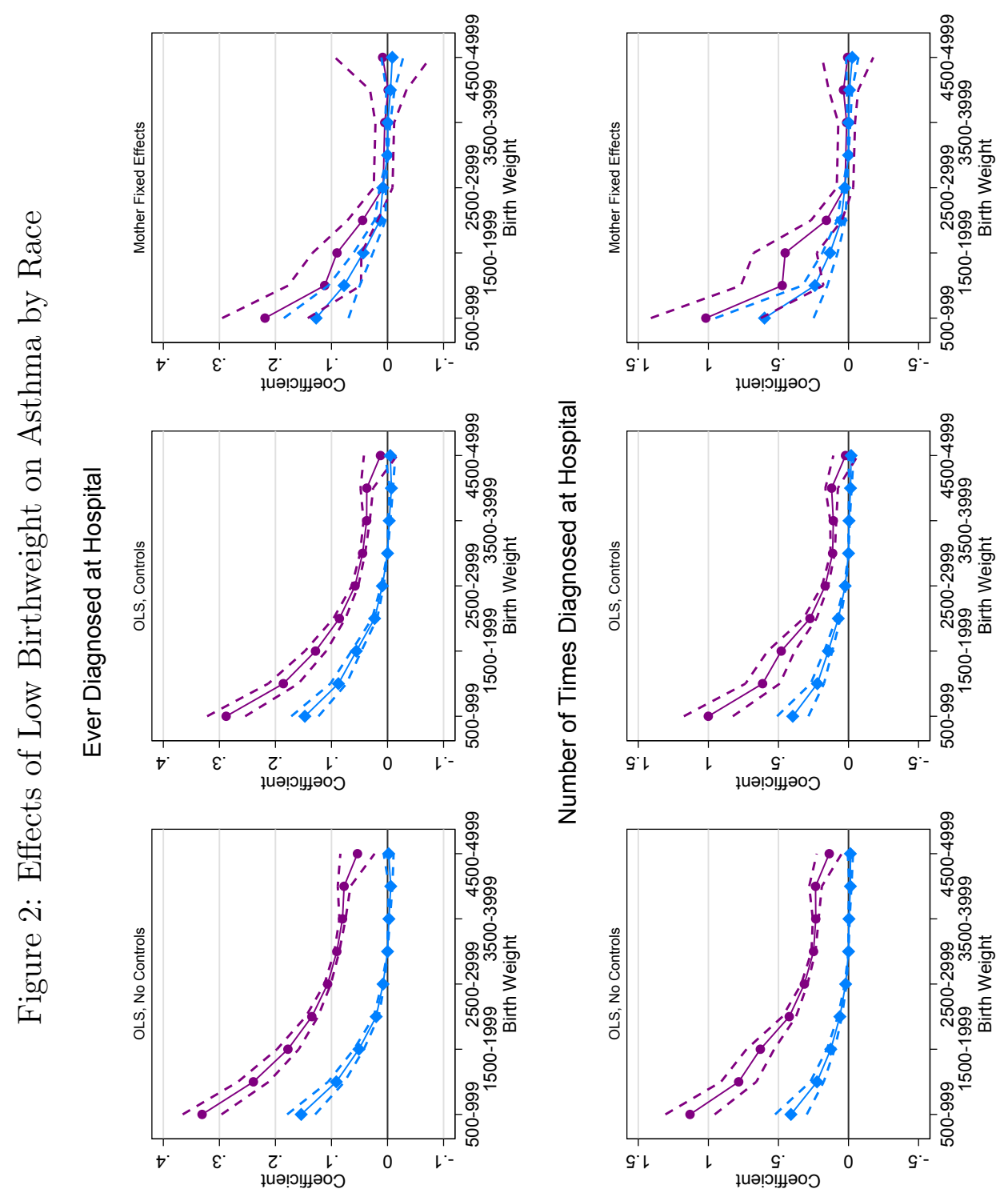

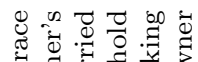

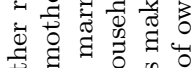

응

요의

溥

政安

160

i.

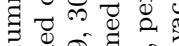

영 궁

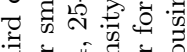

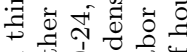

ธำ

ช

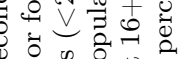

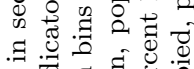

政

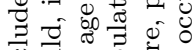

:

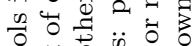

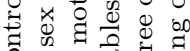

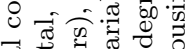

ฮี

$\therefore$ o $0 \overrightarrow{0}$

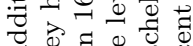

य

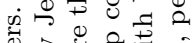

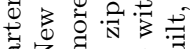

西 乙a

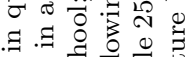

웡

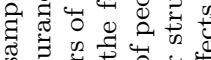

क

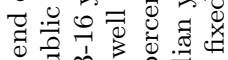

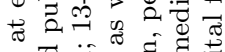

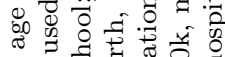

n

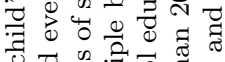

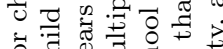

क

氜

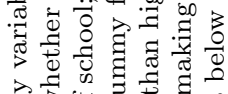

ठ

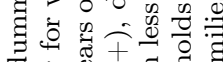

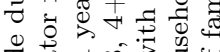

芑葋

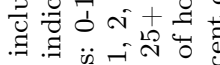

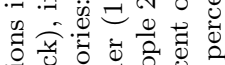

\%

ข.

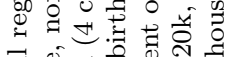

《.

is

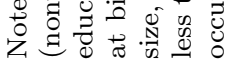




\section{Figure 3: Black Zip Codes Versus Other Zip Codes (OLS)}
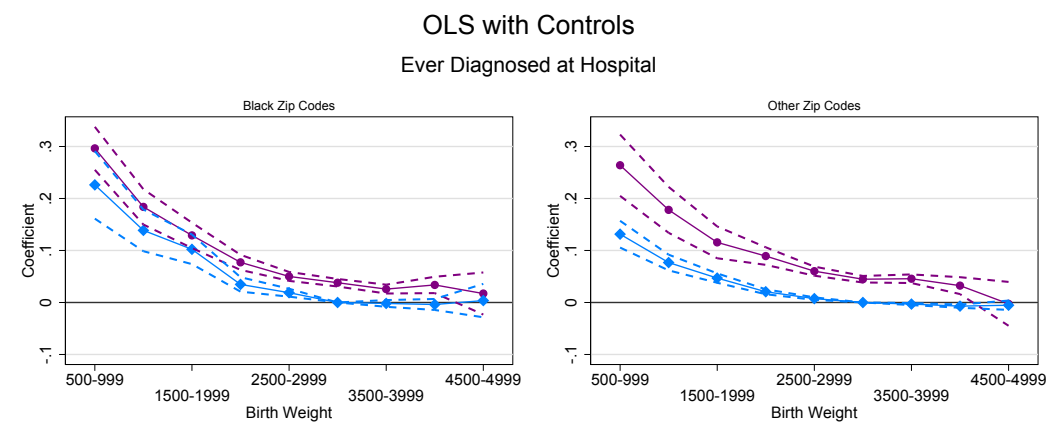

Number of Times Diagnosed at Hospital
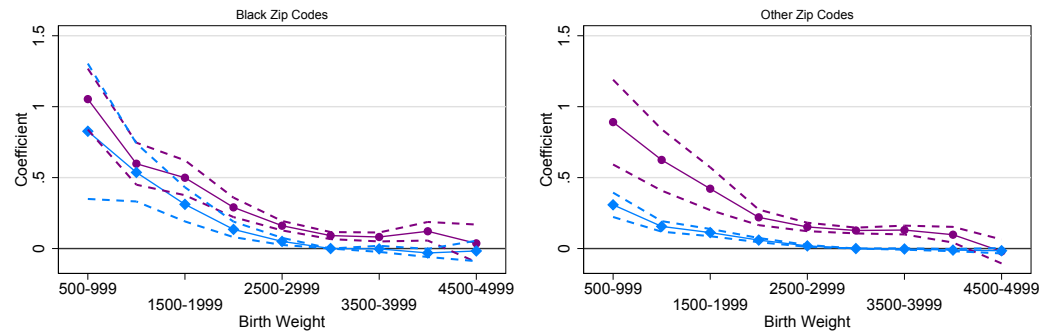

Black Mothers

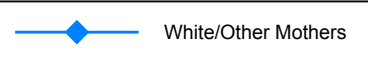

Notes: Additional controls included: dummy variables for child's age at end of sample in quarters, indicator for other race (nonwhite, nonblack), indicator for whether the child ever used public insurance in a New Jersey hospital, sex of child, indicator for mother smoked during pregnancy, mother's education (4 categories: 0-11 years of school; 12 years of school; 13-16 years of school; more than 16 years), mother's age in bins (<20, 20-24, 25-29, 30-34, 35+), mother married at birth, birth order (1, $2,3,4+$ ), dummy for multiple birth, as well as the following zip code level variables: population, population density, median age, average household size, percent of people $25+$ with less than high school education, percent of people $25+$ with bachelor's degree or more, percent $16+$ in labor force, percent of households making less than 20k, percent of households making more than 200k, median year structure built, percent of housing owner occupied, percent of housing vacant, median value of owner occupied housing, percent of families below poverty, and hospital fixed effects. Black zip codes are zip codes with the highest fraction of black children, up until the point where there are approximately the same number of black children and non-black children in the black zip codes. The remaining zip codes are defined as other zip codes. 
Figure 4: Black Zip Codes Versus Other Zip Codes (Mother Fixed Effects)

Mother Fixed Effects

Ever Diagnosed at Hospital
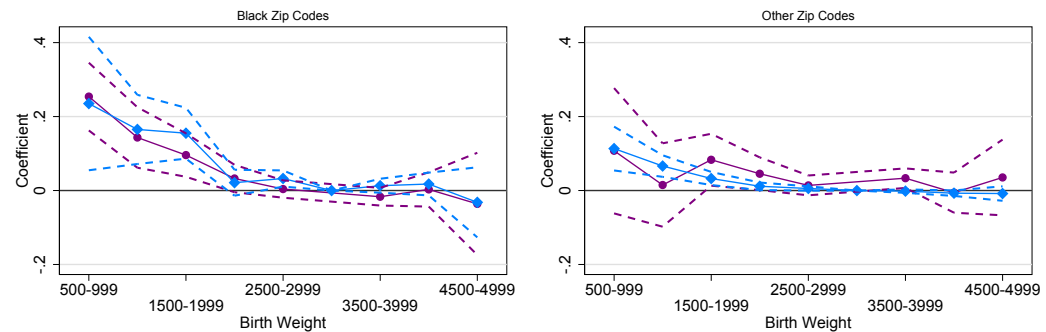

Number of Times Diagnosed at Hospital
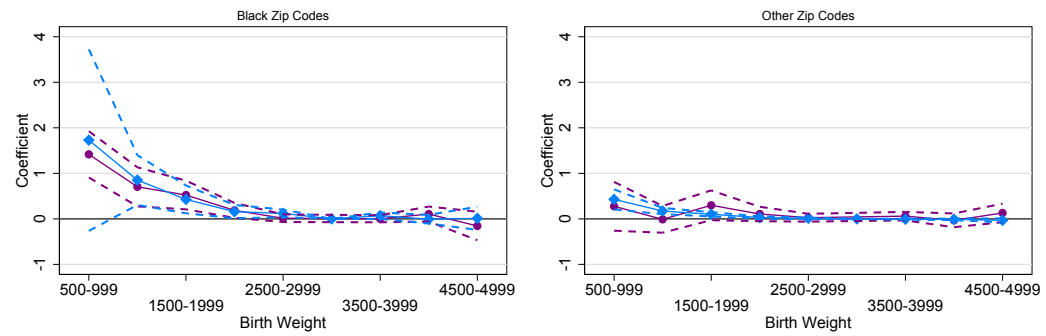

Black Mothers

White/Other Mothers

Notes: Additional controls included: dummy variables for child's age at end of sample in quarters, indicator for other race (nonwhite, nonblack), indicator for whether the child ever used public insurance in a New Jersey hospital, sex of child, indicator for mother smoked during pregnancy, mother's education (4 categories: 0-11 years of school; 12 years of school; 13-16 years of school; more than 16 years), mother's age in bins (<20, 20-24, 25-29, 30-34, 35+), mother married at birth, birth order (1, $2,3,4+$ ), dummy for multiple birth, as well as the following zip code level variables: population, population density, median age, average household size, percent of people $25+$ with less than high school education, percent of people $25+$ with bachelor's degree or more, percent $16+$ in labor force, percent of households making less than 20k, percent of households making more than $200 \mathrm{k}$, median year structure built, percent of housing owner occupied, percent of housing vacant, median value of owner occupied housing, percent of families below poverty, and hospital fixed effects. Black zip codes are zip codes with the highest fraction of black children, up until the point where there are approximately the same number of black children and non-black children in the black zip codes. The remaining zip codes are defined as other zip codes. 


\section{Figure 5: Top 25 Point Source Emitters: PM 2.5}

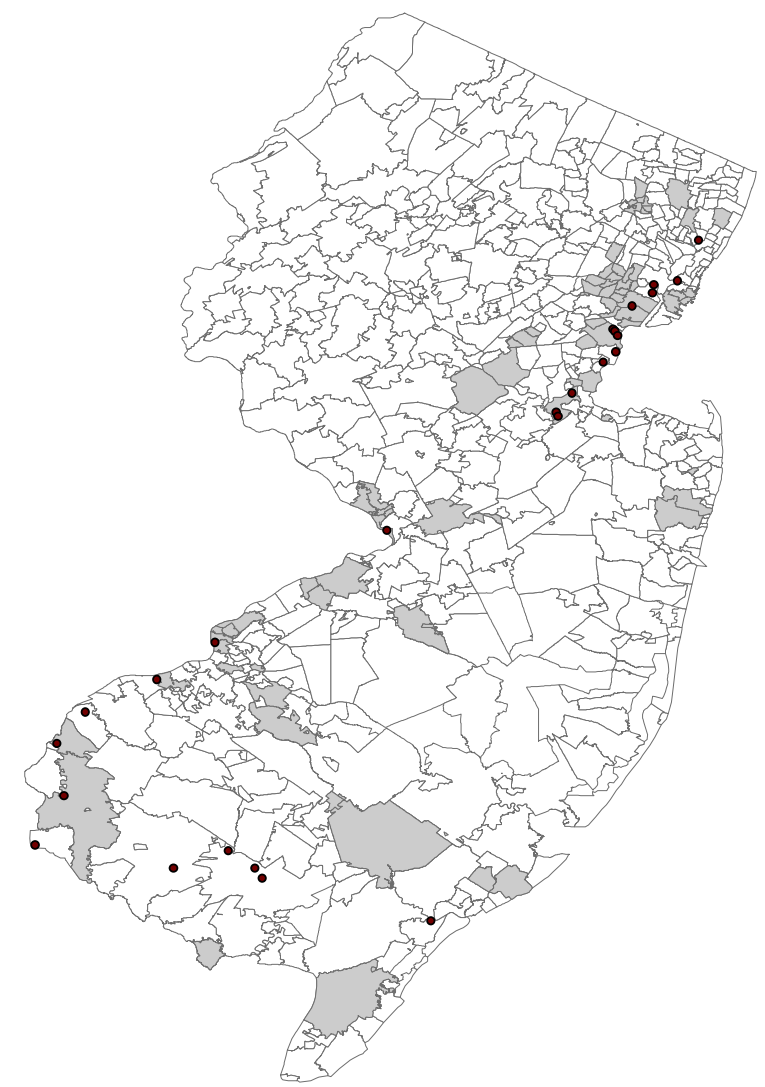

Notes: Grey denotes black zip codes, white denotes other zip codes. Black zip codes are zip codes with the highest fraction of black children, up until the point where there are approximately the same number of black children and non-black children in the black zip codes. The remaining zip codes are defined as other zip codes. As US Postal Service zip codes do not represent contiguous geographic boundaries, we map zip codes to census zip code tabulation areas for the purpose of this figure. The facilities displayed are the top 25 biggest emitters of PM 2.5 in New Jersey, in 2011 (EPA). 


\section{Tables}

Table 1: Individual-Level Summary Statistics

\begin{tabular}{|c|c|c|c|c|}
\hline & $\begin{array}{r}\mathrm{Bl} \\
\text { Black Zips }\end{array}$ & $\begin{array}{l}\text { ack } \\
\text { Other Zips }\end{array}$ & $\begin{array}{r}\text { White } \\
\text { Black Zips }\end{array}$ & $\begin{array}{l}\text { Other } \\
\text { Other Zips }\end{array}$ \\
\hline Asthma: pct. ever diagnosed & 18.07 & 13.69 & 10.89 & 6.06 \\
\hline \multicolumn{5}{|l|}{ Explanatory variables } \\
\hline Pct. $500-999 \mathrm{~g}$ & 1.12 & 0.88 & 0.39 & 0.29 \\
\hline Pct. $1000-1499 \mathrm{~g}$ & 1.48 & 1.29 & 0.87 & 0.66 \\
\hline Pct. $1500-1999 \mathrm{~g}$ & 2.70 & 2.29 & 1.58 & 1.50 \\
\hline Pct. 2000-2499g & 7.03 & 6.63 & 5.02 & 4.64 \\
\hline Pct. $2500-2999 g$ & 23.68 & 21.80 & 18.57 & 16.86 \\
\hline Pct. $3000-3499 g$ & 38.08 & 38.91 & 39.78 & 38.80 \\
\hline Pct. $3500-3999 \mathrm{~g}$ & 20.83 & 22.69 & 26.30 & 28.70 \\
\hline Pct. $4000-4499 \mathrm{~g}$ & 4.53 & 4.91 & 6.80 & 7.72 \\
\hline Pct. $4500-4999 \mathrm{~g}$ & 0.55 & 0.61 & 0.69 & 0.83 \\
\hline Pct. other race & 0.00 & 0.00 & 14.71 & 14.51 \\
\hline Pct. smoked & 8.89 & 7.11 & 6.12 & 5.32 \\
\hline Mother's educ.: pct. 0-11 yrs & 17.37 & 11.58 & 25.48 & 9.50 \\
\hline Mother's educ.: pct. 12 yrs & 42.74 & 33.25 & 32.41 & 21.75 \\
\hline Mother's educ.: pct. $13-16$ yrs & 33.40 & 42.58 & 31.37 & 46.63 \\
\hline Mother's educ.: pct. $17+$ yrs & 5.79 & 11.89 & 10.13 & 21.64 \\
\hline Pct. boy & 50.73 & 50.97 & 50.81 & 51.12 \\
\hline Pct. married & 29.31 & 46.63 & 52.39 & 79.27 \\
\hline Mother's age: pct. less than 20 & 11.94 & 7.78 & 6.89 & 2.52 \\
\hline Mother's age: pct. $20-24$ & 27.17 & 21.97 & 21.97 & 11.84 \\
\hline Mother's age: pct. $25-29$ & 25.74 & 25.10 & 27.57 & 23.83 \\
\hline Mother's age: pct. $30-24$ & 20.05 & 24.13 & 25.56 & 34.41 \\
\hline Mother's age: pct. $35+$ & 15.10 & 21.02 & 18.01 & 27.39 \\
\hline Birth order: 1 & 38.45 & 38.23 & 39.03 & 39.02 \\
\hline Birth order: 2 & 28.95 & 31.43 & 32.82 & 34.11 \\
\hline Birth order: 3 & 17.77 & 17.53 & 17.18 & 16.74 \\
\hline Birth order: $4+$ & 14.83 & 12.82 & 10.98 & 10.12 \\
\hline Pct. multiple birth & 3.96 & 4.43 & 3.28 & 4.88 \\
\hline Child age in quarters at end & 17.36 & 17.44 & 17.43 & 17.65 \\
\hline Pct. ever publicly insured & 65.67 & 55.39 & 59.42 & 35.81 \\
\hline \multicolumn{5}{|l|}{ Sample size } \\
\hline Black Children & 49,122 & 28,418 & 0 & 0 \\
\hline White/Other Children & 0 & 0 & 50,844 & 319,652 \\
\hline
\end{tabular}

Notes: Facilities are the top 25 largest emitters of PM 2.5 in 2011, according to the EPA. Other race category is $40.8 \%$ Asian Indian, $23.1 \%$ other and unspecified race, $11.5 \%$ Filipino, $9.8 \%$ Chinese, and $8.4 \%$ Korean (the remaining categories are Vietnamese, American Indian, Japanese, and Pacific Islander). Black zip codes are zip codes with the highest fraction of black children, up until the point where there are approximately the same number of black children and non-black children in the black zip codes. The remaining zip codes are defined as other zip codes. 


\section{Table 2: Zip Code-Level Summary Statistics}

Black Zip Codes Other Zip Codes All Zip Codes

Explanatory variables

Total population 2010

Pop. per square mile

34,095

28,726

29,862

Median age

9,797

4,757

5,823

Avg. household size

35.44

39.88

38.94

2.77

2.72

2.73

Pct. less than high school $(25+)$

19.37

10.96

12.74

Pct. bachelors or more $(25+)$

24.17

38.19

35.22

Pct. in labor force $(16+)$

66.04

66.95

66.76

Pct. households less than 20k

22.19

12.07

14.21

Pct. households greater than $200 \mathrm{k}$

4.11

10.20

8.91

Median year structure built

1960

1967

1965

Pct. owner occupied

46.87

70.15

65.23

Pct. vacant units

11.57

7.62

8.45

Median value owner occuptied

270,317

353,676

336,035

Pct. families below poverty

15.43

6.30

8.23

Average commute

28.71

30.35

30.01

Pollution proxies

Distance to top polluting facility

8.32

16.33

14.70

Pct. within $400 \mathrm{~m}$ of highway

0.51

0.44

0.45

Pct. within $800 \mathrm{~m}$ of highway

0.73

0.61

0.63

Pct. smoked during pregnancy

0.07

0.06

0.06

Pct. housing stock built $<1960$

0.54

0.41

0.44

Zips

94

582

676

Notes: From 2010 Census/American Community Survey. Zip code characteristics weighted by population. Black zip codes are zip codes with the highest fraction of black children, up until the point where there are approximately the same number of black children and non-black children in the black zip codes. The remaining zip codes are defined as other zip codes. Pct. smoked is the percent of mothers in the zip code who reported smoking during pregnancy; pct. vacant is the percent of the housing stock reported vacant; built $<1960$ is the fraction of the housing stock built before 1960; facility distance is the distance to nearest high polluting facility (top 25 facilities by PM 2.5 emissions in 2011 , as reported by the EPA); within $400 \mathrm{~m}$ and $800 \mathrm{~m}$ are the fraction of a zip code whose census block is within that distance of a limited access highway. 
Table 3: Asthma and Low Birthweight

\begin{tabular}{|c|c|c|c|c|c|c|}
\hline & \multicolumn{3}{|c|}{ Ever Diagnosed with Asthma } & \multicolumn{3}{|c|}{ No. Times Diagnosed with Asthma } \\
\hline $500-999$ & $\begin{array}{c}0.154^{* * *} \\
(0.013)\end{array}$ & $\begin{array}{c}0.148^{* * *} \\
(0.012)\end{array}$ & $\begin{array}{c}0.127^{* * *} * \\
(0.029)\end{array}$ & $\begin{array}{c}0.411^{* * *} \\
(0.058)\end{array}$ & $\begin{array}{c}0.398 * * * \\
(0.057)\end{array}$ & $\begin{array}{c}0.599 * * * \\
(0.179)\end{array}$ \\
\hline 1000-1499 & $\begin{array}{c}0.091^{* * *} * \\
(0.007)\end{array}$ & $\begin{array}{c}0.088^{* * * *} \\
(0.007)\end{array}$ & $\begin{array}{c}0.078^{* * * *} \\
(0.014)\end{array}$ & $\begin{array}{c}0.225^{* * *} \\
(0.025)\end{array}$ & $\begin{array}{c}0.223^{* * * *} \\
(0.024)\end{array}$ & $\begin{array}{c}0.240^{* * *} * \\
(0.045)\end{array}$ \\
\hline 1500-1999 & $\begin{array}{c}0.051^{* * *} * \\
(0.004)\end{array}$ & $\begin{array}{c}0.056^{* * *} * \\
(0.004)\end{array}$ & $\begin{array}{c}0.043^{* * *} * \\
(0.009)\end{array}$ & $\begin{array}{c}0.127^{* * *} \\
(0.014)\end{array}$ & $\begin{array}{c}0.145^{* * *} * \\
(0.015)\end{array}$ & $\begin{array}{c}0.133^{* * *} * \\
(0.028)\end{array}$ \\
\hline 2000-2499 & $\begin{array}{c}0.020^{* * *} \\
(0.002)\end{array}$ & $\begin{array}{c}0.023^{* * * *} \\
(0.002)\end{array}$ & $\begin{array}{c}0.014^{* * * *} \\
(0.005)\end{array}$ & $\begin{array}{c}0.062^{* * *} \\
(0.007)\end{array}$ & $\begin{array}{c}(0.015) \\
0.073^{* * *} \\
(0.008)\end{array}$ & $0.052^{* * *}$ \\
\hline 2500-2999 & $\begin{array}{c}0.008^{* * * *} \\
(0.001)\end{array}$ & $\begin{array}{c}0.009^{* * *} * \\
(0.001)\end{array}$ & $\begin{array}{c}0.009 * * * \\
(0.003)\end{array}$ & $\begin{array}{c}0.021 * * * \\
(0.003)\end{array}$ & $\begin{array}{c}0.024^{* * *} * \\
(0.003)\end{array}$ & $\begin{array}{c}0.027^{* * *} * \\
(0.008)\end{array}$ \\
\hline 3500-3999 & $\begin{array}{c}-0.002^{* *} \\
(0.001)\end{array}$ & $\begin{array}{c}-0.003^{* * *} \\
(0.001)\end{array}$ & $\begin{array}{l}-0.000 \\
(0.002)\end{array}$ & $\begin{array}{l}-0.003 \\
(0.003)\end{array}$ & $\begin{array}{l}-0.004 \\
(0.003)\end{array}$ & $\begin{array}{c}-0.001 \\
(0.006)\end{array}$ \\
\hline $4000-4499$ & $\begin{array}{c}-0.006^{* * *} \\
(0.002)\end{array}$ & $\begin{array}{c}-0.007^{* * *} * \\
(0.002)\end{array}$ & $\begin{array}{l}-0.005 \\
(0.004)\end{array}$ & $\begin{array}{c}-0.013^{* * *} \\
(0.004)\end{array}$ & $\begin{array}{c}-0.014^{* * *} * \\
(0.004)\end{array}$ & $\begin{array}{l}-0.007 \\
(0.009)\end{array}$ \\
\hline $4500-4999$ & $\begin{array}{l}-0.002 \\
(0.004)\end{array}$ & $\begin{array}{l}-0.005 \\
(0.004)\end{array}$ & $\begin{array}{l}-0.008 \\
(0.010)\end{array}$ & $\begin{array}{l}-0.013 \\
(0.010)\end{array}$ & $\begin{array}{c}-0.018^{*} \\
(0.010)\end{array}$ & $\begin{array}{l}-0.026 \\
(0.023)\end{array}$ \\
\hline Black & $\begin{array}{c}0.091^{* * *} * \\
(0.002)\end{array}$ & $\begin{array}{c}0.045^{* * * *} \\
(0.002)\end{array}$ & $\begin{array}{c}0.000 \\
(.)\end{array}$ & $\begin{array}{c}0.250^{* * *} * \\
(0.007)\end{array}$ & $\begin{array}{c}0.113^{* * *} * \\
(0.008)\end{array}$ & $\begin{array}{c}0.000 \\
(.)\end{array}$ \\
\hline $500-999 *$ black & $\begin{array}{c}0.086^{* * *} * \\
(0.022)\end{array}$ & $\begin{array}{c}0.096^{* * * *} \\
(0.021)\end{array}$ & $\begin{array}{l}0.091^{*} \\
(0.049)\end{array}$ & $\begin{array}{c}0.471^{* * *} * \\
(0.107)\end{array}$ & $\begin{array}{c}0.489^{* * *} * \\
(0.106)\end{array}$ & $\begin{array}{c}0.419 \\
(0.267)\end{array}$ \\
\hline 1000-1499* black & $\begin{array}{c}0.057^{* * *} * \\
(0.016)\end{array}$ & $\begin{array}{c}0.054^{* * *} \\
(0.016)\end{array}$ & $\begin{array}{c}0.035 \\
(0.036)\end{array}$ & $\begin{array}{c}0.309 * * * \\
(0.069)\end{array}$ & $\begin{array}{c}0.277^{* * *} * \\
(0.067)\end{array}$ & $\begin{array}{c}0.234 \\
(0.157)\end{array}$ \\
\hline $1500-1999 *$ black & $\begin{array}{c}0.036^{* * *} * \\
(0.011)\end{array}$ & $\begin{array}{c}0.028^{* * *} \\
(0.011)\end{array}$ & $\begin{array}{c}0.047^{* *} \\
(0.024)\end{array}$ & $\begin{array}{c}0.253^{* * *} \\
(0.053)\end{array}$ & $\begin{array}{c}0.222^{* * *} \\
(0.052)\end{array}$ & $\begin{array}{c}0.319^{* * *} \\
(0.119)\end{array}$ \\
\hline $2000-2499 *$ black & $\begin{array}{c}0.024^{* * *} \\
(0.006)\end{array}$ & $\begin{array}{c}0.018^{* * *} * \\
(0.006)\end{array}$ & $\begin{array}{c}0.031^{* *} \\
(0.015)\end{array}$ & $\begin{array}{c}0.112^{* * *} \\
(0.027)\end{array}$ & $\begin{array}{c}0.089^{* * *} * \\
(0.026)\end{array}$ & $\begin{array}{l}0.106^{*} \\
(0.058)\end{array}$ \\
\hline $2500-2999 *$ black & $\begin{array}{c}0.008^{* *} \\
(0.004)\end{array}$ & $\begin{array}{c}0.004 \\
(0.004)\end{array}$ & $\begin{array}{l}-0.001 \\
(0.009)\end{array}$ & $\begin{array}{c}0.045^{* * *} \\
(0.014)\end{array}$ & $\begin{array}{c}0.029^{* *} \\
(0.013)\end{array}$ & $\begin{array}{c}-0.002 \\
(0.031)\end{array}$ \\
\hline $3500-3999 *$ black & $\begin{array}{c}-0.008^{* *} \\
(0.004)\end{array}$ & $\begin{array}{l}-0.004 \\
(0.003)\end{array}$ & $\begin{array}{c}0.005 \\
(0.009)\end{array}$ & $\begin{array}{l}-0.013 \\
(0.013)\end{array}$ & $\begin{array}{l}-0.001 \\
(0.013)\end{array}$ & $\begin{array}{c}0.015 \\
(0.031)\end{array}$ \\
\hline $4000-4499 *$ black & $\begin{array}{l}-0.007 \\
(0.006)\end{array}$ & $\begin{array}{l}-0.001 \\
(0.006)\end{array}$ & $\begin{array}{c}0.004 \\
(0.017)\end{array}$ & $\begin{array}{c}-0.001 \\
(0.024)\end{array}$ & $\begin{array}{c}0.021 \\
(0.024)\end{array}$ & $\begin{array}{c}0.043 \\
(0.054)\end{array}$ \\
\hline $4500-4999 *$ black & $\begin{array}{c}-0.035^{* *} \\
(0.016)\end{array}$ & $\begin{array}{c}-0.027^{*} \\
(0.016)\end{array}$ & $\begin{array}{c}0.017 \\
(0.045)\end{array}$ & $\begin{array}{c}-0.099^{* *} \\
(0.047)\end{array}$ & $\begin{array}{l}-0.074 \\
(0.046)\end{array}$ & $\begin{array}{c}0.033 \\
(0.096)\end{array}$ \\
\hline Individual/census vars & - & $\mathrm{x}$ & $\mathrm{x}$ & - & $\mathrm{x}$ & $\mathrm{x}$ \\
\hline Hospital fixed effects & - & $\mathrm{x}$ & $\mathrm{x}$ & - & $\mathrm{x}$ & $\mathrm{x}$ \\
\hline Mother fixed effects & - & - & $\mathrm{x}$ & - & - & $\mathrm{x}$ \\
\hline $\begin{array}{l}\text { Observations } \\
\text { R-squared } \\
\text { Mean dep. var. } \\
\text { Clusters } \\
\text { F-statistic } \\
\text { P-value }\end{array}$ & $\begin{array}{c}448,036 \\
0.026 \\
0.084 \\
369,797 \\
11.958 \\
0.000\end{array}$ & $\begin{array}{c}46,152 \\
0.066 \\
0.084 \\
368,295 \\
10.714 \\
0.000\end{array}$ & $\begin{array}{c}446,152 \\
0.023 \\
0.084 \\
368,295 \\
2.282 \\
0.058\end{array}$ & $\begin{array}{c}448,036 \\
0.024 \\
0.179 \\
369,797 \\
18.506 \\
0.000\end{array}$ & $\begin{array}{c}46,152 \\
0.056 \\
0.179 \\
368,295 \\
15.718 \\
0.000\end{array}$ & $\begin{array}{c}446,152 \\
0.022 \\
0.179 \\
368,295 \\
2.515 \\
0.039\end{array}$ \\
\hline
\end{tabular}

Notes: All regressions include dummy variables for child's age at end of sample in quarters. Other included controls: other race, mother smoked during pregnancy, mother's education (in years: 0-11, 12, 13-16, 16+), mother's age $(<20,20-24,25-$ 29, 30-34, 35+), mother married at birth, sex, birth order $(1,2,3,4+)$, multiple birth indicator, indicator for other race (non-white, non-black), and indicator for child ever used public insurance; zip code level variables: population, population density, median age, average household size, pct. with less than high school $(25+)$, pct. with bachelor's degree or more $(25+)$, pct. in labor force $(16+)$, pct. of households making $<20 \mathrm{k}$, pct. of households making $>200 \mathrm{k}$, median year structure built, pct. of housing owner occupied, pct. of housing vacant, median value of owner occupied housing, pct. of families below poverty. F-statistic/P-value from a test that the coefficients on the first 4 birthweight bins interacted with black are jointly equal to zero. Standard errors clustered at mother. The omitted categories are 3000-3499 and 3000-3499* black. 
Table 4: Asthma and Low Birth Weight: by Black Zip Codes

\begin{tabular}{|c|c|c|c|c|c|c|}
\hline & \multicolumn{3}{|c|}{ Ever Diagnosed with Asthma } & \multicolumn{3}{|c|}{$\begin{array}{l}\text { No. Times Diagnosed with Asthma } \\
\text { (3) }\end{array}$} \\
\hline 500-999 & $\begin{array}{c}0.226 * * * \\
(0.033)\end{array}$ & $\begin{array}{c}0.131^{* * *} \\
(0.013)\end{array}$ & 0.0077 & $\begin{array}{c}0.827^{* * * *} \\
(0.244)\end{array}$ & $\begin{array}{c}0.309 * * * \\
(0.044)\end{array}$ & 0.0361 \\
\hline 1000-1499 & $\begin{array}{c}0.139^{* * * *} \\
(0.020)\end{array}$ & $\begin{array}{c}0.077^{* * *} * \\
(0.008)\end{array}$ & 0.0046 & $\begin{array}{c}0.537^{* * *} \\
(0.104)\end{array}$ & $\begin{array}{c}0.156^{* * *} \\
(0.019)\end{array}$ & 0.0003 \\
\hline 1500-1999 & $\begin{array}{c}0.102^{* * * *} \\
(0.015)\end{array}$ & $\begin{array}{c}0.047^{* * * *} \\
(0.005)\end{array}$ & 0.0003 & $\begin{array}{c}0.312^{* * *} \\
(0.061)\end{array}$ & $\begin{array}{c}0.113^{* * *} * \\
(0.013)\end{array}$ & 0.0015 \\
\hline 2000-2499 & $\begin{array}{c}0.035^{* * *} \\
(0.007)\end{array}$ & $\begin{array}{c}0.021^{* * *} \\
(0.002)\end{array}$ & 0.0581 & $\begin{array}{c}0.135^{* * * *} \\
(0.028)\end{array}$ & $\begin{array}{c}0.060^{* * * *} \\
(0.008)\end{array}$ & 0.0089 \\
\hline 2500-2999 & $\begin{array}{c}0.019^{* * *} \\
(0.004)\end{array}$ & $\begin{array}{c}0.007^{* * *} \\
(0.001)\end{array}$ & 0.0051 & $\begin{array}{c}0.050^{* * *} \\
(0.013)\end{array}$ & $\begin{array}{c}0.019^{* * *} \\
(0.003)\end{array}$ & 0.0166 \\
\hline 3500-3999 & $\begin{array}{l}-0.002 \\
(0.003)\end{array}$ & $\begin{array}{c}-0.003^{* * *} \\
(0.001)\end{array}$ & 0.7199 & $\begin{array}{l}-0.002 \\
(0.011)\end{array}$ & $\begin{array}{l}-0.003 \\
(0.003)\end{array}$ & 0.9357 \\
\hline 4000-4499 & $\begin{array}{l}-0.004 \\
(0.005)\end{array}$ & $\begin{array}{c}-0.007^{* * *} \\
(0.002)\end{array}$ & 0.5698 & $\begin{array}{c}-0.031^{* *} \\
(0.015)\end{array}$ & $\begin{array}{l}-0.011^{* * *} \\
(0.004)\end{array}$ & 0.1845 \\
\hline $4500-4999$ & $\begin{array}{c}0.004 \\
(0.016)\end{array}$ & $\begin{array}{l}-0.005 \\
(0.005)\end{array}$ & 0.5984 & $\begin{array}{l}-0.017 \\
(0.037)\end{array}$ & $\begin{array}{l}-0.015 \\
(0.010)\end{array}$ & 0.9661 \\
\hline Black & $\begin{array}{c}0.038^{* * * *} \\
(0.004)\end{array}$ & $\begin{array}{c}0.045^{* * * *} \\
(0.003)\end{array}$ & 0.1670 & $\begin{array}{c}0.091 * * * \\
(0.013)\end{array}$ & $\begin{array}{c}0.127^{* * *} * \\
(0.010)\end{array}$ & 0.0284 \\
\hline 500-999* black & $\begin{array}{c}0.032 \\
(0.039)\end{array}$ & $\begin{array}{c}0.088^{* * *} \\
(0.033)\end{array}$ & 0.2772 & $\begin{array}{c}0.135 \\
(0.266)\end{array}$ & $\begin{array}{c}0.456^{* * *} \\
(0.159)\end{array}$ & 0.3005 \\
\hline 1000-1499* black & $\begin{array}{c}0.007 \\
(0.027)\end{array}$ & $\begin{array}{l}0.057^{* *} \\
(0.024)\end{array}$ & 0.1684 & $\begin{array}{l}-0.030 \\
(0.129)\end{array}$ & $\begin{array}{c}0.341^{* * *} \\
(0.112)\end{array}$ & 0.0294 \\
\hline 1500-1999* black & $\begin{array}{l}-0.011 \\
(0.019)\end{array}$ & $\begin{array}{c}0.024 \\
(0.016)\end{array}$ & 0.1623 & $\begin{array}{c}0.096 \\
(0.089)\end{array}$ & $\begin{array}{c}0.182^{* *} \\
(0.078)\end{array}$ & 0.4664 \\
\hline 2000-2499* black & $\begin{array}{c}0.004 \\
(0.010)\end{array}$ & $\begin{array}{c}0.024^{* *} \\
(0.009)\end{array}$ & 0.1568 & $\begin{array}{c}0.064 \\
(0.044)\end{array}$ & $\begin{array}{c}0.033 \\
(0.031)\end{array}$ & 0.5660 \\
\hline $2500-2999 *$ black & $\begin{array}{l}-0.007 \\
(0.006)\end{array}$ & $\begin{array}{c}0.008 \\
(0.005)\end{array}$ & 0.0664 & $\begin{array}{c}0.019 \\
(0.022)\end{array}$ & $\begin{array}{c}0.006 \\
(0.018)\end{array}$ & 0.6457 \\
\hline 3500-3999* black & $\begin{array}{l}-0.010^{*} \\
(0.005)\end{array}$ & $\begin{array}{c}0.004 \\
(0.005)\end{array}$ & 0.0573 & $\begin{array}{l}-0.008 \\
(0.020)\end{array}$ & $\begin{array}{c}0.006 \\
(0.019)\end{array}$ & 0.6068 \\
\hline 4000-4499* black & $\begin{array}{l}-0.000 \\
(0.010)\end{array}$ & $\begin{array}{l}-0.005 \\
(0.009)\end{array}$ & 0.7088 & $\begin{array}{l}0.061^{*} \\
(0.037)\end{array}$ & $\begin{array}{l}-0.019 \\
(0.030)\end{array}$ & 0.0914 \\
\hline 4500-4999* black & $\begin{array}{l}-0.024 \\
(0.026)\end{array}$ & $\begin{array}{l}-0.042^{*} \\
(0.022)\end{array}$ & 0.6091 & $\begin{array}{l}-0.038 \\
(0.077)\end{array}$ & $\begin{array}{l}-0.132^{* * *} \\
(0.045)\end{array}$ & 0.2897 \\
\hline Individual/census vars & $\mathrm{x}$ & $\mathrm{x}$ & & $\mathrm{x}$ & $\mathrm{x}$ & \\
\hline Hospital fixed effects & $\mathrm{x}$ & $\mathrm{x}$ & & $\mathrm{x}$ & $\mathrm{x}$ & \\
\hline $\begin{array}{l}\text { Observations } \\
\text { R-squared } \\
\text { Mean dep. var. } \\
\text { Clusters } \\
\text { F-statistic } \\
\text { P-value }\end{array}$ & $\begin{array}{c}99,647 \\
0.071 \\
0.144 \\
86,609 \\
0.330 \\
0.858\end{array}$ & $\begin{array}{c}346,505 \\
0.049 \\
0.067 \\
285,225 \\
4.852 \\
0.001\end{array}$ & & $\begin{array}{c}99,647 \\
0.057 \\
0.357 \\
86,609 \\
0.865 \\
0.484\end{array}$ & $\begin{array}{c}346,505 \\
0.042 \\
0.128 \\
285,225 \\
5.794 \\
0.000\end{array}$ & \\
\hline
\end{tabular}

Notes: Other included controls: other race, mother smoked during pregnancy, mother's education (in years: 0-11, 12, 13-16, $16+)$, mother's age $(<20,20-24,25-29,30-34,35+)$, mother married at birth, sex, birth order $(1,2,3,4+)$, multiple birth indicator, indicator for other race (non-white, non-black), indicator for child ever used public insurance, and dummy variables for child's age at end of sample in quarters; zip code level variables: population, population density, median age, average household size, pct. with less than high school $(25+)$, pct. with bachelor's degree or more $(25+)$, pct. in labor force $(16+)$, pct. of households making $<20 \mathrm{k}$, pct. of households making $>200 \mathrm{k}$, median year structure built, pct. of housing owner occupied, pct. of housing vacant, median value of owner occupied housing, pct. of families below poverty. F-statistic/P-value from a test that the coefficients on the first 4 birthweight bins interacted with black are jointly equal to zero. Standard errors clustered at mother. The omitted categories are 3000-3499 and 3000-3499* black. Reported P-values are for a Chow test that the coefficient is the same across black and other zip codes. 
Table 5: Asthma and Low Birth Weight: by Black Zip Codes, with Mother Fixed Effects

\begin{tabular}{|c|c|c|c|c|}
\hline & \multicolumn{2}{|c|}{$\begin{array}{l}\text { Ever Diagnosed with Asthma } \\
\begin{array}{l}(1) \\
\text { Black Zips }\end{array} \\
(2) \\
\text { Other Zips }\end{array}$} & \multicolumn{2}{|c|}{ No. Times Diagnosed with Asthma } \\
\hline $500-999$ & $\begin{array}{r}0.235 * * \\
(0.092)\end{array}$ & $0.114^{* * *}$ & $\begin{array}{l}1.730^{*} \\
(1.018)\end{array}$ & $0.429 * * *$ \\
\hline $1000-1499$ & $\begin{array}{c}0.165^{* * * *} \\
(0.048)\end{array}$ & $\begin{array}{c}0.066^{* * * *} \\
(0.015)\end{array}$ & $\begin{array}{c}0.852^{* * * *} \\
(0.279)\end{array}$ & $\begin{array}{c}0.172^{* * * *} \\
(0.034)\end{array}$ \\
\hline 1500-1999 & $\begin{array}{c}0.155^{* * *} \\
(0.035)\end{array}$ & $\begin{array}{c}0.033^{* * *} \\
(0.009)\end{array}$ & $\begin{array}{c}0.428^{* * *} \\
(0.156)\end{array}$ & $\begin{array}{c}0.101^{* * *} \\
(0.024)\end{array}$ \\
\hline $2000-2499$ & $\begin{array}{l}0.021 \\
(0.018)\end{array}$ & $\begin{array}{l}0.012^{* *} \\
(0.005)\end{array}$ & $\begin{array}{c}0.159^{* *} \\
(0.075)\end{array}$ & $\begin{array}{c}0.029^{* *} \\
(0.013)\end{array}$ \\
\hline $2500-2999$ & $\begin{array}{c}0.033^{* * * *} \\
(0.011)\end{array}$ & $\begin{array}{l}0.006^{*} \\
(0.003)\end{array}$ & $\begin{array}{c}0.121^{* * *} * \\
(0.043)\end{array}$ & $\begin{array}{l}0.013^{*} \\
(0.007)\end{array}$ \\
\hline $3500-3999$ & $\begin{array}{l}0.013 \\
(0.010)\end{array}$ & $\begin{array}{l}-0.002 \\
(0.002)\end{array}$ & $\begin{array}{l}0.071^{* *} \\
(0.035)\end{array}$ & $\begin{array}{l}-0.008 \\
(0.005)\end{array}$ \\
\hline $4000-4499$ & $\begin{array}{l}0.018 \\
(0.016)\end{array}$ & $\begin{array}{r}-0.007^{*} \\
(0.004)\end{array}$ & $\begin{array}{l}-0.007 \\
(0.049)\end{array}$ & $\begin{array}{l}-0.010 \\
(0.009)\end{array}$ \\
\hline $4500-4999$ & $\begin{array}{l}-0.032 \\
(0.048)\end{array}$ & $\begin{array}{l}-0.008 \\
(0.010)\end{array}$ & $\begin{array}{c}0.012 \\
(0.130)\end{array}$ & $\begin{array}{l}-0.032 \\
(0.022)\end{array}$ \\
\hline $500-999 *$ black & $\begin{array}{c}0.019 \\
(0.103)\end{array}$ & $\begin{array}{l}-0.006 \\
(0.092)\end{array}$ & $\begin{array}{l}-0.313 \\
(1.043)\end{array}$ & $\begin{array}{l}-0.152 \\
(0.295)\end{array}$ \\
\hline $1000-1499 *$ black & $\begin{array}{l}-0.022 \\
(0.063)\end{array}$ & $\begin{array}{l}-0.051 \\
(0.059)\end{array}$ & $\begin{array}{l}-0.148 \\
(0.352)\end{array}$ & $\begin{array}{l}-0.183 \\
(0.153)\end{array}$ \\
\hline $1500-1999 *$ black & $\begin{array}{l}-0.059 \\
(0.046)\end{array}$ & $\begin{array}{l}0.051 \\
(0.037)\end{array}$ & $\begin{array}{l}0.096 \\
(0.225)\end{array}$ & $\begin{array}{l}0.197 \\
(0.168)\end{array}$ \\
\hline $2000-2499 *$ black & $\begin{array}{c}0.011 \\
(0.026)\end{array}$ & $\begin{array}{l}0.034 \\
(0.023)\end{array}$ & $\begin{array}{l}0.028 \\
(0.111)\end{array}$ & $\begin{array}{l}0.078 \\
(0.082)\end{array}$ \\
\hline $2500-2999 *$ black & $\begin{array}{l}-0.029^{*} \\
(0.016)\end{array}$ & $\begin{array}{c}0.008 \\
(0.014)\end{array}$ & $\begin{array}{l}-0.107^{*} \\
(0.060)\end{array}$ & $\begin{array}{c}0.014 \\
(0.045)\end{array}$ \\
\hline 3500-3999* black & $\begin{array}{l}-0.030^{*} \\
(0.015)\end{array}$ & $\begin{array}{c}0.035^{* *} \\
(0.014)\end{array}$ & $\begin{array}{l}-0.068 \\
(0.053)\end{array}$ & $\begin{array}{l}0.068 \\
(0.048)\end{array}$ \\
\hline 4000-4499* black & $\begin{array}{l}-0.015 \\
(0.028)\end{array}$ & $\begin{array}{l}0.001 \\
(0.028)\end{array}$ & $\begin{array}{l}0.113 \\
(0.096)\end{array}$ & $\begin{array}{l}-0.022 \\
(0.077)\end{array}$ \\
\hline $4500-4999 *$ black & $\begin{array}{l}-0.004 \\
(0.085)\end{array}$ & $\begin{array}{c}0.044 \\
(0.053)\end{array}$ & $\begin{array}{l}-0.167 \\
(0.205)\end{array}$ & $\begin{array}{c}0.163 \\
(0.106)\end{array}$ \\
\hline Individual/census vars & $\mathrm{x}$ & $\mathrm{x}$ & $\mathrm{x}$ & $\mathrm{x}$ \\
\hline Hospital fixed effects & $\mathrm{x}$ & $\mathrm{x}$ & $\mathrm{x}$ & $\mathrm{x}$ \\
\hline Mother fixed effects & $\mathrm{x}$ & $\mathrm{x}$ & $\mathrm{x}$ & $\mathrm{x}$ \\
\hline $\begin{array}{l}\text { Observations } \\
\text { R-squared } \\
\text { Mean dep. var. } \\
\text { Clusters } \\
\text { F-statistic } \\
\text { P-value }\end{array}$ & $\begin{array}{c}99,647 \\
0.050 \\
0.084 \\
86,609 \\
0.619 \\
0.649\end{array}$ & $\begin{array}{c}346,505 \\
0.018 \\
0.084 \\
285,225 \\
1.245 \\
0.289\end{array}$ & $\begin{array}{c}99,647 \\
0.044 \\
0.179 \\
86,609 \\
0.147 \\
0.965\end{array}$ & $\begin{array}{c}346,505 \\
0.016 \\
0.179 \\
285,225 \\
1.258 \\
0.284\end{array}$ \\
\hline
\end{tabular}

Notes: Other included controls: other race, mother smoked during pregnancy, mother's education (in years: $0-11,12,13-16,16+)$, mother's age $(<20,20-24,25-29,30-34,35+)$, mother married at birth, sex, birth order $(1,2,3,4+)$, multiple birth indicator, indicator for other race (non-white, non-black), indicator for child ever used public insurance, and dummy variables for child's age at end of sample in quarters; zip code level variables: population, population density, median age, average household size, pct. with less than high school $(25+)$, pct. with bachelor's degree or more $(25+)$, pct. in labor force $(16+)$, pct. of households making $<20 \mathrm{k}$, pct. of households making $>200 \mathrm{k}$, median year structure built, pct. of housing owner occupied, pct. of housing vacant, median value of owner occupied housing, pct. of families below poverty. F-statistic/P-value from a test that the coefficients on the first 4 birthweight bins interacted with black are jointly equal to zero. Standard errors clustered at mother. The omitted categories are 3000-3499, black, and 3000-3499* black. 


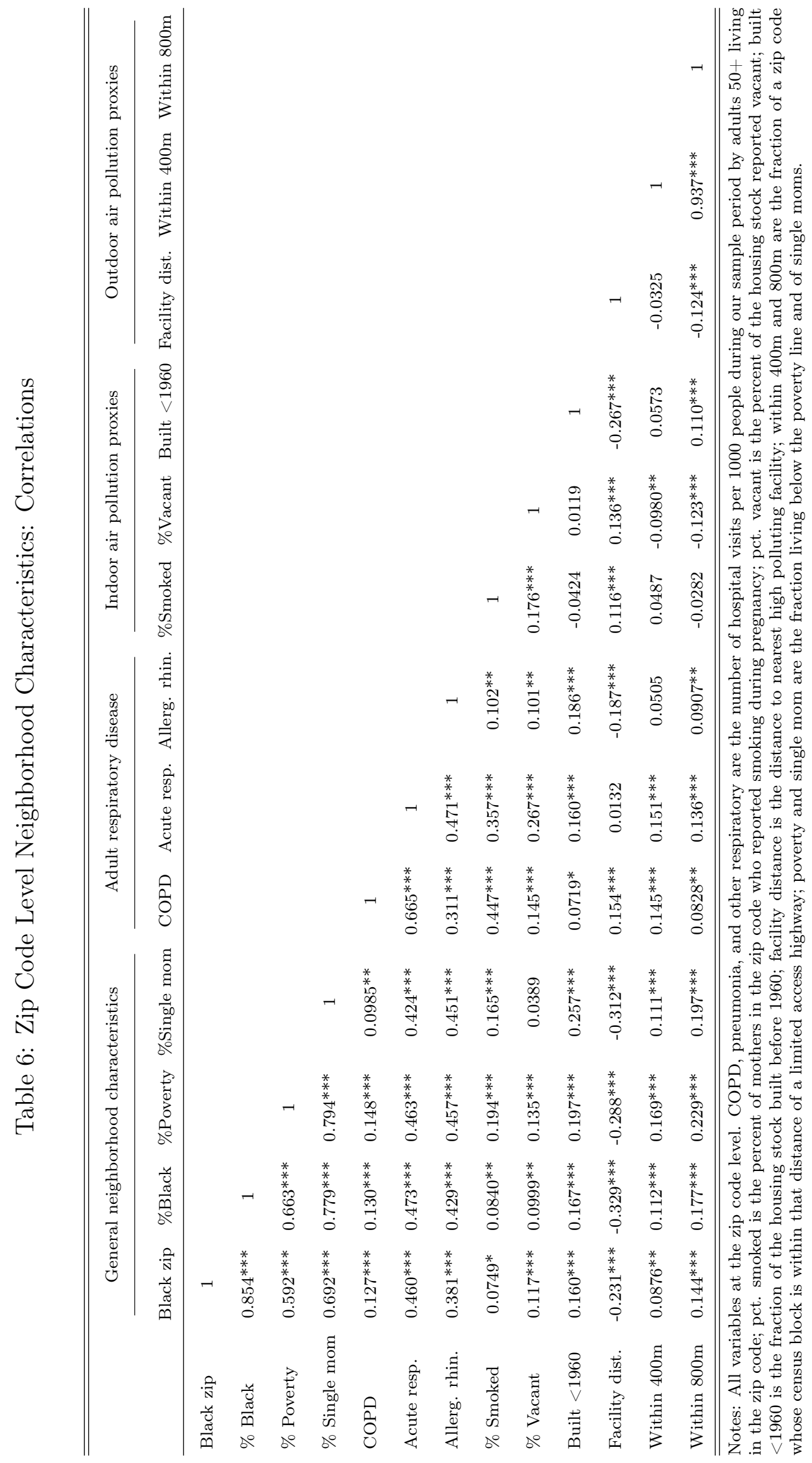




\section{Appendix Figures}

Figure A.1: Pollution Levels by Distance to Black Zip Code: PM 2.5

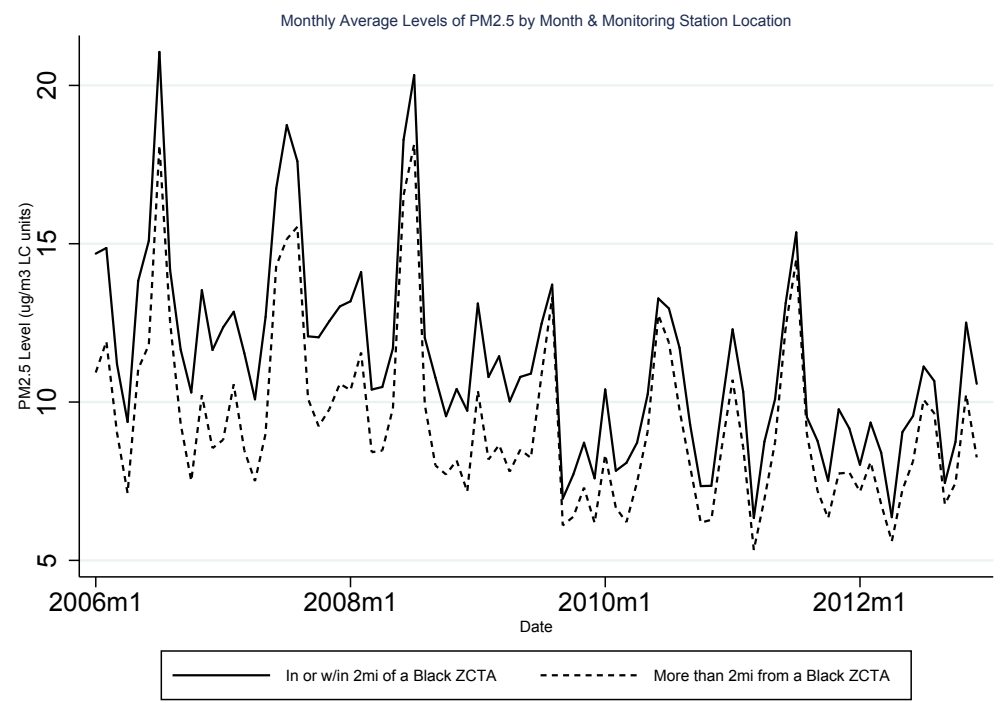

Notes: Black zip codes are zip codes with the highest fraction of black children, up until the point where there are approximately the same number of black children and non-black children in the black zip codes. The remaining zip codes are defined as other zip codes. Black zip codes are mapped to census zip code tabulation areas for calculating distance.

Figure A.2: Pollution Levels by Distance to Black Zip Code: CO

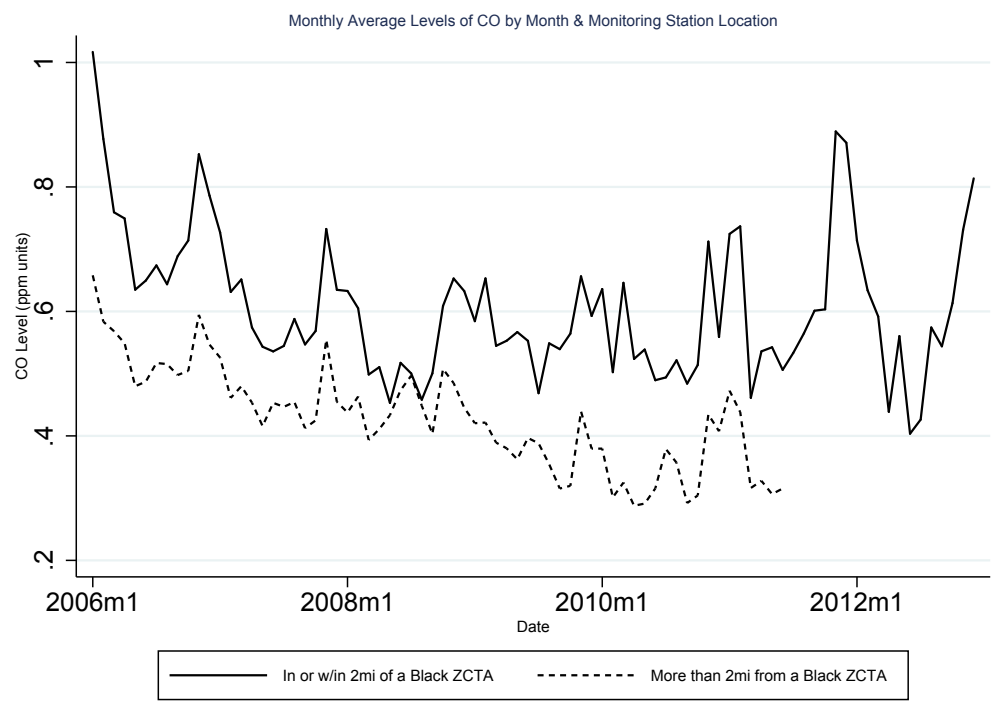

Notes: Black zip codes are zip codes with the highest fraction of black children, up until the point where there are approximately the same number of black children and non-black children in the black zip codes. The remaining zip codes are defined as other zip codes. Black zip codes are mapped to census zip code tabulation areas for calculating distance. 


\section{Figure A.3: Pollution Monitoring Stations: PM 2.5}

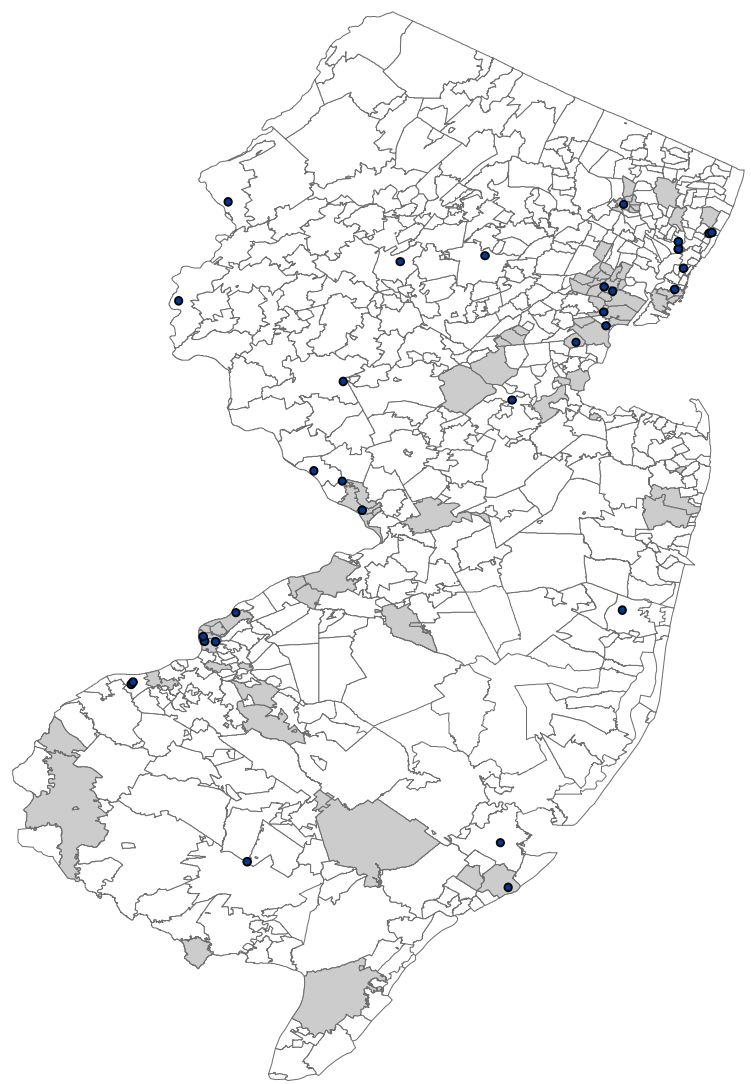

Notes: Grey denotes black zip codes, white denotes other zip codes. Black zip codes are zip codes with the highest fraction of black children, up until the point where there are approximately the same number of black children and non-black children in the black zip codes. The remaining zip codes are defined as other zip codes. As US Postal Service zip codes do not represent contiguous geographic boundaries, we map zip codes to census zip code tabulation areas for the purpose of this figure. 
Figure A.4: Pollution Monitoring Stations: CO

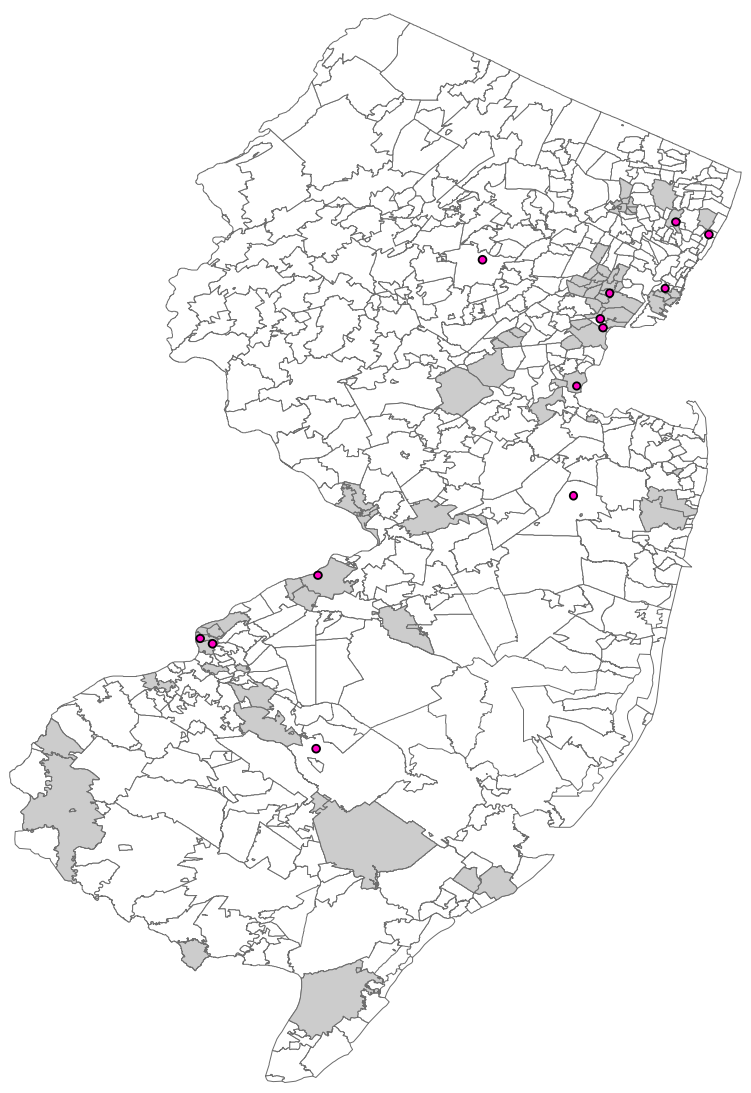

Notes: Grey denotes black zip codes, white denotes other zip codes. Black zip codes are zip codes with the highest fraction of black children, up until the point where there are approximately the same number of black children and non-black children in the black zip codes. The remaining zip codes are defined as other zip codes. As US Postal Service zip codes do not represent contiguous geographic boundaries, we map zip codes to census zip code tabulation areas for the purpose of this figure. 


\section{Figure A.5: NJ Federal and Limited Access Highways}

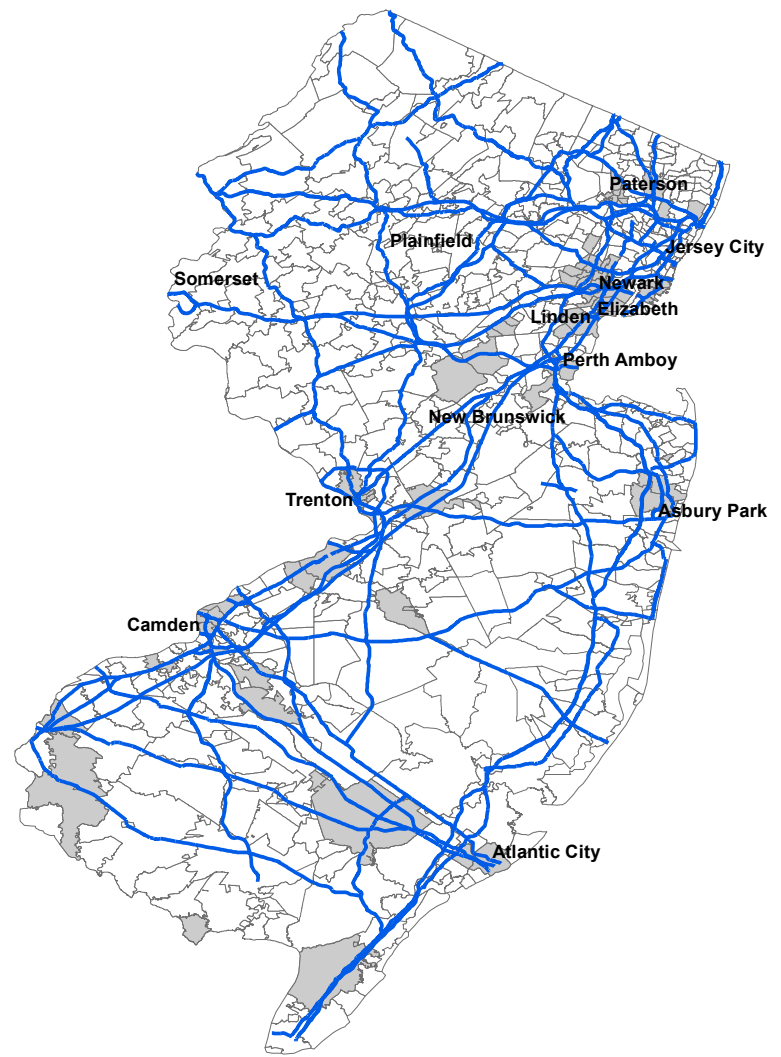

Notes: Grey denotes black zip codes, white denotes other zip codes. Black zip codes are zip codes with the highest fraction of black children, up until the point where there are approximately the same number of black children and non-black children in the black zip codes. The remaining zip codes are defined as other zip codes. As US Postal Service zip codes do not represent contiguous geographic boundaries, we map zip codes to census zip code tabulation areas for the purpose of this figure. 


\section{Appendix Tables}

Table A.1: Asthma and Low Birthweight: by Black Zip Code (22\% Threshold)

\begin{tabular}{|c|c|c|c|c|}
\hline & \multicolumn{2}{|c|}{$\begin{array}{l}\text { Ever Diagnosed with Asthma } \\
\begin{array}{l}(1) \\
\text { Black Zips }\end{array} \quad \text { Other Zips }\end{array}$} & \multicolumn{2}{|c|}{ No. Times Diagnosed with Asthma } \\
\hline $500-999$ & $\begin{array}{c}0.219 * * * \\
(0.030)\end{array}$ & $\begin{array}{c}0.128^{* * * *} \\
(0.013)\end{array}$ & $\begin{array}{c}0.738^{* * * *} \\
(0.202)\end{array}$ & $\begin{array}{c}0.306^{* * * *} \\
(0.045)\end{array}$ \\
\hline $1000-1499$ & $\begin{array}{c}0.128 * * * \\
(0.018)\end{array}$ & $\begin{array}{c}0.076^{* * * *} \\
(0.008)\end{array}$ & $\begin{array}{c}0.450^{* * * *} \\
(0.085)\end{array}$ & $\begin{array}{c}0.157^{* * * *} \\
(0.020)\end{array}$ \\
\hline $1500-1999$ & $\begin{array}{c}0.083^{* * *} \\
(0.012)\end{array}$ & $\begin{array}{c}0.049^{* * * *} \\
(0.005)\end{array}$ & $\begin{array}{c}0.279 * * * \\
(0.052)\end{array}$ & $\begin{array}{c}0.110^{* * *} \\
(0.013)\end{array}$ \\
\hline $2000-2499$ & $\begin{array}{c}0.031 * * * \\
(0.006)\end{array}$ & $\begin{array}{c}0.021^{* * *} \\
(0.002)\end{array}$ & $\begin{array}{c}0.136^{* * *} \\
(0.025)\end{array}$ & $\begin{array}{c}0.055^{* * *} \\
(0.008)\end{array}$ \\
\hline 2500-2999 & $\begin{array}{c}0.016^{* * *} \\
(0.003)\end{array}$ & $\begin{array}{c}0.008^{* * *} \\
(0.001)\end{array}$ & $\begin{array}{c}0.048^{* * *} \\
(0.011)\end{array}$ & $\begin{array}{c}0.018^{* * *} \\
(0.003)\end{array}$ \\
\hline $3500-3999$ & $\begin{array}{l}-0.002 \\
(0.003)\end{array}$ & $\begin{array}{c}-0.003 * * * \\
(0.001)\end{array}$ & $\begin{array}{c}0.001 \\
(0.009)\end{array}$ & $\begin{array}{l}-0.003 \\
(0.003)\end{array}$ \\
\hline $4000-4499$ & $\begin{array}{l}-0.007 \\
(0.005)\end{array}$ & $\begin{array}{c}-0.007^{* * *} \\
(0.002)\end{array}$ & $\begin{array}{c}-0.030^{* *} \\
(0.013)\end{array}$ & $\begin{array}{c}-0.010^{* * *} \\
(0.004)\end{array}$ \\
\hline $4500-4999$ & $\begin{array}{l}0.001 \\
(0.014)\end{array}$ & $\begin{array}{l}-0.005 \\
(0.005)\end{array}$ & $\begin{array}{l}-0.026 \\
(0.030)\end{array}$ & $\begin{array}{l}-0.014 \\
(0.010)\end{array}$ \\
\hline Black & $\begin{array}{c}0.036^{* * *} * \\
(0.003)\end{array}$ & $\begin{array}{c}0.046^{* * *} \\
(0.003)\end{array}$ & $\begin{array}{c}0.088^{* * *} \\
(0.012)\end{array}$ & $\begin{array}{c}0.129^{* * * *} \\
(0.011)\end{array}$ \\
\hline 500-999* black & $\begin{array}{c}0.035 \\
(0.036)\end{array}$ & $\begin{array}{c}0.090^{* *} \\
(0.037)\end{array}$ & $\begin{array}{l}0.165 \\
(0.225)\end{array}$ & $\begin{array}{c}0.583^{* * *} \\
(0.199)\end{array}$ \\
\hline 1000-1499* black & $\begin{array}{c}0.015 \\
(0.024)\end{array}$ & $\begin{array}{c}0.063^{* *} \\
(0.027)\end{array}$ & $\begin{array}{l}0.038 \\
(0.111)\end{array}$ & $\begin{array}{c}0.394^{* * *} \\
(0.129)\end{array}$ \\
\hline 1500-1999* black & $\begin{array}{c}0.009 \\
(0.017)\end{array}$ & $\begin{array}{c}0.017 \\
(0.018)\end{array}$ & $\begin{array}{l}0.120 \\
(0.080)\end{array}$ & $\begin{array}{c}0.196^{* *} \\
(0.087)\end{array}$ \\
\hline $2000-2499 *$ black & $\begin{array}{l}0.010 \\
(0.009)\end{array}$ & $\begin{array}{c}0.021^{* *} \\
(0.010)\end{array}$ & $\begin{array}{c}0.059 \\
(0.040)\end{array}$ & $\begin{array}{l}0.033 \\
(0.034)\end{array}$ \\
\hline $2500-2999 *$ black & $\begin{array}{l}-0.003 \\
(0.005)\end{array}$ & $\begin{array}{l}0.007 \\
(0.006)\end{array}$ & $\begin{array}{l}0.021 \\
(0.020)\end{array}$ & $\begin{array}{l}0.002 \\
(0.020)\end{array}$ \\
\hline $3500-3999 *$ black & $\begin{array}{c}-0.009^{*} \\
(0.005)\end{array}$ & $\begin{array}{l}0.002 \\
(0.006)\end{array}$ & $\begin{array}{l}-0.012 \\
(0.018)\end{array}$ & $\begin{array}{l}0.008 \\
(0.020)\end{array}$ \\
\hline $4000-4499 *$ black & $\begin{array}{l}0.001 \\
(0.009)\end{array}$ & $\begin{array}{l}-0.004 \\
(0.010)\end{array}$ & $\begin{array}{l}0.054 \\
(0.034)\end{array}$ & $\begin{array}{l}-0.016 \\
(0.033)\end{array}$ \\
\hline $4500-4999 *$ black & $\begin{array}{l}-0.021 \\
(0.024)\end{array}$ & $\begin{array}{c}-0.046^{* *} \\
(0.023)\end{array}$ & $\begin{array}{l}-0.035 \\
(0.071)\end{array}$ & $\begin{array}{c}-0.136^{* * *} \\
(0.049)\end{array}$ \\
\hline $\begin{array}{l}\text { Individual/census vars } \\
\text { Hospital fixed effects }\end{array}$ & $\begin{array}{l}\mathrm{x} \\
\mathrm{x}\end{array}$ & $\begin{array}{l}\mathrm{x} \\
\mathrm{x}\end{array}$ & $\begin{array}{l}\mathrm{x} \\
\mathrm{x}\end{array}$ & $\begin{array}{l}\mathrm{x} \\
\mathrm{x}\end{array}$ \\
\hline $\begin{array}{l}\text { Observations } \\
\text { R-squared } \\
\text { Mean dep. var. } \\
\text { Clusters } \\
\text { F-statistic } \\
\text { P-value }\end{array}$ & $\begin{array}{c}117,137 \\
0.071 \\
0.138 \\
101,568 \\
0.646 \\
0.630\end{array}$ & $\begin{array}{c}329,015 \\
0.047 \\
0.065 \\
270,630 \\
3.851 \\
0.004\end{array}$ & $\begin{array}{c}117,137 \\
0.057 \\
0.336 \\
101,568 \\
1.184 \\
0.315\end{array}$ & $\begin{array}{c}329,015 \\
0.041 \\
0.123 \\
270,630 \\
5.842 \\
0.000\end{array}$ \\
\hline
\end{tabular}

Notes: Other included controls: other race, mother smoked during pregnancy, mother's education (in years: 0-11, 12, 13-16, 16+), mother's age ( $<20,20-24,25-29,30-34,35+)$, mother married at birth, sex, birth order $(1,2,3,4+)$, multiple birth indicator, indicator for other race (non-white, non-black), indicator for child ever used public insurance, and dummy variables for child's age at end of sample in quarters; zip code level variables: population, population density, median age, average household size, pct. with less than high school $(25+)$, pct. with bachelor's degree or more $(25+)$, pct. in labor force $(16+)$, pct. of households making $<20 \mathrm{k}$, pct. of households making $>200 \mathrm{k}$, median year structure built, pct. of housing owner occupied, pct. of housing vacant, median value of owner occupied housing, pct. of families below poverty. F-statistic/Pvalue from a test that the coefficients on the first 4 birthweight bins interacted with black are jointly equal to zero. Standard errors clustered at mother. The omitted categories are 3000-3499 and 3000-3499* black. 
Table A.2: Asthma and Low Birth Weight: by Black Zip Codes, with Mother Fixed Effects (22\% Threshold)

\begin{tabular}{|c|c|c|c|c|}
\hline & \multicolumn{2}{|c|}{$\begin{array}{l}\text { Ever Diagnosed with Asthma } \\
\begin{array}{l}(1) \\
\text { Black Zips }\end{array} \quad \text { Other Zips }\end{array}$} & \multicolumn{2}{|c|}{$\begin{array}{l}\text { No. Times Diagnosed with Asthma } \\
(3)\end{array}$} \\
\hline $500-999$ & $\begin{array}{c}0.237^{* * *} \\
(0.077)\end{array}$ & $\begin{array}{c}0.116^{* * *} \\
(0.031)\end{array}$ & $\begin{array}{l}1.439^{*} \\
(0.789)\end{array}$ & $\begin{array}{c}0.432^{* * *} \\
(0.118)\end{array}$ \\
\hline 1000-1499 & $\begin{array}{c}0.141^{* * *} \\
(0.041)\end{array}$ & $\begin{array}{c}0.066^{* * *} \\
(0.015)\end{array}$ & $\begin{array}{c}0.661^{* * *} \\
(0.212)\end{array}$ & $\begin{array}{c}0.174^{* * *} \\
(0.035)\end{array}$ \\
\hline 1500-1999 & $\begin{array}{c}0.115^{* * *} \\
(0.031)\end{array}$ & $\begin{array}{c}0.035^{* * *} \\
(0.009)\end{array}$ & $\begin{array}{c}0.367^{* * *} \\
(0.130)\end{array}$ & $\begin{array}{c}0.100^{* * *} * \\
(0.024)\end{array}$ \\
\hline 2000-2499 & $\begin{array}{c}0.018 \\
(0.015)\end{array}$ & $\begin{array}{c}0.012^{* *} \\
(0.005)\end{array}$ & $\begin{array}{c}0.132 * * \\
(0.061)\end{array}$ & $\begin{array}{c}0.027 * * \\
(0.013)\end{array}$ \\
\hline 2500-2999 & $\begin{array}{c}0.026^{* * *} \\
(0.010)\end{array}$ & $\begin{array}{l}0.006^{*} \\
(0.003)\end{array}$ & $\begin{array}{c}0.110^{* * * *} \\
(0.035)\end{array}$ & $\begin{array}{l}0.011 \\
(0.007)\end{array}$ \\
\hline 3500-3999 & $\begin{array}{c}0.014 \\
(0.008)\end{array}$ & $\begin{array}{l}-0.002 \\
(0.002)\end{array}$ & $\begin{array}{c}0.066^{* *} \\
(0.030)\end{array}$ & $\begin{array}{l}-0.008 \\
(0.005)\end{array}$ \\
\hline $4000-4499$ & $\begin{array}{c}0.004 \\
(0.014)\end{array}$ & $\begin{array}{r}-0.007^{*} \\
(0.004)\end{array}$ & $\begin{array}{l}0.007 \\
(0.043)\end{array}$ & $\begin{array}{l}-0.011 \\
(0.008)\end{array}$ \\
\hline $4500-4999$ & $\begin{array}{l}-0.005 \\
(0.039)\end{array}$ & $\begin{array}{l}-0.008 \\
(0.010)\end{array}$ & $\begin{array}{c}0.052 \\
(0.098)\end{array}$ & $\begin{array}{l}-0.033 \\
(0.022)\end{array}$ \\
\hline $500-999 *$ black & $\begin{array}{c}0.014 \\
(0.088)\end{array}$ & $\begin{array}{l}-0.058 \\
(0.108)\end{array}$ & $\begin{array}{l}-0.240 \\
(0.821)\end{array}$ & $\begin{array}{l}-0.109 \\
(0.388)\end{array}$ \\
\hline 1000-1499* black & $\begin{array}{l}-0.002 \\
(0.057)\end{array}$ & $\begin{array}{l}-0.062 \\
(0.068)\end{array}$ & $\begin{array}{l}-0.034 \\
(0.289)\end{array}$ & $\begin{array}{l}-0.100 \\
(0.160)\end{array}$ \\
\hline 1500-1999* black & $\begin{array}{l}-0.020 \\
(0.041)\end{array}$ & $\begin{array}{c}0.043 \\
(0.041)\end{array}$ & $\begin{array}{c}0.121 \\
(0.201)\end{array}$ & $\begin{array}{c}0.194 \\
(0.152)\end{array}$ \\
\hline 2000-2499* black & $\begin{array}{c}0.016 \\
(0.023)\end{array}$ & $\begin{array}{c}0.021 \\
(0.025)\end{array}$ & $\begin{array}{c}0.046 \\
(0.096)\end{array}$ & $\begin{array}{c}0.046 \\
(0.090)\end{array}$ \\
\hline $2500-2999 *$ black & $\begin{array}{l}-0.023 \\
(0.015)\end{array}$ & $\begin{array}{c}0.008 \\
(0.015)\end{array}$ & $\begin{array}{c}-0.099^{*} \\
(0.053)\end{array}$ & $\begin{array}{c}0.017 \\
(0.047)\end{array}$ \\
\hline 3500-3999* black & $\begin{array}{c}-0.030^{* *} \\
(0.014)\end{array}$ & $\begin{array}{c}0.034^{* *} \\
(0.015)\end{array}$ & $\begin{array}{l}-0.068 \\
(0.050)\end{array}$ & $\begin{array}{c}0.073 \\
(0.053)\end{array}$ \\
\hline 4000-4499* black & $\begin{array}{l}-0.004 \\
(0.027)\end{array}$ & $\begin{array}{l}-0.007 \\
(0.029)\end{array}$ & $\begin{array}{c}0.080 \\
(0.088)\end{array}$ & $\begin{array}{l}-0.042 \\
(0.087)\end{array}$ \\
\hline $4500-4999 *$ black & $\begin{array}{l}-0.036 \\
(0.077)\end{array}$ & $\begin{array}{c}0.043 \\
(0.061)\end{array}$ & $\begin{array}{l}-0.208 \\
(0.179)\end{array}$ & $\begin{array}{c}0.177 \\
(0.121)\end{array}$ \\
\hline Individual/census vars & $\mathrm{x}$ & $\mathrm{x}$ & $\mathrm{x}$ & $\mathrm{x}$ \\
\hline Hospital fixed effects & $\mathrm{x}$ & $\mathrm{x}$ & $\mathrm{x}$ & $\mathrm{x}$ \\
\hline Mother fixed effects & $\mathrm{x}$ & $\mathrm{x}$ & $\mathrm{x}$ & $\mathrm{x}$ \\
\hline Observations & 117,137 & 329,015 & 117,137 & 329,015 \\
\hline R-squared & 0.045 & 0.018 & 0.039 & 0.016 \\
\hline Mean dep. var. & 0.084 & 0.084 & 0.179 & 0.179 \\
\hline Clusters & 101,568 & 270,630 & 101,568 & 270,630 \\
\hline F-statistic & 0.261 & 0.829 & 0.176 & 0.695 \\
\hline $\mathrm{P}$-value & 0.903 & 0.506 & 0.951 & 0.595 \\
\hline
\end{tabular}

Notes: Other included controls: other race, mother smoked during pregnancy, mother's education (in years: 0-11, 12, 13-16, 16+), mother's age $(<20,20-24,25-29,30-34,35+)$, mother married at birth, sex, birth order $(1,2,3,4+)$, multiple birth indicator, indicator for other race (non-white, non-black), indicator for child ever used public insurance, and dummy variables for child's age at end of sample in quarters; zip code level variables: population, population density, median age, average household size, pct. with less than high school $(25+)$, pct. with bachelor's degree or more $(25+)$, pct. in labor force $(16+)$, pct. of households making $<20 \mathrm{k}$, pct. of households making $>200 \mathrm{k}$, median year structure built, pct. of housing owner occupied, pct. of housing vacant, median value of owner occupied housing, pct. of families below poverty. F-statistic/P-value from a test that the coefficients on the first 4 birthweight bins interacted with black are jointly equal to zero. Standard errors clustered at mother. The omitted categories are 3000-3499, black, and $3000-3499 *$ black. 
Table A.3: Asthma and Low Birthweight: by Black Zip Code (32\% Threshold)

\begin{tabular}{|c|c|c|c|c|}
\hline & \multicolumn{2}{|c|}{$\begin{array}{l}\text { Ever Diagnosed with Asthma } \\
\begin{array}{l}(1) \\
\text { Black Zips }\end{array}\end{array}$} & \multicolumn{2}{|c|}{$\begin{array}{l}\text { No. Times Diagnosed with Asthma } \\
\text { (3) } \\
\text { Black Zips }\end{array}$} \\
\hline 500-999 & $\begin{array}{c}0.262^{* * *} \\
(0.045)\end{array}$ & $\begin{array}{c}0.136^{* * *} \\
(0.013)\end{array}$ & $\begin{array}{c}1.137^{* * *} \\
(0.415)\end{array}$ & $\begin{array}{c}0.319 * * * \\
(0.042)\end{array}$ \\
\hline 1000-1499 & $\begin{array}{c}0.121^{* * * *} \\
(0.027)\end{array}$ & $\begin{array}{c}0.085^{* * * *} \\
(0.008)\end{array}$ & $\begin{array}{c}0.579 * * * \\
(0.141)\end{array}$ & $\begin{array}{c}0.187^{* * * *} \\
(0.022)\end{array}$ \\
\hline 1500-1999 & $\begin{array}{c}0.110^{* * * *} \\
(0.019)\end{array}$ & $\begin{array}{c}0.050 * * * \\
(0.005)\end{array}$ & $\begin{array}{c}0.362^{* * *} \\
(0.089)\end{array}$ & $\begin{array}{c}0.123^{* * *} * \\
(0.013)\end{array}$ \\
\hline 2000-2499 & $\begin{array}{c}0.036^{* * * *} \\
(0.010)\end{array}$ & $\begin{array}{c}0.022^{* * *} \\
(0.002)\end{array}$ & $\begin{array}{c}0.154^{* * * *} \\
(0.039)\end{array}$ & $\begin{array}{c}0.064^{* * *} \\
(0.008)\end{array}$ \\
\hline 2500-2999 & $\begin{array}{c}0.023^{* * * *} \\
(0.005)\end{array}$ & $\begin{array}{c}0.008^{* * * *} \\
(0.001)\end{array}$ & $\begin{array}{c}0.064^{* * *} \\
(0.018)\end{array}$ & $\begin{array}{c}0.020^{* * *} * \\
(0.003)\end{array}$ \\
\hline 3500-3999 & $\begin{array}{l}-0.003 \\
(0.005)\end{array}$ & $\begin{array}{c}-0.003^{* * *} * \\
(0.001)\end{array}$ & $\begin{array}{c}0.004 \\
(0.016)\end{array}$ & $\begin{array}{l}-0.003 \\
(0.003)\end{array}$ \\
\hline $4000-4499$ & $\begin{array}{l}-0.004 \\
(0.008)\end{array}$ & $\begin{array}{c}-0.007^{* * *} \\
(0.002)\end{array}$ & $\begin{array}{r}-0.038^{*} \\
(0.021)\end{array}$ & $\begin{array}{c}-0.012^{* * *} \\
(0.004)\end{array}$ \\
\hline $4500-4999$ & $\begin{array}{c}0.010 \\
(0.024)\end{array}$ & $\begin{array}{l}-0.006 \\
(0.004)\end{array}$ & $\begin{array}{l}-0.016 \\
(0.057)\end{array}$ & $\begin{array}{r}-0.017^{*} \\
(0.009)\end{array}$ \\
\hline Black & $\begin{array}{c}0.039^{* * * *} \\
(0.005)\end{array}$ & $\begin{array}{c}0.043^{* * * *} \\
(0.003)\end{array}$ & $\begin{array}{c}0.112^{* * * *} \\
(0.016)\end{array}$ & $\begin{array}{c}0.114^{* * *} \\
(0.009)\end{array}$ \\
\hline $500-999 *$ black & $\begin{array}{c}0.002 \\
(0.050)\end{array}$ & $\begin{array}{c}0.088^{* * * *} \\
(0.029)\end{array}$ & $\begin{array}{l}-0.153 \\
(0.432)\end{array}$ & $\begin{array}{c}0.462^{* * * *} \\
(0.133)\end{array}$ \\
\hline 1000-1499* black & $\begin{array}{c}0.029 \\
(0.033)\end{array}$ & $\begin{array}{c}0.046^{* *} \\
(0.021)\end{array}$ & $\begin{array}{c}-0.058 \\
(0.164)\end{array}$ & $\begin{array}{c}0.291^{* * * *} \\
(0.095)\end{array}$ \\
\hline 1500-1999* black & $\begin{array}{l}-0.017 \\
(0.024)\end{array}$ & $\begin{array}{c}0.023 \\
(0.015)\end{array}$ & $\begin{array}{c}0.061 \\
(0.114)\end{array}$ & $\begin{array}{c}0.175^{* * * *} \\
(0.068)\end{array}$ \\
\hline 2000-2499* black & $\begin{array}{c}0.004 \\
(0.013)\end{array}$ & $\begin{array}{c}0.020^{* *} \\
(0.008)\end{array}$ & $\begin{array}{c}0.049 \\
(0.056)\end{array}$ & $\begin{array}{l}0.047^{*} \\
(0.028)\end{array}$ \\
\hline $2500-2999 *$ black & $\begin{array}{l}-0.011 \\
(0.007)\end{array}$ & $\begin{array}{c}0.007 \\
(0.005)\end{array}$ & $\begin{array}{c}0.009 \\
(0.027)\end{array}$ & $\begin{array}{c}0.012 \\
(0.016)\end{array}$ \\
\hline 3500-3999* black & $\begin{array}{l}-0.010 \\
(0.007)\end{array}$ & $\begin{array}{c}0.002 \\
(0.005)\end{array}$ & $\begin{array}{l}-0.009 \\
(0.025)\end{array}$ & $\begin{array}{c}0.001 \\
(0.016)\end{array}$ \\
\hline 4000-4499* black & $\begin{array}{c}0.001 \\
(0.012)\end{array}$ & $\begin{array}{l}-0.004 \\
(0.008)\end{array}$ & $\begin{array}{l}0.076^{*} \\
(0.046)\end{array}$ & $\begin{array}{l}-0.008 \\
(0.026)\end{array}$ \\
\hline $4500-4999 *$ black & $\begin{array}{l}-0.031 \\
(0.034)\end{array}$ & $\begin{array}{l}-0.034^{*} \\
(0.020)\end{array}$ & $\begin{array}{l}-0.045 \\
(0.099)\end{array}$ & $\begin{array}{c}-0.096^{* *} \\
(0.043)\end{array}$ \\
\hline Individual/census vars & $\mathrm{x}$ & $\mathrm{x}$ & $\mathrm{x}$ & $\mathrm{x}$ \\
\hline Hospital fixed effects & $\mathrm{x}$ & $\mathrm{x}$ & $\mathrm{x}$ & $\mathrm{x}$ \\
\hline $\begin{array}{l}\text { Observations } \\
\text { R-squared } \\
\text { Mean dep. var. } \\
\text { Clusters } \\
\text { F-statistic } \\
\text { P-value }\end{array}$ & $\begin{array}{c}69,177 \\
0.069 \\
0.162 \\
60,302 \\
0.368 \\
0.832\end{array}$ & $\begin{array}{c}376,975 \\
0.050 \\
0.070 \\
310,887 \\
5.189 \\
0.000\end{array}$ & $\begin{array}{c}69,177 \\
0.056 \\
0.416 \\
60,302 \\
0.322 \\
0.863\end{array}$ & $\begin{array}{c}376,975 \\
0.042 \\
0.136 \\
310,887 \\
7.486 \\
0.000\end{array}$ \\
\hline
\end{tabular}

Notes: Other included controls: other race, mother smoked during pregnancy, mother's education (in years: 0-11, 12, 13-16, 16+), mother's age ( $<20,20-24,25-29,30-34,35+)$, mother married at birth, sex, birth order $(1,2,3,4+)$, multiple birth indicator, indicator for other race (non-white, non-black), indicator for child ever used public insurance, and dummy variables for child's age at end of sample in quarters; zip code level variables: population, population density, median age, average household size, pct. with less than high school $(25+)$, pct. with bachelor's degree or more $(25+)$, pct. in labor force $(16+)$, pct. of households making $<20 \mathrm{k}$, pct. of households making $>200 \mathrm{k}$, median year structure built, pct. of housing owner occupied, pct. of housing vacant, median value of owner occupied housing, pct. of families below poverty. F-statistic/Pvalue from a test that the coefficients on the first 4 birthweight bins interacted with black are jointly equal to zero. Standard errors clustered at mother. The omitted categories are 3000-3499 and 3000-3499* black. 
Table A.4: Asthma and Low Birth Weight: by Black Zip Codes, with Mother Fixed Effects (32\% Threshold)

\begin{tabular}{|c|c|c|c|c|}
\hline & \multicolumn{2}{|c|}{$\begin{array}{l}\text { Ever Diagnosed with Asthma } \\
\begin{array}{l}(1) \\
\text { Black Zips }\end{array} \\
(2) \\
\text { Other Zips }\end{array}$} & \multicolumn{2}{|c|}{ No. Times Diagnosed with Asthma } \\
\hline 500-999 & $\begin{array}{c}0.356^{* * *} \\
(0.121)\end{array}$ & $\begin{array}{c}0.100 * * * \\
(0.030)\end{array}$ & $\begin{array}{c}3.288 \\
(2.124)\end{array}$ & $\begin{array}{c}0.386^{* * *} \\
(0.104)\end{array}$ \\
\hline $1000-1499$ & $\begin{array}{l}0.123^{*} \\
(0.067)\end{array}$ & $\begin{array}{c}0.072^{* * *} \\
(0.015)\end{array}$ & $\begin{array}{l}0.887^{* *} \\
(0.405)\end{array}$ & $\begin{array}{c}0.194^{* * *} * \\
(0.036)\end{array}$ \\
\hline $1500-1999$ & $\begin{array}{c}0.198^{* * * *} \\
(0.048)\end{array}$ & $\begin{array}{c}0.033^{* * *} \\
(0.009)\end{array}$ & $\begin{array}{c}0.519^{* * * *} \\
(0.182)\end{array}$ & $\begin{array}{c}0.104^{* * * *} \\
(0.026)\end{array}$ \\
\hline $2000-2499$ & $\begin{array}{c}0.023 \\
(0.025)\end{array}$ & $\begin{array}{l}0.012^{* *} \\
(0.005)\end{array}$ & $\begin{array}{c}0.236^{* *} \\
(0.121)\end{array}$ & $\begin{array}{c}0.029^{* *} \\
(0.013)\end{array}$ \\
\hline 2500-2999 & $\begin{array}{l}0.029^{*} \\
(0.016)\end{array}$ & $\begin{array}{c}0.006^{* *} \\
(0.003)\end{array}$ & $\begin{array}{l}0.150^{* *} \\
(0.065)\end{array}$ & $\begin{array}{l}0.014^{* *} \\
(0.007)\end{array}$ \\
\hline 3500-3999 & $\begin{array}{l}0.007 \\
(0.013)\end{array}$ & $\begin{array}{l}-0.001 \\
(0.002)\end{array}$ & $\begin{array}{c}0.071 \\
(0.053)\end{array}$ & $\begin{array}{l}-0.005 \\
(0.005)\end{array}$ \\
\hline $4000-4499$ & $\begin{array}{c}0.009 \\
(0.023)\end{array}$ & $\begin{array}{l}-0.005 \\
(0.004)\end{array}$ & $\begin{array}{l}-0.021 \\
(0.070)\end{array}$ & $\begin{array}{l}-0.008 \\
(0.009)\end{array}$ \\
\hline $4500-4999$ & $\begin{array}{l}-0.066 \\
(0.075)\end{array}$ & $\begin{array}{l}-0.007 \\
(0.010)\end{array}$ & $\begin{array}{l}-0.097 \\
(0.194)\end{array}$ & $\begin{array}{l}-0.024 \\
-(0.022)\end{array}$ \\
\hline $500-999 *$ black & $\begin{array}{l}-0.063 \\
(0.132)\end{array}$ & $\begin{array}{l}0.018 \\
(0.075)\end{array}$ & $\begin{array}{l}-1.772 \\
(2.136)\end{array}$ & $\begin{array}{c}0.182 \\
(0.279)\end{array}$ \\
\hline 1000-1499* black & $\begin{array}{c}0.034 \\
(0.080)\end{array}$ & $\begin{array}{l}-0.040 \\
(0.054)\end{array}$ & $\begin{array}{l}-0.074 \\
(0.470)\end{array}$ & $\begin{array}{l}-0.111 \\
(0.142)\end{array}$ \\
\hline 1500-1999* black & $\begin{array}{l}-0.089 \\
(0.058)\end{array}$ & $\begin{array}{c}0.038 \\
(0.033)\end{array}$ & $\begin{array}{c}0.011 \\
(0.263)\end{array}$ & $\begin{array}{c}0.193 \\
(0.139)\end{array}$ \\
\hline $2000-2499 *$ black & $\begin{array}{c}0.022 \\
(0.033)\end{array}$ & $\begin{array}{c}0.012 \\
(0.020)\end{array}$ & $\begin{array}{l}-0.038 \\
(0.156)\end{array}$ & $\begin{array}{c}0.066 \\
(0.068)\end{array}$ \\
\hline $2500-2999 *$ black & $\begin{array}{l}-0.014 \\
(0.021)\end{array}$ & $\begin{array}{l}-0.006 \\
(0.012)\end{array}$ & $\begin{array}{l}-0.121 \\
(0.082)\end{array}$ & $\begin{array}{c}0.003 \\
(0.040)\end{array}$ \\
\hline $3500-3999 *$ black & $\begin{array}{l}-0.019 \\
(0.020)\end{array}$ & $\begin{array}{l}0.024^{* *} \\
(0.012)\end{array}$ & $\begin{array}{l}-0.059 \\
(0.071)\end{array}$ & $\begin{array}{c}0.031 \\
(0.041)\end{array}$ \\
\hline $4000-4499 *$ black & $\begin{array}{c}0.000 \\
(0.035)\end{array}$ & $\begin{array}{l}-0.002 \\
(0.023)\end{array}$ & $\begin{array}{c}0.171 \\
(0.118)\end{array}$ & $\begin{array}{l}-0.025 \\
(0.070)\end{array}$ \\
\hline $4500-4999 *$ black & $\begin{array}{c}0.046 \\
(0.111)\end{array}$ & $\begin{array}{c}0.032 \\
(0.046)\end{array}$ & $\begin{array}{l}-0.040 \\
(0.264)\end{array}$ & $\begin{array}{c}0.125 \\
(0.092)\end{array}$ \\
\hline Individual/census vars & $\mathrm{x}$ & $\mathrm{x}$ & $\mathrm{x}$ & $\mathrm{x}$ \\
\hline $\begin{array}{l}\text { Hospital fixed effects } \\
\text { Mother fixed effects }\end{array}$ & $\begin{array}{l}\mathrm{x} \\
\mathrm{x}\end{array}$ & $\begin{array}{l}\mathrm{x} \\
\mathrm{x}\end{array}$ & $\begin{array}{l}\mathrm{x} \\
\mathrm{x}\end{array}$ & $\begin{array}{l}\mathrm{x} \\
\mathrm{x}\end{array}$ \\
\hline $\begin{array}{l}\text { Observations } \\
\text { R-squared } \\
\text { Mean dep. var. } \\
\text { Clusters } \\
\text { F-statistic } \\
\text { P-value }\end{array}$ & $\begin{array}{c}69,177 \\
0.056 \\
0.084 \\
60,302 \\
1.089 \\
0.360\end{array}$ & $\begin{array}{c}376,975 \\
0.018 \\
0.084 \\
310,887 \\
0.687 \\
0.601\end{array}$ & $\begin{array}{l}69,177 \\
0.052 \\
0.179 \\
60,302 \\
0.222 \\
0.926\end{array}$ & $\begin{array}{c}376,975 \\
0.017 \\
0.179 \\
310,887 \\
1.129 \\
0.341\end{array}$ \\
\hline
\end{tabular}

Notes: Other included controls: other race, mother smoked during pregnancy, mother's education (in years: $0-11,12,13-16,16+)$, mother's age $(<20,20-24,25-29,30-34,35+)$, mother married at birth, sex, birth order $(1,2,3,4+)$, multiple birth indicator, indicator for other race (non-white, non-black), indicator for child ever used public insurance, and dummy variables for child's age at end of sample in quarters; zip code level variables: population, population density, median age, average household size, pct. with less than high school $(25+)$, pct. with bachelor's degree or more $(25+)$, pct. in labor force $(16+)$, pct. of households making $<20 \mathrm{k}$, pct. of households making $>200 \mathrm{k}$, median year structure built, pct. of housing owner occupied, pct. of housing vacant, median value of owner occupied housing, pct. of families below poverty. F-statistic/P-value from a test that the coefficients on the first 4 birthweight bins interacted with black are jointly equal to zero. Standard errors clustered at mother. The omitted categories are 3000-3499, black, and $3000-3499 *$ black. 
Table A.5: Total Number of Visits for Asthma and Low Birth Weight: Zero-Inflated Negative Binomial Models

\begin{tabular}{|c|c|c|c|c|}
\hline & $\begin{array}{c}(1) \\
\text { Baseline }\end{array}$ & With $\stackrel{(2)}{\text { Controls }}$ & $\begin{array}{c}(3) \\
\text { Black Zips }\end{array}$ & $\begin{array}{c}(4) \\
\text { Other Zips }\end{array}$ \\
\hline $500-999$ & $\begin{array}{c}0.641^{* * * *} \\
(0.114)\end{array}$ & $\begin{array}{c}0.957^{* * * *} \\
(0.094)\end{array}$ & $\begin{array}{c}1.062^{* * * *} \\
(0.165)\end{array}$ & $\begin{array}{c}1.031^{* * *} \\
(0.116)\end{array}$ \\
\hline 1000-1499 & $\begin{array}{c}0.372^{* * * *} \\
(0.107)\end{array}$ & $\begin{array}{c}0.561^{* * * *} \\
(0.075)\end{array}$ & $\begin{array}{c}0.706^{* * *} * \\
(0.164)\end{array}$ & $\begin{array}{c}0.583 * * * \\
(0.089)\end{array}$ \\
\hline $1500-1999$ & $\begin{array}{c}0.317^{* * * *} \\
(0.090)\end{array}$ & $\begin{array}{c}0.356^{* * *} \\
(0.091)\end{array}$ & $\begin{array}{c}0.485^{* * *} \\
(0.163)\end{array}$ & $\begin{array}{c}0.355^{* * *} \\
(0.108)\end{array}$ \\
\hline $2000-2499$ & $\begin{array}{c}0.316^{* * *} \\
(0.068)\end{array}$ & $\begin{array}{c}0.257^{* * * *} \\
(0.067)\end{array}$ & $\begin{array}{l}0.231^{*} \\
(0.127)\end{array}$ & $\begin{array}{c}0.258^{* * *} \\
(0.077)\end{array}$ \\
\hline $2500-2999$ & $\begin{array}{c}0.099^{* *} \\
(0.040)\end{array}$ & $\begin{array}{l}0.071^{*} \\
(0.043)\end{array}$ & $\begin{array}{l}-0.018 \\
(0.081)\end{array}$ & $0.115^{* *}$ \\
\hline 3500-3999 & $\begin{array}{c}0.024 \\
(0.037)\end{array}$ & $\begin{array}{l}-0.010 \\
(0.037)\end{array}$ & $\begin{array}{l}(0.081) \\
-0.009 \\
(0.078)\end{array}$ & $\begin{array}{l}-0.011 \\
-(0.042)\end{array}$ \\
\hline $4000-4499$ & $\begin{array}{l}-0.060 \\
(0.059)\end{array}$ & $\begin{array}{l}-0.010 \\
(0.062)\end{array}$ & $\begin{array}{l}-0.139 \\
(0.118)\end{array}$ & $\begin{array}{c}0.016 \\
(0.071)\end{array}$ \\
\hline $4500-4999$ & $\begin{array}{l}-0.190 \\
(0.136)\end{array}$ & $\begin{array}{c}0.011 \\
(0.146)\end{array}$ & $\begin{array}{c}0.075 \\
(0.343)\end{array}$ & $\begin{array}{c}0.021 \\
(0.164)\end{array}$ \\
\hline Black & $\begin{array}{c}0.534^{* * * *} \\
(0.036)\end{array}$ & $\begin{array}{c}0.155^{* * * *} \\
(0.040)\end{array}$ & $\begin{array}{c}0.024 \\
(0.062)\end{array}$ & $\begin{array}{c}0.381^{* * *} \\
(0.064)\end{array}$ \\
\hline 500-999* black & $\begin{array}{c}0.341^{* * *} * \\
(0.131)\end{array}$ & $\begin{array}{c}0.365^{* * *} * \\
(0.127)\end{array}$ & $\begin{array}{l}0.170 \\
(0.187)\end{array}$ & $\begin{array}{c}0.312 \\
(0.202)\end{array}$ \\
\hline $1000-1499 *$ black & $\begin{array}{c}0.270^{* *} \\
(0.132)\end{array}$ & $\begin{array}{c}0.244^{* *} \\
(0.109)\end{array}$ & $\begin{array}{l}-0.023 \\
(0.187)\end{array}$ & $\begin{array}{l}0.346^{*} \\
(0.186)\end{array}$ \\
\hline $1500-1999 *$ black & $\begin{array}{c}0.156 \\
(0.127)\end{array}$ & $\begin{array}{l}0.265^{* *} \\
(0.119)\end{array}$ & $\begin{array}{c}0.194 \\
(0.198)\end{array}$ & $\begin{array}{c}(0.160) \\
0.164 \\
(0.173)\end{array}$ \\
\hline 2000-2499* black & $\begin{array}{l}-0.070 \\
(0.096)\end{array}$ & $\begin{array}{c}0.027 \\
(0.088)\end{array}$ & $\begin{array}{l}0.088 \\
(0.150)\end{array}$ & $\begin{array}{l}-0.015 \\
(0.128)\end{array}$ \\
\hline $2500-2999 *$ black & $\begin{array}{c}0.024 \\
(0.060)\end{array}$ & $\begin{array}{c}0.058 \\
(0.065)\end{array}$ & $\begin{array}{l}0.230^{* *} \\
(0.100)\end{array}$ & $\begin{array}{l}-0.078 \\
(0.094)\end{array}$ \\
\hline $3500-3999 *$ black & $\begin{array}{l}0.016 \\
(0.062)\end{array}$ & $\begin{array}{c}0.083 \\
(0.066)\end{array}$ & $\begin{array}{l}0.114 \\
(0.100)\end{array}$ & $\begin{array}{l}0.005 \\
(0.109)\end{array}$ \\
\hline $4000-4499 *$ black & $\begin{array}{c}0.132 \\
(0.112)\end{array}$ & $\begin{array}{c}0.163 \\
(0.123)\end{array}$ & $\begin{array}{l}0.346^{* *} \\
(0.166)\end{array}$ & $\begin{array}{l}0.143 \\
(0.226)\end{array}$ \\
\hline $4500-4999 *$ black & $\begin{array}{c}0.020 \\
(0.297)\end{array}$ & $\begin{array}{l}-0.282 \\
(0.309)\end{array}$ & $\begin{array}{l}-0.222 \\
(0.433)\end{array}$ & $\begin{array}{l}-0.084 \\
(0.949)\end{array}$ \\
\hline $\begin{array}{l}\text { Individual/census vars } \\
\text { Hospital fixed effects }\end{array}$ & - & $\begin{array}{l}\mathrm{x} \\
\mathrm{x}\end{array}$ & $\begin{array}{l}\mathrm{x} \\
\mathrm{x}\end{array}$ & $\begin{array}{l}\mathrm{x} \\
\mathrm{x}\end{array}$ \\
\hline $\begin{array}{l}\text { Observations } \\
\text { Mean dep. var. } \\
\text { P-value }\end{array}$ & $\begin{array}{c}448,036 \\
0.179 \\
0.011\end{array}$ & $\begin{array}{c}446,152 \\
0.179 \\
0.004\end{array}$ & $\begin{array}{c}99,647 \\
0.179 \\
0.751\end{array}$ & $\begin{array}{c}346,505 \\
0.179 \\
0.188\end{array}$ \\
\hline
\end{tabular}

Notes: Other included controls: other race, mother smoked during pregnancy, mother's education (in years: $0-11,12,13-16,16+)$, mother's age $(<20,20-24,25-29,30-34,35+)$, mother married at birth, sex, birth order $(1,2,3,4+)$, multiple birth indicator, indicator for other race (non-white, non-black), indicator for child ever used public insurance, and dummy variables for child's age at end of sample in quarters; zip code level variables: population, population density, median age, average household size, pct. with less than high school $(25+)$, pct. with bachelor's degree or more $(25+)$, pct. in labor force $(16+)$, pct. of households making $<20 \mathrm{k}$, pct. of households making $>200 \mathrm{k}$, median year structure built, pct. of housing owner occupied, pct. of housing vacant, median value of owner occupied housing, pct. of families below poverty. Standard errors clustered at mother. Birth weight bins, an indicator for black, and their interaction are used in the first stage to predict whether or not the count is zero. F-statistic/P-value from a test that the coefficients on the first 4 birthweight bins interacted with black are jointly equal to zero. The omitted categories are 3000-3499 and 3000-3499* black. 
Table A.6: Asthma and Low Birthweight: Sequential Addition of Covariate Groups

\begin{tabular}{|c|c|c|c|c|c|c|c|c|}
\hline \multirow{3}{*}{ 500-999 } & \multicolumn{4}{|c|}{ Ever Diagnosed with Asthma } & \multicolumn{4}{|c|}{ No. Times Diagnosed with Asthma } \\
\hline & (1) & $(2)$ & (3) & (4) & $(5)$ & $(6)$ & $(7)$ & $(8)$ \\
\hline & $\begin{array}{c}0.154^{* * *} \\
(0.013)\end{array}$ & $\begin{array}{c}0.153 * * * \\
(0.012)\end{array}$ & $\begin{array}{c}0.153^{* * *} \\
(0.012)\end{array}$ & $\begin{array}{c}0.148^{* * * *} \\
(0.012)\end{array}$ & $\begin{array}{c}0.411^{* * * *} \\
(0.058)\end{array}$ & $\begin{array}{c}0.415^{* * *} \\
(0.057)\end{array}$ & $\begin{array}{c}0.413^{* * *} \\
(0.057)\end{array}$ & $\begin{array}{c}0.398 * * * \\
(0.057)\end{array}$ \\
\hline 1000-1499 & $\begin{array}{c}0.091^{* * * *} \\
(0.007)\end{array}$ & $\begin{array}{c}0.093^{* * *} * \\
(0.007)\end{array}$ & $\begin{array}{c}0.091^{* * *} * \\
(0.007)\end{array}$ & $\begin{array}{c}0.088^{* * *} \\
(0.007)\end{array}$ & $\begin{array}{c}0.225^{* * *} \\
(0.025)\end{array}$ & $\begin{array}{c}0.236^{* * *} \\
(0.024)\end{array}$ & $\begin{array}{c}0.232^{* * *} \\
(0.024)\end{array}$ & $\begin{array}{c}0.223^{* * *} * \\
(0.024)\end{array}$ \\
\hline 1500-1999 & $\begin{array}{c}0.051^{* * * *} \\
(0.004)\end{array}$ & $\begin{array}{c}0.059 * * * \\
(0.005)\end{array}$ & $\begin{array}{c}0.058^{* * *} \\
(0.005)\end{array}$ & $\begin{array}{c}0.056^{* * *} \\
(0.004)\end{array}$ & $\begin{array}{c}0.127^{* * * *} \\
(0.014)\end{array}$ & $\begin{array}{c}0.153^{* * *} * \\
(0.015)\end{array}$ & $\begin{array}{c}0.151^{* * * *} \\
(0.015)\end{array}$ & $\begin{array}{c}0.145^{* * * *} \\
(0.015)\end{array}$ \\
\hline 2000-2499 & $\begin{array}{c}0.020^{* * *} \\
(0.002)\end{array}$ & $\begin{array}{c}0.025^{* * *} \\
(0.002)\end{array}$ & $\begin{array}{c}0.024^{* * *} * \\
(0.002)\end{array}$ & $\begin{array}{c}0.023^{* * *} \\
(0.002)\end{array}$ & $\begin{array}{c}0.062^{* * *} \\
(0.007)\end{array}$ & $\begin{array}{c}0.077^{* * *} \\
(0.008)\end{array}$ & $\begin{array}{c}0.076^{* * *} \\
(0.008)\end{array}$ & $\begin{array}{c}0.073^{* * *} * \\
(0.008)\end{array}$ \\
\hline $2500-2999$ & $\begin{array}{c}0.008^{* * *} \\
(0.001)\end{array}$ & $\begin{array}{c}0.010^{* * *} * \\
(0.001)\end{array}$ & $\begin{array}{c}0.009 * * * \\
(0.001)\end{array}$ & $\begin{array}{c}0.009 * * * \\
(0.001)\end{array}$ & $\begin{array}{c}0.021^{* * * *} \\
(0.003)\end{array}$ & $\begin{array}{c}0.025^{* * *} \\
(0.003)\end{array}$ & $\begin{array}{c}0.024^{* * * *} \\
(0.003)\end{array}$ & $\begin{array}{c}0.024^{* * * *} \\
(0.003)\end{array}$ \\
\hline 3500-3999 & $\begin{array}{c}-0.002^{* *} * \\
(0.001)\end{array}$ & $\begin{array}{c}-0.003^{* * *} \\
(0.001)\end{array}$ & $\begin{array}{c}-0.003^{* * *} \\
(0.001)\end{array}$ & $\begin{array}{c}-0.003^{* * * *} \\
(0.001)\end{array}$ & $\begin{array}{l}-0.003 \\
(0.003)\end{array}$ & $\begin{array}{c}-0.004 \\
(0.003)\end{array}$ & $\begin{array}{l}-0.004 \\
(0.003)\end{array}$ & $\begin{array}{c}-0.004 \\
(0.003)\end{array}$ \\
\hline $4000-4499$ & $\begin{array}{c}-0.006^{* * *} \\
(0.002)\end{array}$ & $\begin{array}{c}-0.008^{* * *} \\
(0.002)\end{array}$ & $\begin{array}{c}-0.008^{* * *} \\
(0.002)\end{array}$ & $\begin{array}{c}-0.007^{* * *} \\
(0.002)\end{array}$ & $\begin{array}{c}-0.013^{* * *} * \\
(0.004)\end{array}$ & $\begin{array}{c}-0.016^{* * *} \\
(0.004)\end{array}$ & $\begin{array}{c}-0.016^{* * *} \\
(0.004)\end{array}$ & $\begin{array}{c}-0.014^{* * * *} \\
(0.004)\end{array}$ \\
\hline $4500-4999$ & $\begin{array}{l}-0.002 \\
(0.004)\end{array}$ & $\begin{array}{l}-0.006 \\
(0.004)\end{array}$ & $\begin{array}{c}-0.005 \\
(0.004)\end{array}$ & $\begin{array}{l}-0.005 \\
(0.004)\end{array}$ & $\begin{array}{l}-0.013 \\
(0.010)\end{array}$ & $\begin{array}{c}-0.020^{* *} \\
(0.010)\end{array}$ & $\begin{array}{c}-0.019^{* *} \\
(0.010)\end{array}$ & $\begin{array}{c}-0.018^{*} \\
(0.010)\end{array}$ \\
\hline Black & $\begin{array}{c}0.091^{* * *} * \\
(0.002)\end{array}$ & $\begin{array}{c}0.056^{* * *} * \\
(0.002)\end{array}$ & $\begin{array}{c}0.046^{* * *} * \\
(0.002)\end{array}$ & $\begin{array}{c}0.045^{* * * *} \\
(0.002)\end{array}$ & $\begin{array}{c}0.250^{* * * *} \\
(0.007)\end{array}$ & $\begin{array}{c}0.153^{* * *} * \\
(0.007)\end{array}$ & $\begin{array}{c}0.122^{* * *} \\
(0.008)\end{array}$ & $\begin{array}{c}0.113^{* * * *} \\
(0.008)\end{array}$ \\
\hline $500-999 *$ black & $\begin{array}{c}0.086^{* * *} \\
(0.022)\end{array}$ & $\begin{array}{c}0.092^{* * *} \\
(0.021)\end{array}$ & $\begin{array}{c}0.092^{* * *} \\
(0.021)\end{array}$ & $\begin{array}{c}0.096^{* * *} \\
(0.021)\end{array}$ & $\begin{array}{c}0.471^{* * *} \\
(0.107)\end{array}$ & $\begin{array}{c}0.482^{* * *} \\
(0.106)\end{array}$ & $\begin{array}{c}0.483^{* * *} \\
(0.106)\end{array}$ & $\begin{array}{c}0.489^{* * *} \\
(0.106)\end{array}$ \\
\hline 1000-1499* black & $\begin{array}{c}0.057^{* * * *} \\
(0.016)\end{array}$ & $\begin{array}{c}0.054^{* * *} * \\
(0.016)\end{array}$ & $\begin{array}{c}0.053^{* * *} * \\
(0.016)\end{array}$ & $\begin{array}{c}0.054^{* * * *} \\
(0.016)\end{array}$ & $\begin{array}{c}0.309 * * * \\
(0.069)\end{array}$ & $\begin{array}{c}0.295^{* * * *} \\
(0.069)\end{array}$ & $\begin{array}{c}0.281^{* * * *} \\
(0.067)\end{array}$ & $\begin{array}{c}0.277^{* * * *} \\
(0.067)\end{array}$ \\
\hline $1500-1999 *$ black & $\begin{array}{c}0.036^{* * *} * \\
(0.011)\end{array}$ & $\begin{array}{l}0.028^{* *} \\
(0.011)\end{array}$ & $\begin{array}{c}0.029^{* * *} * \\
(0.011)\end{array}$ & $\begin{array}{c}0.028^{* * *} * \\
(0.011)\end{array}$ & $\begin{array}{c}0.253^{* * *} * \\
(0.053)\end{array}$ & $\begin{array}{c}0.228^{* * *} * \\
(0.053)\end{array}$ & $\begin{array}{c}0.228^{* * *} * \\
(0.053)\end{array}$ & $\begin{array}{c}0.222^{* * *} * \\
(0.052)\end{array}$ \\
\hline $2000-2499 *$ black & $\begin{array}{c}0.024^{* * *} \\
(0.006)\end{array}$ & $\begin{array}{c}0.019 * * * \\
(0.006)\end{array}$ & $\begin{array}{c}0.019 * * * \\
(0.006)\end{array}$ & $\begin{array}{c}0.018^{* * *} * \\
(0.006)\end{array}$ & $\begin{array}{c}0.112^{* * *} * \\
(0.027)\end{array}$ & $\begin{array}{c}0.096^{* * *} * \\
(0.026)\end{array}$ & $\begin{array}{c}0.093^{* * *} \\
(0.026)\end{array}$ & $\begin{array}{c}0.089^{* * *} \\
(0.026)\end{array}$ \\
\hline $2500-2999 *$ black & $\begin{array}{l}0.008^{* *} \\
(0.004)\end{array}$ & $\begin{array}{c}0.005 \\
(0.004)\end{array}$ & $\begin{array}{c}0.005 \\
(0.004)\end{array}$ & $\begin{array}{c}0.004 \\
(0.004)\end{array}$ & $\begin{array}{c}0.045^{* * * *} \\
(0.014)\end{array}$ & $\begin{array}{c}0.037^{* * *} * \\
(0.014)\end{array}$ & $\begin{array}{c}0.035^{* *} \\
(0.013)\end{array}$ & $\begin{array}{c}0.029^{* *} \\
(0.013)\end{array}$ \\
\hline $3500-3999 *$ black & $\begin{array}{c}-0.008^{* *} \\
(0.004)\end{array}$ & $\begin{array}{l}-0.005 \\
(0.004)\end{array}$ & $\begin{array}{l}-0.005 \\
(0.004)\end{array}$ & $\begin{array}{l}-0.004 \\
(0.003)\end{array}$ & $\begin{array}{l}-0.013 \\
(0.013)\end{array}$ & $\begin{array}{l}-0.005 \\
(0.013)\end{array}$ & $\begin{array}{l}-0.003 \\
(0.013)\end{array}$ & $\begin{array}{l}-0.001 \\
(0.013)\end{array}$ \\
\hline $4000-4499 *$ black & $\begin{array}{l}-0.007 \\
(0.006)\end{array}$ & $\begin{array}{l}-0.001 \\
(0.006)\end{array}$ & $\begin{array}{l}-0.001 \\
(0.006)\end{array}$ & $\begin{array}{l}-0.001 \\
(0.006)\end{array}$ & $\begin{array}{l}-0.001 \\
(0.024)\end{array}$ & $\begin{array}{c}0.017 \\
(0.024)\end{array}$ & $\begin{array}{c}0.019 \\
(0.024)\end{array}$ & $\begin{array}{c}0.021 \\
(0.024)\end{array}$ \\
\hline $4500-4999 *$ black & $\begin{array}{c}-0.035^{* *} \\
(0.016)\end{array}$ & $\begin{array}{c}-0.029^{*} \\
(0.016)\end{array}$ & $\begin{array}{c}-0.028^{*} \\
(0.016)\end{array}$ & $\begin{array}{c}-0.027^{*} \\
(0.016)\end{array}$ & $\begin{array}{c}-0.099^{* *} \\
(0.047)\end{array}$ & $\begin{array}{c}-0.079^{*} \\
(0.046)\end{array}$ & $\begin{array}{c}-0.078^{*} \\
(0.046)\end{array}$ & $\begin{array}{c}-0.074 \\
(0.046)\end{array}$ \\
\hline Individual vars & - & $\mathrm{x}$ & $\mathrm{x}$ & $\mathrm{x}$ & - & $\mathrm{x}$ & $\mathrm{x}$ & $\mathrm{x}$ \\
\hline Census vars & - & - & $\mathrm{x}$ & $\mathrm{x}$ & - & - & $\mathrm{x}$ & $\mathrm{x}$ \\
\hline Hospital fixed effects & - & - & - & $\mathrm{x}$ & - & - & - & $\mathrm{x}$ \\
\hline Observations & 448,036 & 447,251 & 446,152 & 446,152 & 448,036 & 447,251 & 446,152 & 446,152 \\
\hline R-sq & 0.026 & 0.055 & 0.058 & 0.066 & 0.024 & 0.045 & 0.047 & 0.056 \\
\hline Mean dep. var. & 0.084 & 0.084 & 0.084 & 0.084 & 0.179 & 0.179 & 0.179 & 0.179 \\
\hline Clusters & 369,797 & 369,214 & 368,295 & 368,295 & 369,797 & 369,214 & 368,295 & 368,295 \\
\hline F-statistic & 11.958 & 10.204 & 10.392 & 10.714 & 18.506 & 16.399 & 16.005 & 15.718 \\
\hline $\mathrm{P}$-value & 0.000 & 0.000 & 0.000 & 0.000 & 0.000 & 0.000 & 0.000 & 0.000 \\
\hline
\end{tabular}

Notes: All regressions include dummy variables for child's age at end of sample in quarters. Other included controls: other race, mother smoked during pregnancy, mother's education (in years: 0-11, 12, 13-16, 16+), mother's age $(<20,20-24,25-29$, 30-34, 35+), mother married at birth, sex, birth order $(1,2,3,4+)$, multiple birth indicator, indicator for other race (nonwhite, non-black), and indicator for child ever used public insurance; zip code level variables: population, population density, median age, average household size, pct. with less than high school $(25+)$, pct. with bachelor's degree or more $(25+)$, pct. in labor force $(16+)$, pct. of households making $<20 \mathrm{k}$, pct. of households making $>200 \mathrm{k}$, median year structure built, pct. of housing owner occupied, pct. of housing vacant, median value of owner occupied housing, pct. of families below poverty. F-statistic/P-value from a test that the coefficients on the first 4 birthweight bins interacted with black are jointly equal to zero. Standard errors clustered at mother. The omitted categories are 3000-3499 and 3000-3499* black. 
Table A.7: Asthma and Low Birthweight: Zip Code Fixed Effects

\begin{tabular}{|c|c|c|}
\hline & $\begin{array}{c}\text { Ever Diagnosed with Asthma } \\
(1)\end{array}$ & No. Times Diagnosed with Asthma \\
\hline $500-999$ & $\begin{array}{c}0.148^{* * *} \\
(0.012)\end{array}$ & $\begin{array}{c}0.402^{* * *} \\
(0.057)\end{array}$ \\
\hline 1000-1499 & $\begin{array}{c}0.088^{* * *} * \\
(0.007)\end{array}$ & $\begin{array}{c}0.224^{* * * *} \\
(0.024)\end{array}$ \\
\hline 1500-1999 & $\begin{array}{c}0.056^{* * *} \\
(0.004)\end{array}$ & $\begin{array}{c}0.146^{* * *} \\
(0.015)\end{array}$ \\
\hline 2000-2499 & $\begin{array}{c}0.023^{* * *} * \\
(0.002)\end{array}$ & $\begin{array}{c}0.073^{* * *} * \\
(0.008)\end{array}$ \\
\hline 2500-2999 & $\begin{array}{c}0.009^{* * *} * \\
(0.001)\end{array}$ & $\begin{array}{c}0.024^{* * * *} \\
(0.003)\end{array}$ \\
\hline 3500-3999 & $\begin{array}{c}-0.003^{* * *} \\
(0.001)\end{array}$ & $\begin{array}{l}-0.003 \\
(0.003)\end{array}$ \\
\hline 4000-4499 & $\begin{array}{c}-0.007^{* * *} * \\
(0.002)\end{array}$ & $\begin{array}{c}-0.014^{* * *} \\
(0.004)\end{array}$ \\
\hline 4500-4999 & $\begin{array}{l}-0.005 \\
(0.004)\end{array}$ & $\begin{array}{l}-0.018^{*} \\
(0.010)\end{array}$ \\
\hline Black & $\begin{array}{c}0.040^{* * *} \\
(0.002)\end{array}$ & $\begin{array}{c}0.103^{* * *} \\
(0.008)\end{array}$ \\
\hline 500-999* black & $\begin{array}{c}0.095^{* * *} * \\
(0.021)\end{array}$ & $\begin{array}{c}0.484^{* * * *} \\
(0.106)\end{array}$ \\
\hline 1000-1499* black & $\begin{array}{c}0.053^{* * *} * \\
(0.016)\end{array}$ & $\begin{array}{c}0.275^{* * *} * \\
(0.067)\end{array}$ \\
\hline 1500-1999* black & $\begin{array}{c}0.029^{* * *} * \\
(0.011)\end{array}$ & $\begin{array}{c}0.222^{* * *} \\
(0.052)\end{array}$ \\
\hline 2000-2499* black & $\begin{array}{c}0.018^{* * *} \\
(0.006)\end{array}$ & $\begin{array}{c}0.087^{* * *} * \\
(0.026)\end{array}$ \\
\hline $2500-2999 *$ black & $\begin{array}{c}0.004 \\
(0.004)\end{array}$ & $\begin{array}{c}0.029^{* *} \\
(0.013)\end{array}$ \\
\hline 3500-3999* black & $\begin{array}{l}-0.004 \\
(0.003)\end{array}$ & $\begin{array}{l}-0.001 \\
(0.013)\end{array}$ \\
\hline 4000-4499* black & $\begin{array}{l}-0.001 \\
(0.006)\end{array}$ & $\begin{array}{c}0.023 \\
(0.024)\end{array}$ \\
\hline $4500-4999 *$ black & $\begin{array}{l}-0.026 \\
(0.016)\end{array}$ & $\begin{array}{l}-0.069 \\
(0.046)\end{array}$ \\
\hline Individual/census vars & $\mathrm{x}$ & $\mathrm{x}$ \\
\hline Hospital fixed effects & $\mathrm{x}$ & $\mathrm{x}$ \\
\hline Zip code fixed effects & $\mathrm{x}$ & $\mathrm{x}$ \\
\hline $\begin{array}{l}\text { Observations } \\
\text { R-squared } \\
\text { Mean dep. var. } \\
\text { Clusters } \\
\text { F-statistic } \\
\text { P-value }\end{array}$ & $\begin{array}{c}446,152 \\
0.070 \\
0.084 \\
368,295 \\
10.546 \\
0.000\end{array}$ & $\begin{array}{c}446,152 \\
0.060 \\
0.179 \\
368,295 \\
15.410 \\
0.000\end{array}$ \\
\hline
\end{tabular}

Notes: All regressions include dummy variables for child's age at end of sample in quarters. Other included controls: other race, mother smoked during pregnancy, mother's education (in years: 0$11,12,13-16,16+)$, mother's age $(<20,20-24,25-29,30-34,35+)$, mother married at birth, sex, birth order $(1,2,3,4+)$, multiple birth indicator, indicator for other race (non-white, non-black), and indicator for child ever used public insurance; zip code level variables: population, population density, median age, average household size, pct. with less than high school $(25+)$, pct. with bachelor's degree or more $(25+)$, pct. in labor force $(16+)$, pct. of households making $<20 \mathrm{k}$, pct. of households making $>200 \mathrm{k}$, median year structure built, pct. of housing owner occupied, pct. of housing vacant, median value of owner occupied housing, pct. of families below poverty. Fstatistic/P-value from a test that the coefficients on the first 4 birthweight bins interacted with black are jointly equal to zero. Standard errors clustered at mother. The omitted categories are 3000-3499 and 3000-3499* black. 
Table A.8: Asthma and Low Birthweight: Reporting Coefficients on Census Variables

\begin{tabular}{|c|c|c|c|c|}
\hline & \multicolumn{2}{|c|}{$\begin{array}{l}\text { Ever Diagnosed with Asthma } \\
\text { (1) }\end{array}$} & \multicolumn{2}{|c|}{$\begin{array}{l}\text { No. Times Diagnosed with Asthma } \\
\text { (3) }\end{array}$} \\
\hline $500-999$ & $\begin{array}{c}0.148^{* * *} \\
(0.012)\end{array}$ & $\begin{array}{c}0.127^{* * *} \\
(0.029)\end{array}$ & $\begin{array}{c}0.398^{* * *} \\
(0.057)\end{array}$ & $\begin{array}{c}0.599 * * * \\
(0.179)\end{array}$ \\
\hline 1000-1499 & $\begin{array}{c}0.088^{* * *} \\
(0.007)\end{array}$ & $\begin{array}{c}0.078^{* * *} \\
(0.014)\end{array}$ & $\begin{array}{c}0.223^{* * *} \\
(0.024)\end{array}$ & $0.240^{* * *}$ \\
\hline 1500-1999 & $\begin{array}{c}0.056^{* * *} \\
(0.004)\end{array}$ & $\begin{array}{c}0.043^{* * *} \\
(0.009)\end{array}$ & $\begin{array}{c}0.145^{* * *} \\
(0.015)\end{array}$ & $\begin{array}{c}0.133^{* * * *} \\
(0.028)\end{array}$ \\
\hline $2000-2499$ & $\begin{array}{c}0.023^{* * *} * \\
(0.002)\end{array}$ & $\begin{array}{c}0.014^{* * *} \\
(0.005)\end{array}$ & $\begin{array}{c}0.073^{* * *} \\
(0.008)\end{array}$ & $\begin{array}{c}0.052^{* * * *} \\
(0.015)\end{array}$ \\
\hline 2500-2999 & $\begin{array}{c}0.009^{* * *} \\
(0.001)\end{array}$ & $\begin{array}{c}0.009 * * * \\
(0.003)\end{array}$ & $\begin{array}{c}0.024 * * * \\
(0.003)\end{array}$ & $\begin{array}{c}0.027 * * * \\
(0.008)\end{array}$ \\
\hline 3500-3999 & $\begin{array}{c}-0.003^{* * *} \\
(0.001)\end{array}$ & $\begin{array}{l}-0.000 \\
(0.002)\end{array}$ & $\begin{array}{l}-0.004 \\
(0.003)\end{array}$ & $\begin{array}{l}-0.001 \\
(0.006)\end{array}$ \\
\hline $4000-4499$ & $\begin{array}{c}-0.007^{* * *} \\
(0.002)\end{array}$ & $\begin{array}{l}-0.005 \\
(0.004)\end{array}$ & $\begin{array}{c}-0.014^{* * *} \\
(0.004)\end{array}$ & $\begin{array}{l}-0.007 \\
(0.009)\end{array}$ \\
\hline $4500-4999$ & $\begin{array}{l}-0.005 \\
(0.004)\end{array}$ & $\begin{array}{l}-0.008 \\
(0.010)\end{array}$ & $\begin{array}{c}-0.018^{*} \\
(0.010)\end{array}$ & $\begin{array}{l}-0.026 \\
(0.023)\end{array}$ \\
\hline Black & $\begin{array}{c}0.045^{* * *} \\
(0.002)\end{array}$ & $\begin{array}{c}0.000 \\
(.)\end{array}$ & $\begin{array}{c}0.113^{* * *} \\
(0.008)\end{array}$ & $\begin{array}{l}0.000 \\
(.)\end{array}$ \\
\hline $500-999 *$ black & $\begin{array}{c}0.096^{* * *} \\
(0.021)\end{array}$ & $\begin{array}{l}0.091^{*} \\
(0.049)\end{array}$ & $\begin{array}{c}0.489^{* * *} \\
(0.106)\end{array}$ & $\begin{array}{c}0.419 \\
(0.267)\end{array}$ \\
\hline 1000-1499* black & $\begin{array}{c}0.054^{* * *} \\
(0.016)\end{array}$ & $\begin{array}{c}0.035 \\
(0.036)\end{array}$ & $\begin{array}{c}0.277^{* * *} * \\
(0.067)\end{array}$ & $\begin{array}{c}0.234 \\
(0.157)\end{array}$ \\
\hline 1500-1999* black & $\begin{array}{c}0.028^{* * * *} \\
(0.011)\end{array}$ & $\begin{array}{c}0.047^{* *} \\
(0.024)\end{array}$ & $\begin{array}{c}0.222^{* * *} * \\
(0.052)\end{array}$ & $\begin{array}{c}0.319^{* * *} \\
(0.119)\end{array}$ \\
\hline 2000-2499* black & $\begin{array}{c}0.018^{* * *} \\
(0.006)\end{array}$ & $\begin{array}{c}0.031^{* *} \\
(0.015)\end{array}$ & $\begin{array}{c}0.089 * * * \\
(0.026)\end{array}$ & $\begin{array}{l}0.106^{*} \\
(0.058)\end{array}$ \\
\hline $2500-2999 *$ black & $\begin{array}{c}0.004 \\
(0.004)\end{array}$ & $\begin{array}{l}-0.001 \\
(0.009)\end{array}$ & $\begin{array}{c}0.029^{* *} \\
(0.013)\end{array}$ & $\begin{array}{l}-0.002 \\
(0.031)\end{array}$ \\
\hline $3500-3999 *$ black & $\begin{array}{c}-0.004 \\
(0.003)\end{array}$ & $\begin{array}{c}0.005 \\
(0.009)\end{array}$ & $\begin{array}{l}-0.001 \\
(0.013)\end{array}$ & $\begin{array}{c}0.015 \\
(0.031)\end{array}$ \\
\hline $4000-4499 *$ black & $\begin{array}{l}-0.001 \\
(0.006)\end{array}$ & $\begin{array}{c}0.004 \\
(0.017)\end{array}$ & $\begin{array}{c}0.021 \\
(0.024)\end{array}$ & $\begin{array}{c}0.043 \\
(0.054)\end{array}$ \\
\hline $4500-4999 *$ black & $\begin{array}{c}-0.027^{*} \\
(0.016)\end{array}$ & $\begin{array}{c}0.017 \\
(0.045)\end{array}$ & $\begin{array}{c}-0.074 \\
(0.046)\end{array}$ & $\begin{array}{c}0.033 \\
(0.096)\end{array}$ \\
\hline Population density & $0.000^{* * *}$ & $\begin{array}{c}0.000 \\
0.000)\end{array}$ & $0.000^{*}$ & $0.000^{*}$ \\
\hline Median age & $\begin{array}{c}0.001^{* * *} * \\
(0.000)\end{array}$ & $\begin{array}{l}-0.001 \\
(0.001)\end{array}$ & $\begin{array}{l}0.001^{*} \\
(0.001)\end{array}$ & $\begin{array}{c}0.001 \\
(0.003)\end{array}$ \\
\hline Avg. household size & $\begin{array}{c}-0.007^{* *} \\
(0.003)\end{array}$ & $\begin{array}{c}-0.016 \\
(0.014)\end{array}$ & $\begin{array}{c}-0.027^{* * *} \\
(0.009)\end{array}$ & $\begin{array}{c}0.045 \\
(0.047)\end{array}$ \\
\hline Pct. < high school & $\begin{array}{l}0.000^{* *} \\
(0.000)\end{array}$ & $\begin{array}{l}-0.000 \\
(0.001)\end{array}$ & $\begin{array}{l}-0.001 \\
(0.000)\end{array}$ & $\begin{array}{l}-0.002 \\
(0.002)\end{array}$ \\
\hline Pct. college + & $\begin{array}{c}-0.000^{* * *} \\
(0.000)\end{array}$ & $\begin{array}{c}-0.001^{* * * *} \\
(0.000)\end{array}$ & $\begin{array}{c}-0.000^{* *} \\
(0.000)\end{array}$ & $\begin{array}{l}-0.002 \\
(0.001)\end{array}$ \\
\hline Pct. in labor force & $\begin{array}{c}0.001^{* * *} \\
(0.000)\end{array}$ & $\begin{array}{l}-0.000 \\
(0.001)\end{array}$ & $\begin{array}{c}0.003^{* * *} * \\
(0.000)\end{array}$ & $\begin{array}{l}-0.002 \\
(0.002)\end{array}$ \\
\hline Pct. households $<\$ 20 \mathrm{k}$ & $\begin{array}{c}0.002^{* * *} \\
(0.000)\end{array}$ & $\begin{array}{l}-0.000 \\
(0.001)\end{array}$ & $\begin{array}{c}0.006^{* * *} * \\
(0.001)\end{array}$ & $\begin{array}{l}-0.004 \\
(0.004)\end{array}$ \\
\hline Pct. households $>\$ 200 \mathrm{k}$ & $\begin{array}{c}0.001^{* * *} \\
(0.000)\end{array}$ & $\begin{array}{c}0.002^{* *} \\
(0.001)\end{array}$ & $\begin{array}{c}0.003^{* * *} \\
(0.001)\end{array}$ & $\begin{array}{c}0.004 \\
(0.003)\end{array}$ \\
\hline Median year structure built & $\begin{array}{l}0.000^{*} \\
(0.000)\end{array}$ & $\begin{array}{c}0.000 \\
(0.000)\end{array}$ & $\begin{array}{c}0.000^{* * *} \\
(0.000)\end{array}$ & $\begin{array}{c}0.001 \\
(0.001)\end{array}$ \\
\hline Pct. owner occupied & $\begin{array}{l}0.000^{*} \\
(0.000)\end{array}$ & $\begin{array}{c}0.000 \\
(0.000)\end{array}$ & $\begin{array}{l}0.000^{*} \\
(0.000)\end{array}$ & $\begin{array}{l}-0.001 \\
(0.001)\end{array}$ \\
\hline Pct. vacant & $\begin{array}{c}-0.000^{* *} \\
(0.000)\end{array}$ & $\begin{array}{l}-0.000 \\
(0.000)\end{array}$ & $\begin{array}{l}-0.000 \\
(0.000)\end{array}$ & $\begin{array}{c}0.003 \\
(0.002)\end{array}$ \\
\hline Median value (owner occ.) & $\begin{array}{c}-0.000^{* * * *} \\
(0.000)\end{array}$ & $\begin{array}{l}-0.000 \\
(0.000)\end{array}$ & $\begin{array}{c}-0.000^{* *} \\
(0.000)\end{array}$ & $\begin{array}{l}-0.000 \\
(0.000)\end{array}$ \\
\hline Pct. below poverty & $\begin{array}{c}-0.001^{* * *} * \\
(0.000)\end{array}$ & $\begin{array}{c}0.000 \\
(0.001)\end{array}$ & $\begin{array}{c}0.000 \\
(0.001)\end{array}$ & $\begin{array}{c}0.001 \\
(0.004)\end{array}$ \\
\hline Avg. commute & $\begin{array}{l}0.000 \\
(0.000)\end{array}$ & $\begin{array}{l}-0.001 \\
(0.001)\end{array}$ & $\begin{array}{l}-0.000 \\
(0.000)\end{array}$ & $\begin{array}{l}-0.001 \\
(0.002)\end{array}$ \\
\hline Total population & $\begin{array}{l}-0.000^{* * * *} \\
(0.000)\end{array}$ & $\begin{array}{c}-0.000^{* *} \\
(0.000)\end{array}$ & $\begin{array}{c}-0.000^{* * *} \\
(0.000)\end{array}$ & $\begin{array}{l}-0.000 \\
(0.000)\end{array}$ \\
\hline $\begin{array}{l}\text { Individual/census vars \& hospital fixed effects } \\
\text { Mother fixed effects }\end{array}$ & $\begin{array}{l}x \\
-\end{array}$ & $\mathrm{x}$ & $\mathrm{x}$ & $\begin{array}{l}x \\
x\end{array}$ \\
\hline $\begin{array}{l}\text { Observations } \\
\text { R-squared } \\
\text { Mean dep. var. } \\
\text { Clusters } \\
\text { F-statistic } \\
\text { P-value }\end{array}$ & $\begin{array}{c}446,152 \\
0.066 \\
0.084 \\
368,295 \\
10.714 \\
0.000\end{array}$ & $\begin{array}{c}446,152 \\
0.023 \\
0.084 \\
368,295 \\
2.282 \\
0.058\end{array}$ & $\begin{array}{c}446,152 \\
0.056 \\
0.179 \\
368,295 \\
15.718 \\
0.000\end{array}$ & $\begin{array}{c}446,152 \\
0.022 \\
0.179 \\
368,295 \\
2.515 \\
0.039\end{array}$ \\
\hline
\end{tabular}

Notes: All regressions include dummy variables for child's age at end of sample in quarters. Other included controls: other race, mother smoked during pregnancy, mother's education (in years: 0-11, 12, 13-16, 16+), mother's age $(<20,20-24,25-29,30-34,35+$ ), mother married at birth, sex, birth order $(1,2,3,4+)$, multiple birth indicator, indicator for other race (non-white, non-black), and indicator for child ever used public insurance. F-statistic/P-value from a test that the coefficients on the first 4 birthweight bins interacted with black are jointly equal to zero. Standard ferors clustered at mother. The omitted categories are 3000-3499 and $3000-3499 *$ black. 
Table A.9: Asthma and Low Birthweight: Only Nonhispanic Black and White Children

\begin{tabular}{|c|c|c|c|c|c|c|}
\hline & \multicolumn{3}{|c|}{ Ever Diagnosed with Asthma } & \multicolumn{3}{|c|}{ No. Times Diagnosed with Asthma } \\
\hline $500-999$ & $\begin{array}{c}0.112^{* * * *} \\
(0.015)\end{array}$ & $\begin{array}{c}0.108^{* * *} \\
(0.015)\end{array}$ & $\begin{array}{c}0.083 * * \\
(0.034)\end{array}$ & $\begin{array}{c}0.230^{* * *} \\
(0.046)\end{array}$ & $\begin{array}{c}0.227^{* * *} \\
(0.046)\end{array}$ & $\begin{array}{c}0.253^{* *} \\
(0.125)\end{array}$ \\
\hline 1000-1499 & $\begin{array}{c}0.067^{* * * *} \\
(0.009)\end{array}$ & $\begin{array}{c}0.066^{* * *} * \\
(0.009)\end{array}$ & $\begin{array}{c}0.062^{* * * *} \\
(0.016)\end{array}$ & $\begin{array}{c}0.147^{* * *} * \\
(0.025)\end{array}$ & $\begin{array}{c}0.151^{* * *} * \\
(0.025)\end{array}$ & $\begin{array}{c}0.155^{* * *} * \\
(0.045)\end{array}$ \\
\hline 1500-1999 & $\begin{array}{c}0.042^{* * *} \\
(0.005)\end{array}$ & $\begin{array}{c}0.045 * * * \\
(0.005)\end{array}$ & $\begin{array}{c}0.023^{* *} \\
(0.010)\end{array}$ & $\begin{array}{c}0.079 * * * \\
(0.013)\end{array}$ & $\begin{array}{c}0.095^{* * *} \\
(0.014)\end{array}$ & $\begin{array}{c}0.060 * * \\
(0.026)\end{array}$ \\
\hline $2000-2499$ & $\begin{array}{c}0.022^{* * * *} \\
(0.003)\end{array}$ & $\begin{array}{c}0.023^{* * * *} \\
(0.003)\end{array}$ & $\begin{array}{c}0.019^{* * * *} \\
(0.006)\end{array}$ & $\begin{array}{c}0.049^{* * *} \\
(0.008)\end{array}$ & $\begin{array}{c}0.056^{* * *} \\
(0.008)\end{array}$ & $\begin{array}{c}0.055 * * * \\
(0.015)\end{array}$ \\
\hline $2500-2999$ & $\begin{array}{c}0.007 * * * \\
(0.001)\end{array}$ & $\begin{array}{c}0.007^{* * *} * \\
(0.001)\end{array}$ & $\begin{array}{c}0.007 * * \\
(0.003)\end{array}$ & $\begin{array}{c}0.016^{* * *} \\
(0.004)\end{array}$ & $\begin{array}{c}0.016^{* * *} * \\
(0.004)\end{array}$ & $0.015^{*}$ \\
\hline 3500-3999 & $\begin{array}{c}-0.002^{*} \\
(0.001)\end{array}$ & $\begin{array}{c}-0.003 * * * \\
(0.001)\end{array}$ & $\begin{array}{c}0.001 \\
(0.002)\end{array}$ & $\begin{array}{l}-0.002 \\
(0.003)\end{array}$ & $\begin{array}{c}-0.005^{*} \\
(0.003)\end{array}$ & $\begin{array}{l}-0.009 \\
(0.005)\end{array}$ \\
\hline 4000-4499 & $\begin{array}{l}-0.003^{*} \\
(0.002)\end{array}$ & $\begin{array}{c}-0.006 * * * \\
(0.002)\end{array}$ & $\begin{array}{l}-0.006^{*} \\
(0.004)\end{array}$ & $\begin{array}{l}-0.007^{*} \\
(0.004)\end{array}$ & $\begin{array}{c}-0.013^{* * *} * \\
(0.004)\end{array}$ & $\begin{array}{c}-0.018^{* *} \\
(0.009)\end{array}$ \\
\hline $4500-4999$ & $\begin{array}{c}0.003 \\
(0.005)\end{array}$ & $\begin{array}{l}-0.002 \\
(0.005)\end{array}$ & $\begin{array}{l}-0.001 \\
(0.010)\end{array}$ & $\begin{array}{c}0.001 \\
(0.010)\end{array}$ & $\begin{array}{l}-0.010 \\
(0.010)\end{array}$ & $\begin{array}{l}-0.022 \\
(0.022)\end{array}$ \\
\hline Black & $\begin{array}{c}0.108^{* * *} * \\
(0.002)\end{array}$ & $\begin{array}{c}0.052^{* * *} * \\
(0.003)\end{array}$ & $\begin{array}{c}0.000 \\
(.)\end{array}$ & $\begin{array}{c}0.300^{* * *} * \\
(0.008)\end{array}$ & $\begin{array}{c}0.126^{* * *} \\
(0.009)\end{array}$ & 0.000 \\
\hline $500-999 *$ black & $\begin{array}{c}0.118^{* * *} \\
(0.024)\end{array}$ & $\begin{array}{c}0.125 * * * \\
(0.024)\end{array}$ & $\begin{array}{l}0.129 * * \\
(0.054)\end{array}$ & $\begin{array}{c}0.609 * * * \\
(0.104)\end{array}$ & $\begin{array}{c}0.618^{* * *} \\
(0.103)\end{array}$ & $\begin{array}{c}0.786^{* * * *} \\
(0.252)\end{array}$ \\
\hline $1000-1499 *$ black & $\begin{array}{c}0.083^{* * *} * \\
(0.017)\end{array}$ & $\begin{array}{c}0.077^{* * *} * \\
(0.017)\end{array}$ & $\begin{array}{c}0.045 \\
(0.039)\end{array}$ & $\begin{array}{c}0.379^{* * *} * \\
(0.071)\end{array}$ & $\begin{array}{c}0.349^{* * *} \\
(0.070)\end{array}$ & $\begin{array}{l}0.334^{*} \\
(0.172)\end{array}$ \\
\hline 1500-1999* black & $\begin{array}{c}0.045^{* * *} * \\
(0.012)\end{array}$ & $\begin{array}{c}0.038 * * * \\
(0.012)\end{array}$ & $\begin{array}{l}0.052^{* *} * \\
(0.026)\end{array}$ & $\begin{array}{c}0.314^{* * *} \\
(0.057)\end{array}$ & $\begin{array}{c}0.281^{* * *} \\
(0.057)\end{array}$ & $\begin{array}{c}0.401^{* * * *} \\
(0.134)\end{array}$ \\
\hline 2000-2499* black & $\begin{array}{c}0.018^{* * * *} \\
(0.007)\end{array}$ & $\begin{array}{c}0.014^{* *} \\
(0.007)\end{array}$ & $\begin{array}{c}0.023 \\
(0.016)\end{array}$ & $\begin{array}{c}0.112^{* * * *} \\
(0.029)\end{array}$ & $\begin{array}{c}0.093^{* * *} * \\
(0.028)\end{array}$ & $\begin{array}{c}0.093 \\
(0.064)\end{array}$ \\
\hline $2500-2999 *$ black & $\begin{array}{c}0.010^{* *} \\
(0.004)\end{array}$ & $\begin{array}{c}0.006 \\
(0.004)\end{array}$ & $\begin{array}{l}-0.006 \\
(0.010)\end{array}$ & $\begin{array}{c}0.047^{* * *} * \\
(0.015)\end{array}$ & $0.031^{* *}$ & $\begin{array}{l}-0.014 \\
(0.035)\end{array}$ \\
\hline $3500-3999 *$ black & $\begin{array}{c}-0.009^{* *} * \\
(0.004)\end{array}$ & $\begin{array}{l}-0.005 \\
(0.004)\end{array}$ & $\begin{array}{l}-0.003 \\
(0.010)\end{array}$ & $\begin{array}{l}-0.011 \\
(0.015)\end{array}$ & $\begin{array}{l}0.003 \\
(0.015)\end{array}$ & $\begin{array}{c}0.019 \\
(0.037)\end{array}$ \\
\hline $4000-4499 *$ black & $\begin{array}{c}-0.013^{*} \\
(0.007)\end{array}$ & $\begin{array}{l}-0.003 \\
(0.007)\end{array}$ & $\begin{array}{c}0.008 \\
(0.019)\end{array}$ & $\begin{array}{l}-0.016 \\
(0.027)\end{array}$ & $\begin{array}{c}0.018 \\
(0.027)\end{array}$ & $\begin{array}{c}0.077 \\
(0.064)\end{array}$ \\
\hline $4500-4999 *$ black & $\begin{array}{c}-0.039 * * \\
(0.018)\end{array}$ & $\begin{array}{l}-0.028 \\
(0.018)\end{array}$ & $\begin{array}{c}0.014 \\
(0.053)\end{array}$ & $\begin{array}{c}-0.123^{* *} \\
(0.052)\end{array}$ & $\begin{array}{c}-0.089^{*} \\
(0.050)\end{array}$ & $\begin{array}{c}0.016 \\
(0.116)\end{array}$ \\
\hline $\begin{array}{l}\text { Individual/census vars } \\
\text { Hospital fixed effects }\end{array}$ & $\begin{array}{l}- \\
-\end{array}$ & $\begin{array}{l}\mathrm{x} \\
\mathrm{x}\end{array}$ & $\begin{array}{l}\mathrm{x} \\
\mathrm{x}\end{array}$ & $\begin{array}{l}- \\
-\end{array}$ & $\begin{array}{l}\mathrm{x} \\
\mathrm{x}\end{array}$ & $\begin{array}{l}\mathrm{x} \\
\mathrm{x}\end{array}$ \\
\hline $\begin{array}{l}\text { Observations } \\
\text { R-squared } \\
\text { Mean dep. var. } \\
\text { Clusters } \\
\text { F-statistic } \\
\text { P-value }\end{array}$ & $\begin{array}{c}288,912 \\
0.041 \\
0.079 \\
233,047 \\
15.470 \\
0.000\end{array}$ & $\begin{array}{c}287,443 \\
0.076 \\
0.079 \\
231,881 \\
14.402 \\
0.000\end{array}$ & $\begin{array}{c}287,443 \\
0.023 \\
0.079 \\
231,881 \\
2.368 \\
0.050\end{array}$ & $\begin{array}{c}288,912 \\
0.037 \\
0.171 \\
233,047 \\
24.920 \\
0.000\end{array}$ & $\begin{array}{c}287,443 \\
0.067 \\
0.171 \\
231,881 \\
22.077 \\
0.000\end{array}$ & $\begin{array}{c}287,443 \\
0.023 \\
0.171 \\
231,881 \\
4.495 \\
0.001\end{array}$ \\
\hline
\end{tabular}

Notes: All regressions include dummy variables for child's age at end of sample in quarters. Other included controls: other race, mother smoked during pregnancy, mother's education (in years: $0-11,12,13-16,16+)$, mother's age $(<20,20-24,25-$ 29, 30-34, 35+), mother married at birth, sex, birth order $(1,2,3,4+)$, multiple birth indicator, indicator for other race (non-white, non-black), and indicator for child ever used public insurance; zip code level variables: population, population density, median age, average household size, pct. with less than high school $(25+)$, pct. with bachelor's degree or more $(25+)$, pct. in labor force $(16+)$, pct. of households making $<20 \mathrm{k}$, pct. of households making $>200 \mathrm{k}$, median year structure built, pct. of housing owner occupied, pct. of housing vacant, median value of owner occupied housing, pct. of families below poverty. F-statistic/P-value from a test that the coefficients on the first 4 birthweight bins interacted with black are jointly equal to zero. Standard errors clustered at mother. The omitted categories are 3000-3499 and 3000-3499* black. 


\section{Table A.10: Asthma and Low Birthweight: Triple Difference}

\begin{tabular}{lcc}
\hline & $\begin{array}{c}\text { Ever Diagnosed with Asthma } \\
(1)\end{array}$ & $\begin{array}{c}\text { No. Times Diagnosed with Asthma } \\
(2)\end{array}$ \\
\hline Black & $0.045^{* * *}$ & $0.120^{* * *}$ \\
& $(0.002)$ & $(0.008)$ \\
Low birth weight $(<2500 \mathrm{~g})$ & $0.034^{* * *}$ & $\left(0.005^{* * *}\right.$ \\
& $(0.002)$ & $0.011^{* *}$ \\
Black zip & $0.009^{* * *}$ & $(0.005)$ \\
& $(0.002)$ & $0.139^{* * *}$ \\
Black * Low birth weight $(<2500 \mathrm{~g})$ & $0.034^{* * *}$ & $(0.031)$ \\
& $(0.008)$ & 0.007 \\
Black * Black zip & -0.002 & $(0.011)$ \\
& $(0.003)$ & $0.142^{* * *}$ \\
Low birth weight $(<2500 \mathrm{~g}) *$ Black zip & $0.029^{* * *}$ & $(0.028)$ \\
Black * Low birth weight $(<2500 \mathrm{~g}) *$ Black zip & $(0.006)$ & -0.040 \\
& -0.016 & $(0.050)$ \\
Individual/census vars & $(0.011)$ & $\mathrm{x}$ \\
Hospital fixed effects & $\mathrm{x}$ & $\mathrm{x}$ \\
\hline Observations & $\mathrm{x}$ & 446,152 \\
R-squared & 446,152 & 0.054 \\
Mean dep. var. & 0.064 & 0.179 \\
Clusters & 0.084 & 368,295 \\
F-statistic & 368,295 & 20.394 \\
P-value & 20.223 & 0.000 \\
\hline
\end{tabular}

Notes: All regressions include dummy variables for child's age at end of sample in quarters. Other included controls: other race, mother smoked during pregnancy, mother's education (in years: $0-11,12,13-16,16+)$, mother's age $(<20$, 20-24, 25-29, 30-34, 35+), mother married at birth, sex, birth order (1, 2, 3, 4+), multiple birth indicator, indicator for other race (non-white, non-black), and indicator for child ever used public insurance; zip code level variables: population, population density, median age, average household size, pct. with less than high school $(25+)$, pct. with bachelor's degree or more $(25+)$, pct. in labor force $(16+)$, pct. of households making $<20 \mathrm{k}$, pct. of households making $>200 \mathrm{k}$, median year structure built, pct. of housing owner occupied, pct. of housing vacant, median value of owner occupied housing, pct. of families below poverty. F-statistic/P-value from a test that the coefficients on the first 4 birthweight bins interacted with black are jointly equal to zero. Standard errors clustered at mother. 
Table A.11: Asthma and Low Birthweight: Movers

\begin{tabular}{|c|c|c|c|c|c|c|}
\hline & \multicolumn{3}{|c|}{ Ever Diagnosed with Asthma } & \multicolumn{3}{|c|}{ No. Times Diagnosed with Asthma } \\
\hline & $\begin{array}{c}(1) \\
\text { All Mothers }\end{array}$ & Black Mothers & $\begin{array}{c}(3) \\
\text { Other Mothers }\end{array}$ & $\begin{array}{c}(4) \\
\text { All Mothers }\end{array}$ & $\begin{array}{c}(5) \\
\text { Black Mothers }\end{array}$ & $\begin{array}{l}(6) \\
\text { Other Mothers }\end{array}$ \\
\hline $500-999$ & $0.189 * *$ & $0.239 * *$ & 0.153 & 0.157 & 0.271 & -0.024 \\
\hline & $(0.095)$ & $(0.100)$ & $(0.170)$ & $(0.534)$ & $(0.764)$ & $(0.241)$ \\
\hline 1000-1499 & 0.071 & 0.108 & 0.039 & -0.062 & $0.270^{\prime}$ & -0.709 \\
\hline & $(0.087)$ & $(0.117)$ & $(0.116)$ & $(0.334)$ & $(0.251)$ & $(0.803)$ \\
\hline 1500-1999 & 0.029 & 0.100 & -0.044 & $0.247^{\prime}$ & 0.520 & -0.031 \\
\hline & $(0.057)$ & $(0.097)$ & $(0.066)$ & $(0.247)$ & $(0.397)$ & $(0.303)$ \\
\hline 2000-2499 & 0.021 & 0.053 & -0.003 & 0.081 & -0.034 & 0.218 \\
\hline & $(0.031)$ & $(0.052)$ & $(0.037)$ & $(0.147)$ & $(0.150)$ & $(0.228)$ \\
\hline 2500-2999 & -0.002 & -0.007 & -0.007 & 0.059 & 0.124 & 0.014 \\
\hline & $(0.019)$ & $(0.033)$ & $(0.023)$ & $(0.057)$ & $(0.106)$ & $(0.065)$ \\
\hline 3500-3999 & 0.011 & 0.006 & 0.002 & -0.007 & 0.009 & -0.031 \\
\hline & $(0.016)$ & $(0.031)$ & $(0.019)$ & $(0.067)$ & $(0.178)$ & $(0.057)$ \\
\hline $4000-4499$ & -0.008 & -0.051 & 0.013 & 0.094 & -0.131 & 0.173 \\
\hline & $(0.026)$ & $(0.047)$ & $(0.030)$ & $(0.082)$ & $(0.125)$ & $(0.107)$ \\
\hline $4500-4999$ & 0.072 & 0.456 & 0.037 & 0.185 & 0.366 & 0.179 \\
\hline & $(0.068)$ & $(0.318)$ & $(0.064)$ & $(0.179)$ & $(0.444)$ & $(0.190)$ \\
\hline Black zip & -0.016 & -0.005 & -0.024 & -0.062 & -0.059 & -0.046 \\
\hline & $(0.016)$ & $(0.029)$ & $(0.019)$ & $(0.052)$ & $(0.104)$ & $(0.059)$ \\
\hline 500-999* black zip & -0.138 & -0.127 & -0.171 & 0.008 & -0.125 & 0.250 \\
\hline & $(0.127)$ & $(0.143)$ & $(0.229)$ & $(0.590)$ & $(0.829)$ & $(0.380)$ \\
\hline 1000-1499* black zip & 0.079 & 0.096 & 0.073 & 0.190 & -0.210 & 0.833 \\
\hline & $(0.110)$ & $(0.164)$ & $(0.145)$ & $(0.364)$ & $(0.474)$ & $(0.813)$ \\
\hline 1500-1999* black zip & -0.029 & -0.058 & 0.014 & -0.110 & -0.176 & -0.165 \\
\hline & $(0.069)$ & $(0.118)$ & $(0.075)$ & $(0.321)$ & $(0.497)$ & $(0.379)$ \\
\hline 2000-2499* black zip & 0.042 & 0.074 & 0.011 & 0.052 & 0.218 & -0.133 \\
\hline & $(0.044)$ & $(0.072)$ & $(0.056)$ & $(0.191)$ & $(0.249)$ & $(0.278)$ \\
\hline 2500-2999* black zip & 0.023 & 0.034 & 0.034 & -0.001 & -0.114 & $\begin{array}{c}0.115 \\
(0.104)\end{array}$ \\
\hline 3500-3999* black zip & $\begin{array}{l}(0.020) \\
0.005\end{array}$ & $\begin{array}{l}(0.046) \\
0.043\end{array}$ & $\begin{array}{l}(0.031) \\
-0.001\end{array}$ & $\begin{array}{l}(0.080) \\
0.007\end{array}$ & $\begin{array}{l}(0.148) \\
-0.062\end{array}$ & $\begin{array}{l}(0.104) \\
0.046\end{array}$ \\
\hline 年 & $(0.021)$ & $(0.042)$ & $(0.024)$ & $(0.076)$ & $(0.175)$ & $(0.078)$ \\
\hline 4000-4499* black zip & 0.041 & 0.094 & 0.013 & -0.031 & 0.151 & -0.131 \\
\hline & $(0.034)$ & $(0.072)$ & $(0.038)$ & $(0.106)$ & $(0.172)$ & $(0.136)$ \\
\hline 4500-4999* black zip & -0.090 & $-0.553^{*}$ & -0.074 & -0.236 & -0.689 & -0.197 \\
\hline & $(0.103)$ & $(0.324)$ & $(0.115)$ & $(0.229)$ & $(0.486)$ & $(0.256)$ \\
\hline Individual/census vars & $\mathrm{x}$ & $\mathrm{x}$ & $\mathrm{x}$ & $\mathrm{x}$ & $\mathrm{x}$ & $\mathrm{x}$ \\
\hline Hospital fixed effects & $\mathrm{x}$ & $\mathrm{x}$ & $\mathrm{x}$ & $\mathrm{x}$ & $\mathrm{x}$ & $\mathrm{x}$ \\
\hline Mother fixed effects & $\mathrm{x}$ & $\mathrm{x}$ & $\mathrm{x}$ & $\mathrm{x}$ & $\mathrm{x}$ & $\mathrm{x}$ \\
\hline Observations & 8,003 & 2,913 & 5,090 & 8,003 & 2,913 & 5,090 \\
\hline R-squared & 0.072 & 0.127 & 0.092 & 0.051 & 0.110 & 0.067 \\
\hline Mean dep. var. & 0.123 & 0.123 & 0.123 & 0.282 & 0.282 & 0.282 \\
\hline Clusters & 3,568 & 1,279 & 2,289 & 3,568 & 1,279 & 2,289 \\
\hline F-statistic & 0.713 & 0.673 & 0.205 & 0.135 & 0.287 & 0.393 \\
\hline $\mathrm{P}$-value & 0.583 & 0.611 & 0.936 & 0.970 & 0.887 & 0.814 \\
\hline
\end{tabular}

Notes: Other included controls: other race, mother smoked during pregnancy, mother's education (in years: $0-11,12$, 13-16, 16+), mother's age $(<20,20-24,25-29,30-34,35+)$, mother married at birth, sex, birth order $(1,2,3,4+)$, multiple birth indicator, indicator for other race (non-white, non-black), indicator for child ever used public insurance, and dummy variables for child's age at end of sample in quarters; zip code level variables: population, population density, median age, average household size, pct. with less than high school $(25+)$, pct. with bachelor's degree or more $(25+)$, pct. in labor force $(16+)$, pct. of households making $<20 \mathrm{k}$, pct. of households making $>200 \mathrm{k}$, median year structure built, pct. of housing owner occupied, pct. of housing vacant, median value of owner occupied housing, pct. of families below poverty. F-statistic/P-value from a test that the coefficients on the first 4 birthweight bins interacted with black are jointly equal to zero. Standard errors clustered at mother. The omitted categories are 3000-3499 and 3000-3499* black. 
Table A.12: Asthma and Low Birth Weight: by Poverty

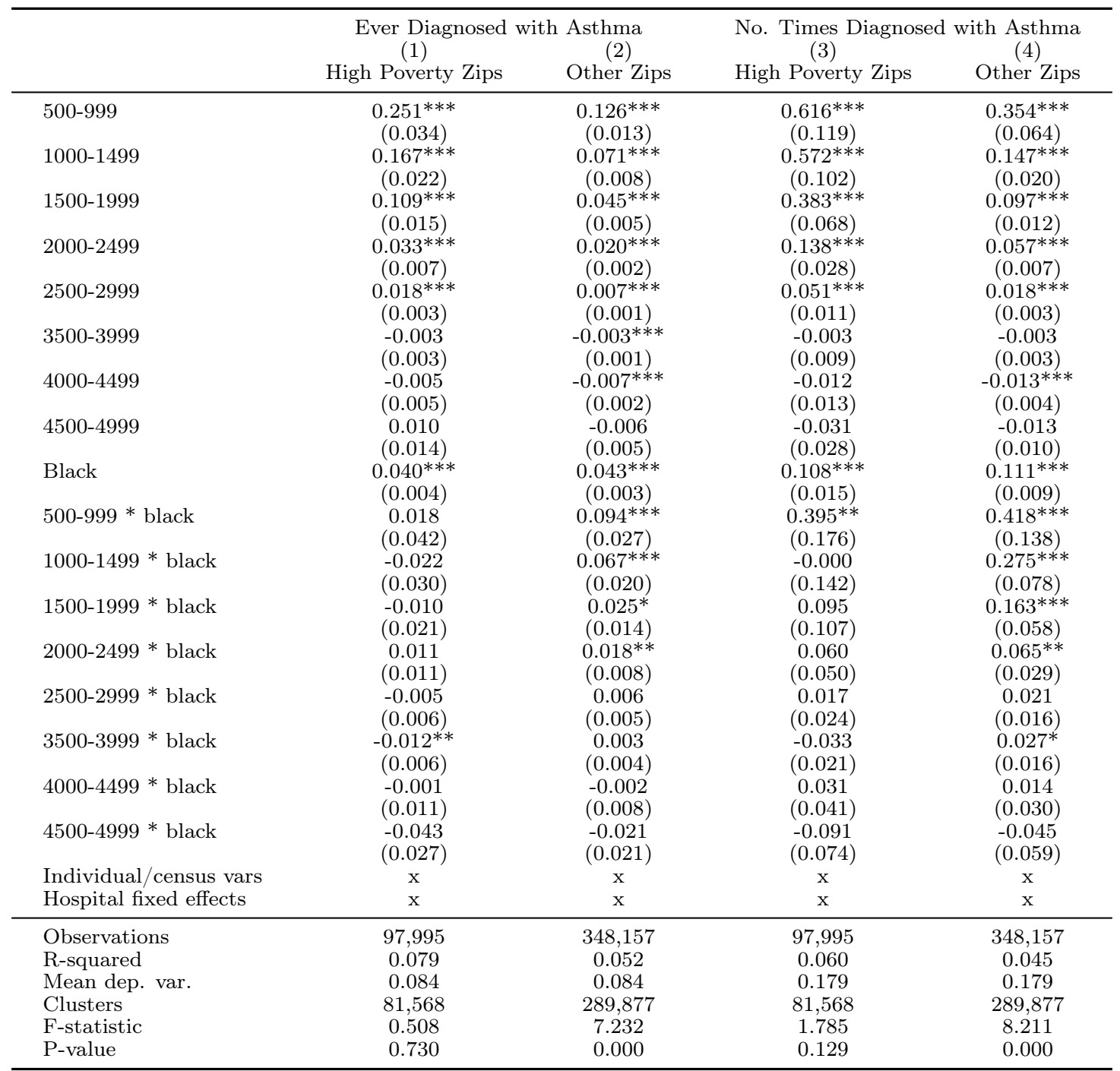

Notes: Other included controls: other race, mother smoked during pregnancy, mother's education (in years: 0-11, $12,13-16,16+)$, mother's age $(<20,20-24,25-29,30-34,35+)$, mother married at birth, sex, birth-3499 order (1, $2,3,4+$ ), multiple birth indicator, indicator for other race (non-white, non-black), indicator for child ever used public insurance, and dummy variables for child's age at end of sample in quarters; zip code level variables: population, population density, median age, average household size, pct. with less than high school $(25+)$, pct. with bachelor's degree or more $(25+)$, pct. in labor force $(16+)$, pct. of households making $<20 \mathrm{k}$, pct. of households making $>200 \mathrm{k}$, median year structure built, pct. of housing owner occupied, pct. of housing vacant, median value of owner occupied housing, pct. of families below poverty. F-statistic/P-value from a test that the coefficients on the first 4 birthweight bins interacted with black are jointly equal to zero. Standard errors clustered at mother. The omitted categories are 3000-3499 and 3000-3499* black. 


\section{Data Appendix}

\section{Information on Coding Medicaid/NJ FamilyCare HMOs}

We categorize the payer information into two groups based on the primary payer: Medicaid, NJ FamilyCare, indigent, and other government (Medicaid, Medicaid HMOs, FamilyCare HMOs, Title XIX Medicaid, other government, and indigent which comes from the "other" category), and private (Commercial, Blue Cross, non Medicaid/FamilyCare HMOs, Champus, and New Jersey State Health Benefits).

The HMO category is broken into Medicaid/FamilyCare and non-Medicaid/FamilyCare HMOs based on information about product lines from New Jersey HMO contracts. Six HMOs with Medicaid/NJ FamilyCare product lines were identified to be in operation during the time period. Four of these HMOs had no commercial product lines, and were easily classified as Medicaid/FamilyCare HMOs. The other two have both Medicaid/FamilyCare and Commercial product lines, and in the data there is no way to distinguish which patients are Medicaid/FamilyCare and which are not. All patients with these HMOs as primary payers were coded as Medicaid/FamilyCare, though some are likely private. The results are robust to whether these patients are coded as Medicaid/FamilyCare or private.

\begin{tabular}{|l|c|c|c|c|c|c|c|c|}
\hline HMO Contracts with Medicaid Product Lines & 06 & 07 & 08 & 09 & 10 & 11 & 12 & Commercial \\
\hline \hline AmeriChoice of NJK/UnitedHealthcare & $\mathrm{x}$ & $\mathrm{x}$ & $\mathrm{x}$ & $\mathrm{x}$ & $\mathrm{x}$ & $\mathrm{x}$ & $\mathrm{x}$ & \\
\hline AMERIGROUP New Jersey/Americaid & $\mathrm{x}$ & $\mathrm{x}$ & $\mathrm{x}$ & $\mathrm{x}$ & $\mathrm{x}$ & $\mathrm{x}$ & $\mathrm{x}$ & \\
\hline Healthfirst Health Plan of New Jersey, Inc & & & & $\mathrm{x}$ & $\mathrm{x}$ & $\mathrm{x}$ & $\mathrm{x}$ & \\
\hline Health Net of New Jersey, Inc. & $\mathrm{x}$ & $\mathrm{x}$ & $\mathrm{x}$ & $\mathrm{x}$ & & & & $\mathrm{x}$ \\
\hline Horizon Healthcare of New Jersey/HMO Blue & $\mathrm{x}$ & $\mathrm{x}$ & $\mathrm{x}$ & $\mathrm{x}$ & $\mathrm{x}$ & $\mathrm{x}$ & $\mathrm{x}$ & $\mathrm{x}$ \\
\hline University Health Plans, Inc. & $\mathrm{x}$ & $\mathrm{x}$ & $\mathrm{x}$ & $\mathrm{x}$ & & & & \\
\hline
\end{tabular}

Commercial refers to a commercial product line. Information on HMO contracts and product lines from the 2006-2012 New Jersey HMO Performance Reports (Report Cards) http://www.state.nj.us/dobi/lifehealthactuarial/hmo2007/index.html 


\section{Information on the String Matching Algorithm}

The matching algorithm creates a patient identifier by finding records with the same date of birth and the same or very similar first and last names. Specifically, the Levenshtein edit distance is used to match names, because of problems with typos and misspellings (stata command strgroup). While it is possible that we are picking up a few cases of different people with the same name and birthday, it does not seem to be a large problem.

The main worry is that there may be many children with similar names and the same birthday, who are being aggregated by the algorithm. In order to assess whether this was a concern, we looked at people with the most common first and last name combinations. We took first and last name combinations that the algorithm assigned to at least eight children, and called this the sample of "common names".

In order to assess the match quality, we looked at the three-digit zip code of residence reported for each visit. Of this sample of children with extremely common names, those with more than ten visits reported all visits in the same three-digit zip code. This suggests that the algorithm did not mistakenly aggregate people with common first and last name combinations - otherwise we would expect the people with common name combinations and many visits to report multiple zip codes. Of all people with these common names, $92.49 \%$ reported just one three-digit zip, $6.94 \%$ reported two, and $0.58 \%$ reported three.

Furthermore, we manually inspected all patients in the top $1 \%$ of number of visits. None of these children had "common names", as defined above, and almost all reported either just one three-digit zip code, or a combination of neighboring three digit zip codes. 